\title{
WestVirginiaUniversity
}

THE RESEARCH REPOSITORY @ WVU

Graduate Theses, Dissertations, and Problem Reports

2011

\section{Contests over pastoralism in the southern Sahara and northern Sahel}

\author{
Franklin Charles Graham IV \\ West Virginia University
}

Follow this and additional works at: https://researchrepository.wvu.edu/etd

\section{Recommended Citation}

Graham, Franklin Charles IV, "Contests over pastoralism in the southern Sahara and northern Sahel" (2011). Graduate Theses, Dissertations, and Problem Reports. 3363.

https://researchrepository.wvu.edu/etd/3363

This Dissertation is protected by copyright and/or related rights. It has been brought to you by the The Research Repository @ WVU with permission from the rights-holder(s). You are free to use this Dissertation in any way that is permitted by the copyright and related rights legislation that applies to your use. For other uses you must obtain permission from the rights-holder(s) directly, unless additional rights are indicated by a Creative Commons license in the record and/ or on the work itself. This Dissertation has been accepted for inclusion in WVU Graduate Theses, Dissertations, and Problem Reports collection by an authorized administrator of The Research Repository @ WVU.

For more information, please contact researchrepository@mail.wvu.edu. 
Contests over pastoralism in the southern Sahara and northern Sahel

\title{
Franklin Charles Graham IV
}

\author{
Dissertation submitted to the \\ Eberly College of Arts and Sciences \\ In partial fulfillment of the requirements \\ for the degree of \\ Doctor of Philosophy \\ in \\ Geography \\ Brent McCusker, Ph.D., Chair \\ Jennifer Miller, Ph.D. \\ Jeremy Njeru, Ph.D. \\ Timothy Warner, Ph.D. \\ Daniel Weiner, Ph.D. \\ Department of Geology and Geography \\ Morgantown, West Virginia \\ 2011
}

Keywords: Pastoral Groups; Fragmentation; Development; Arab;

Tuareg (Kel Tamasheq); Toubou

Copywright 2011 Franklin Charles Graham IV 


\section{ABSTRACT \\ Contests over Pastoralism in the southern Sahara and northern Sahel Franklin Charles Graham IV}

West African pastoral groups (Arab, Tuareg, Toubou, and Fulani) experience contests both within their society, and, with outside agents regarding state integration, land use and development. Pastoral leadership, neighboring sedentary groups, national governments, multinational corporations, aid organizations, and academia all influence the paths pastoralists take in their relationship with the environment, the markets they return to, the animals the shepherd, and the non-pastoral opportunities they pursue, to name a few. The social relations that exist between pastoralists and outsiders can essentially coalesce or break apart pastoral society, depending on the actions taken by the various actors mentioned. The outcomes of pastoral fragmentation have various consequences on the region's ecology, economy and security.

The conflicts that fragment pastoralists and the actions they take to reconfigure their society are the central themes of this dissertation. The interplay between climatic crises, the increasing imposition of external controls, and a constant shrinking of a disputed commons brings pastoralists into conflict with outsiders and, with each other. The first part of this dissertation outlines, from colonial times to present, the relations pastoral groups have experienced with colonial powers, African independence leaders, aid workers, and now Western militaries and terrorists. The second part looks within Arab, Tuareg, Toubou, and Fulani society to understand the fluidity in which pastoralists move back and forth between herding and non-herding activities to maintain social cohesion and identity as pastoralists. The final part is an exploratory remote sensing investigation of the customary pastures of the Tuareg groups in north-eastern Mali. Observations in this vegetation change detection study indicate a spatial differentiation between resources near the Niger River and those in more remote, drier regions of the study area. The changing relations of outside actors, the strategies taken by pastoralists to maintain their identity, and the changing dynamics of natural resources sometimes subtly, other times dramatically, fragments pastoral society. Yet, pastoralists continue to reconfigure, rebound and maintain resilience despite the changes among and, around them. 


\section{DEDICATION}

This work is dedicated to the nomadic and sedentary communities of Iferouāne, Assodé, Gougaram, Tîmia, Aguelal, Nguigmi, Ngourti, Agadem, and others in the northern and eastern regions of Niger who I met but was not allowed to interview because of the 2007-2009 Rebellion. Your stories, though unheard for the moment, are worth telling and will be sought out by other researchers and myself when the situation resolves. 


\section{ACKNOWLEDGEMENTS}

I would like to thank the local Arab and Kel Tamasheq (Tuareg) communities of Gao and Ménaka, Mali for their willingness to share their challenges and hospitality bestowed to me during my visits in 2006-2008. Financial support comes from the National Science Foundation's DDRI grant (No. 0622892). Other support comes from the Eberly Arts and Sciences College and the Department of Geology and Geography both at West Virginia University. I would also like to thank the West Virginia GIS Tech Center for their technical support in 2006-2009. Finally, much thanks must be given to Dr. Brent McCusker and Dr. Timothy Warner at West Virginia University, and my father, Frank Graham of Mendocino County, California, for their editing help during the dissertation process. Any errors or oversights are strictly my own. 


\section{TABLE OF CONTENTS}

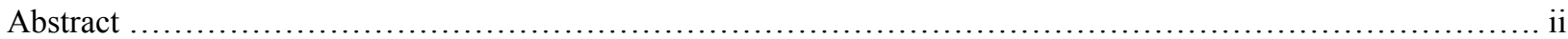

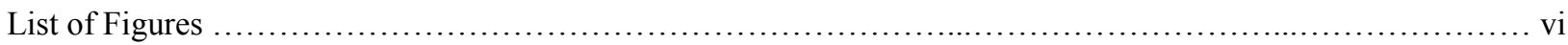

Chapter 1: Introduction, Finding Honorable Paths for Customary Pastoral Groups in the Sahara and Sahel .......... 2

Chapter 2: The Bowl is Broken, Pastoral Resilience to Development and State Integration in West Africa ........... 6

Chapter 3: We Eat with Different Spoons These Days, The Maintenance of Pastoralism as a Social Formation in the

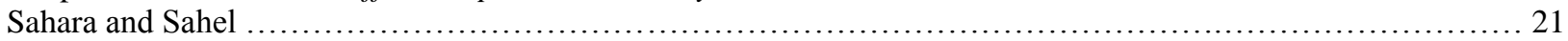

Chapter 4: Quantitative vegetation changes in north-eastern Mali Using Local Knowledge and Landsat TM Imagery,

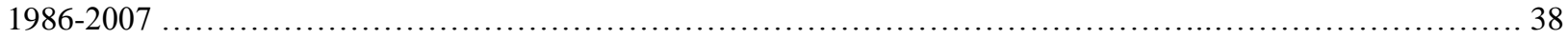

Chapter 5: Conclusion, No Direction is Certain until the Path is Walked, Pastoralists and their future in the Sahara

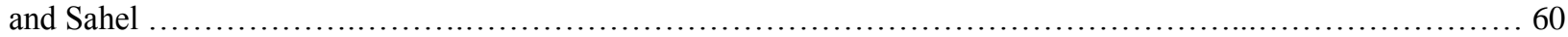

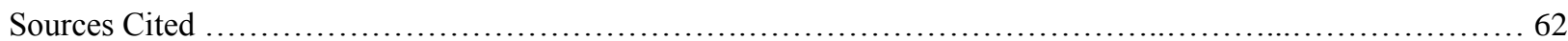




\section{LIST OF FIGURES}

Figure 01: Photo of Two Kel Tamasheq Men Crouching at Encampment …................................ 1

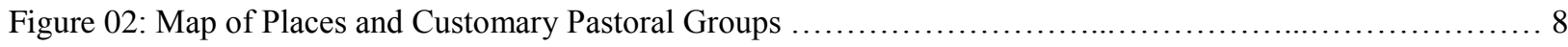

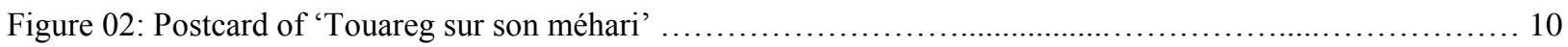

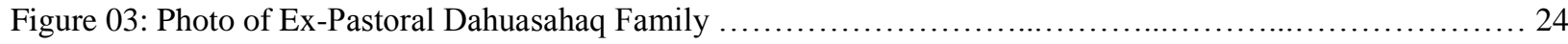

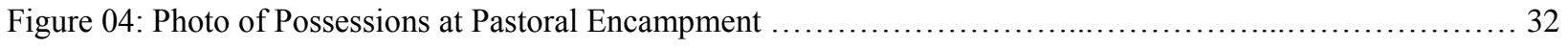

Figure 05: Table of Vegetation and Kel Tamasheq Corresponding Place Names .............................. 41

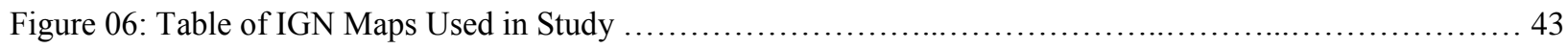

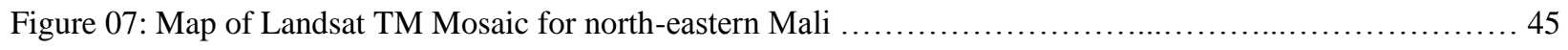

Figure 08: Table of 4 Meteorological Stations in north-eastern Mali .......................................... 46

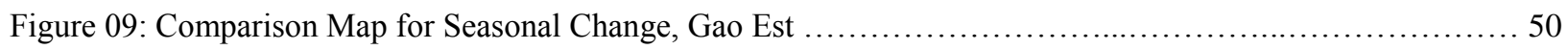

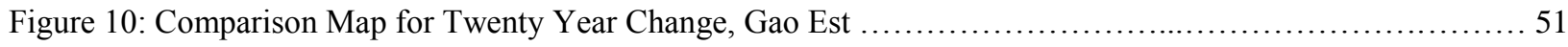

Figure 11: Comparison Map for Seasonal Change, Telataï and Tidarmène ...................................... 55

Figure 12: Comparison Map for Twenty Year Change, Telataï and Tidarmène ............................... 56 
Figure 01 : Photo of Two Kel Tamasheq Men Crouching at an Encampment

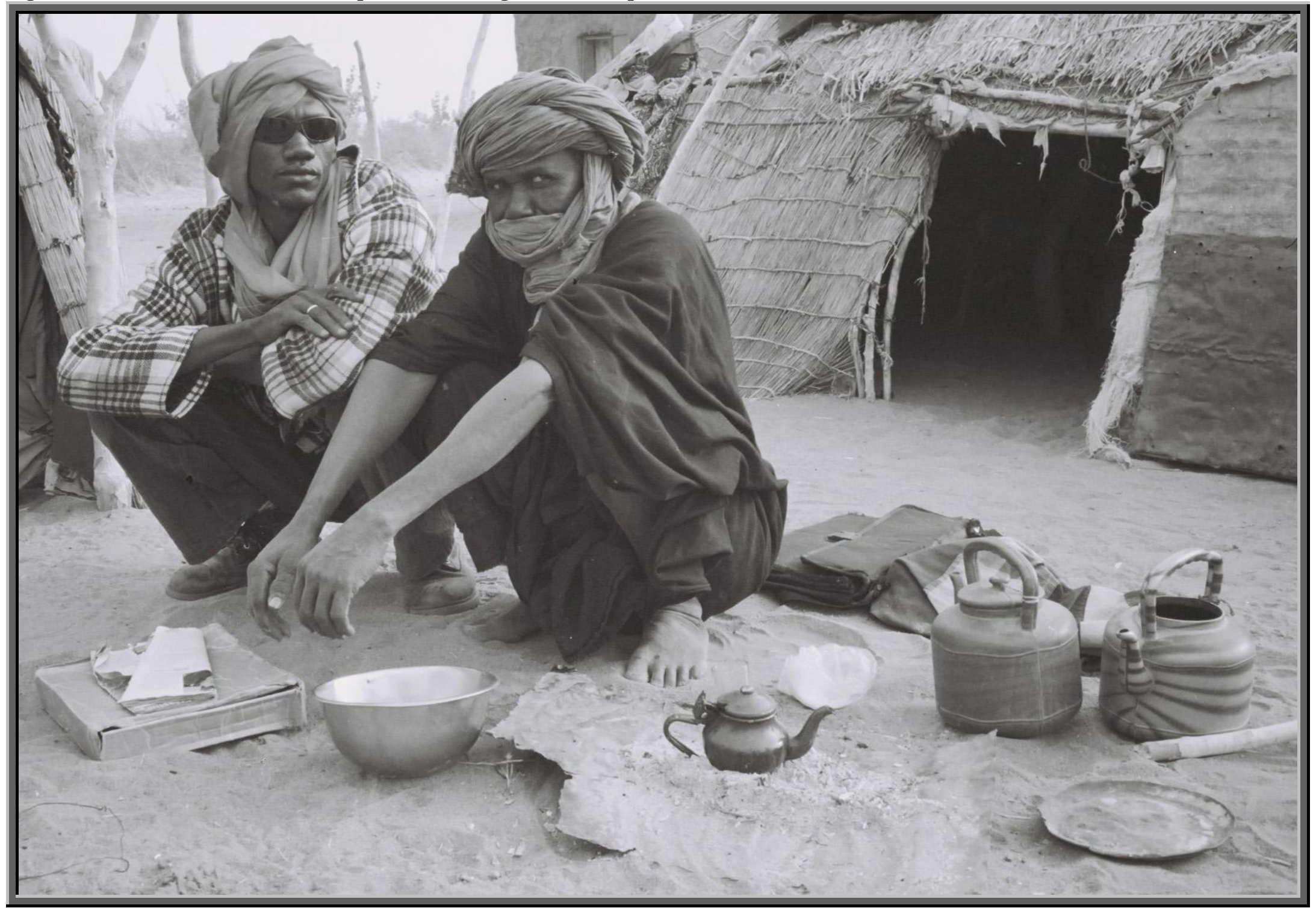

Source: Taken by author in January 2007 at Sosso Koïra quarter of Gao, Mali. 


\section{Chapter 1: Introduction \\ Finding Honorable Paths for Customary Pastoral Groups in the Sahara and Sahel}

In December 2007 during the approaching Islamic festival of Eid al-Adha in Niger, it was difficult for recent arrivals to know the abundance of pasture in the northern Aïr Region (CILSS, Juin/Juillet 2007; FEWS, August 2007). Local pastoralists knew. Those possessing sheep and goats did their best to fatten their animals through grazing and sell them, profiting from the holiday's high demand and return for ruminants. They were, however, disappointed to see prices reduced due to the influx of many seeking to liquefy stocks. Others who chose not to sell their animals moved either to urban centers or South, bypassing the exploitation of the abundant pastures surrounding them. The imaginary administrative boundary that separates the Agadez and Zinder Regions became a physical one as Tuareg tents and Fulani huts lined the northern limit of Zinder's administrative zone. Agadez and Arlit swelled with villagers from Goûgaram, El Méki and Assodé. Generally speaking, Aïr’s countryside was abandoned.

When Boubaker Ag Ghali, a middle-aged Kel Tamasheq man from Iferouâne and member of a local NGO (non-governmental organization) is asked about his village he sharply replies, "They are here in Arlit! Iferouâne is occupied only by the military these days." Since February 2007, the Niger government increased military operations around Agadez in opposition to the politico-military group, Le Mouvement des Nigériens pour la Justice, or MNJ. The MNJ has engaged in combat with the Nigérien army, attacked infrastructure related to uranium mines in the region, and abducted local authorities and mine employees (African Research Bulletin, 2008; Polgreen, 14 December 2008). The reasons for the revolt are complex (see Guichaoua, 2009) but the overall effect has been debilitating on local people. Pastoralists and farmers could not remain in the countryside or villages without risk of losing their lives and property (Amnesty International, 19 December 2007 and 3 April 2008). Even those not dependent on the exploitation of natural resources such as merchants and tour guides experienced a sharp drop in business. Shipments declined due to regulations placed on transport and from individual truckers choosing safer routes for their trucks and cargo (Author Interviews, December 2007a and c). Even if Arlit and Agadez merchants had stocked shelves their clients lacked the purchasing power they held before the rebellion. Tourism, which experienced a slow decline in the 1990s, has plummeted from both the rebellion and the escalation of the Global War on Terror (GWOT) since 2001 (Walther and Retaillé, 2010). In short, many are affected when there is civil unrest.

Ag Ghali avoids talking about the rebellion. Niamey has barred foreign journalists from the region and jailed local ones for contact with the MNJ (Reporters without Borders, 31 October 2007 and 15 January 2008). He becomes nostalgic looking at photos from a Kel Tamasheq cultural celebration that took place in Iferouâne last year. Into the interview, Ag Ghali shares his vision of development for communities in the Aïr Region. "People need a plot of land to construct a home, farm and raise animals. With a motor pump, fencing, five animals and a seed bank they can feed their families and live well." When mention is made of restocking the herds of nomadic herders, the livelihood most common before the 1970s, Ag Ghali smirks. "Those days are over!" he declares. "The pasture isn't

\footnotetext{
${ }^{1}$ Known as the 'Tuareg' and 'Bella' in English, Kel Tamasheq is an encompassing term for the noble and vassal groups that speak the Tamasheq language.
} 
there anymore." Even when shown reports and satellite imagery of the recent abundance of vegetation growth in the region during the past few years Ag Ghali holds steadfast, "The pasture isn't there anymore, at least ... not for us."

$\mathrm{Ag}$ Ghali is predicting sedentarization as inevitable for herders in the Aïr Region, a trend that has occurred since the famines of the 1970s and 1980s, and 1990s rebellion. It is well documented the pressures pastoralists experienced regarding displacement, urbanization, shifts into other employment, and wealth redistribution (Starr, 1987; Jacks, 1994; Turner, 2000; Claudot-Hawad, 2001). Ag Ghali, an educated and steadily employed man, sees the path of development for the Kel Tamasheq as agropastoralism, where each family owns a plot of land to farm on and raise a small stock of animals. His vision is similar to other African development schemes that looked to transform pastoral commons to private property with varying results (Oxby, 1985; Little, 1996; Angassa and Oba, 2008). For Ag Ghali, the distribution of the items and land rights, if implemented, are meant to empower and protect local communities in the Aïr Region. Such steps, from Ag Ghali's perspective, will also integrate the northern communities, who have a history of grievances with central authority, into the Niger state.

There are two concerns with Ag Ghali's vision, however. One is the concern over what consequences such a plan has on the local ecology. Some groups in the region do rely on agropastoralism as their principle socioeconomic activity. These groups, however, have limited access to land and water resources and great vulnerability to drought and market downturns. Because of this, they rely on activities unrelated to natural resource exploitation, like migratory labor, commerce and tourism (Bernus, 1981; Spittler, 1993; Grégoire, 2000). To return to some of the specifics $\mathrm{Ag}$ Ghali mentioned, if it was possible to provide all families in the Aïr Region a plot of land and a motor pump, there are likely to be inequities in natural resources like groundwater. Even if adequate resources exist, there still remains the concern of what consequences a more intense land use will have. It is highly unlikely that if all northern Niger families began cultivating the desert that groundwater would recharge sufficiently to maintain such practices.

The other concern affects Ag Ghali's efforts to protect and empower the Kel Tamasheq communities in the Air Region, that is, the enclosing of the commons for a system of private property. At first glance, to provide families with deeds to land sounds attractive given the history of conflict and land right abuses in northern Niger committed by colonial authorities, post-colonial authorities, and pastoralists themselves (Triaud, 1993; Krings, 1995; Claudot-Hawad, 2001). To privatize land, however, introduces a system that is alien to local populations who are accustomed to land access through patronage to families, clans and confederations (Nicolaisen, 1963; Bernus, 1981). This is further complicated by the volatile climate of the region and the static relationship to natural resources people enter when holding title. With the loss of mobility from the privatization and parceling out of the commons, people will have no alternative resources to migrate to, and will either have to weather the crisis or sell off their land and assets, further impoverishing them. In the long term, privatization and the converting of these diverse communities solely to agro-pastoralism is incompatible to both the local ecology and the livelihoods of those inhabiting northern Niger.

This dissertation seeks to express three dominant themes: (1) conflict over pastoral production, (2) fragmentation of pastoralists (articulated through modes of production), and (3) changing relations of humanenvironment interaction. It is based on field data collected during 18 months (October 2006 to March 2008) in West 
Africa and documents from the archives in Aix-en-Provence, France (October 2008 and April 2009). Droughts, market downturns and civil unrest are not the only factors responsible for pastoral disparity, displacement and dispossession for the past 100 years in West Africa. In regards to pastoral groups principally inhabiting Mauritania, Mali, Niger, Chad, and to a lesser degree Burkina Faso, Senegal, Western Sahara, Algeria, and Libya, various actors from French West African officials to the multinational corporations (MNCs) managers; from the colonial tirailleurs coming from Dakar and Algiers to the NGO workers from Europe, North America and Japan contributed greatly to changes occurring in West African pastoral territory. ${ }^{2}$ The intentions of these actors have ranged from malevolent to benevolent with pastoralists viewing all interaction with suspicion. And with good reason too as all outside intervention, despite its intentions, has amplified conflict through the fragmentation of pastoral society and the enclosing of their commons.

The next chapter unravels the dichotomy of pastoral-state relations from colonial and post-colonial; consistencies and inconsistencies; after independence and NGOs; continuities and discontinuities. Pastoral groups from colonial times to the present have been subjected to remote, central government top-down policies respecting land use rights and the structure of political power within their traditional commons. Although pre-colonial forms of power were not ideal, the Arab, Kel Tamasheq, and Toubou groups had control of their own political and resource management within extensive zones of the Sahara and Sahel. ${ }^{3}$ European Colonialism effectively ended such autonomy. It constricted pastoral land use and self-government through imposing arbitrary administrative boundaries, protecting sedentary groups, and emancipating slaves and vassals. Pastoralists sought to evade this colonial experience by continuing their migratory, mobile livelihoods until the droughts and famines of the 1970s and 1980s. Well intentioned external aid efforts further eroded pastoral life by promoting the shift to permanent settlement, menial wage labor, and the erosion of customary leadership practices. Recent efforts are made to reverse such threats to the future of pastoral practices while at the same time integrate pastoralists into the modern state system. From Mauritania to Chad, however, such efforts coincide with ongoing policies of constricting the commons. The advent of the War on Terror, in the name of security needs, has only served to further complicate pastoral-state relations and development schemes. And yet, pastoralists continue to resist policies that undermine their livelihoods, such as limiting access to pasture and water resources within their commons.

The third chapter uses David Harvey's 'six moments' framework to assess fragmentation that has occurred in pastoralists livelihood systems as a result of pastoralists' articulation of modes of production. Despite the fatalistic rhetoric articulated by Western media and some experts, pastoralists have not disappeared. Drought, disease, famines, civil conflicts, theft, and banditry have certainly undermined livelihoods and forced families of Tuareg, Arab, Toubou and Fulani to settle and seek out opportunities that are not compatible with pastoralism, particularly in urban areas. This situation is not necessarily permanent and varies case-by-case and more significantly generationto-generation. Some ex-pastoralists abandoned hopes of restocking their flocks but plan for some of their children to become future pastoralists. In addition despite sedentarization, many retained customary practices of natural

\footnotetext{
${ }^{2}$ Tirailleurs is French for the foot soldiers that came from various parts of the French Empire.

${ }^{3}$ Arab is used for the Moors of Mauritania and other Arabic speakers like the Kounta and Bérabich of Mali and the Shuwa and Mahmid populations of Niger and Chad. Toubou refers to the Tédaga and Dazaga groups of eastern Niger, northern Chad and southern Libya.
} 
resource management, social norms and behaviors and find in the urban areas other pre-capitalist practices that are compatible with their means of everyday tasks and performances. David Harvey's analysis of Marx's six moments to socioeconomic transformation provides an argument as to why pastoralism is not on the decline, whether or not they are tending to herds in the countryside or delivering water house-to-house in the capital.

The fourth chapter explores the use of linking changes in pastoral society to observed changes of quantitative vegetation change through remotely sensed imagery. Change detection studies using remote sensing tell different stories at different scales. Regarding the Sahel, some experts argue over the variability of vegetation cover. Case studies show evidence of desiccation where biophysical and human contributions lead to losses in vegetation and biodiversity. Recent macro scale studies, however, observe a 'greening' in this region, that is, vegetation quantitatively increasing. Through the acquisition of qualitative data indicating vegetation stands used by customary pastoralists, maps produced through aerial missions in the 1950s, and remote sensing data, this study quantifies changes occurring over north-eastern Mali during the 2006-2007 season and long term analysis between 1986 and 2006. The results generated bring new arguments regarding population pressure and human contributions to losses of vegetation cover. In general, vegetation resources in proximity to settled populations were under stress in the seasonal analysis but indicated subtle increases in the long-term comparison. Less accessible vegetation resources in the upper latitudes showed great variability in the long term comparison, some stands declined while others increased. Finally, one hotspot of quantitative vegetation decline was identified for the natural resource base of pastoral communities far removed from the larger populated areas of the Niger River. What the causes are for any of these observations is unknown. The intention here is to identify areas for further investigation through the integration of qualitative methods and remote sensing.

The final chapter gives a brief overview of the challenges pastoralists face with outsider intervention, within their own communities, and in the stewardship of their customary resources. No one path of development is ideal or even just for the diverse interests among pastoralists today. Yet, those in pastoral society demand an honorable path for their families, their clans, and their confederations. Such an honorable path involves pastoral participation in the development of their regions, and the integration of polices and norms that are compatible with pastoral society. Outside actors, whether they are national leaders, NGO workers, multinational corporations, or Western militaries recognize the importance of collaborating with pastoral groups to ensure the region's stability, but they too, through indecision and conflict have not integrated pastoralists into development. The Global War on Terror, at least its current policy and objectives, is further impeding any advancement in state integration and development for pastoral groups. To make the region safe from violent extremism, it is necessary to integrate pastoralists into the governing of the Sahara and northern Sahel, allow regional mobility and autonomy, and local participatory roles in fighting the chronic problems of poverty and fragmentation occurring in pastoral society. An honorable path is what these diverse people seek. 


\section{Chapter Two: The Bowl is Broken Pastoral Resilience to Development and State Integration in West Africa}

"Offer them [pastoralists] to-day in their age of degeneration, some ease of life or luxury as the price of spiritual freedom, and most of them will still refuse." - Rodd et al, 1929

Customary pastoral groups of the Sahara and northern Sahel are habitually depicted as in crisis. The Arab, Kel Tamasheq, and Toubou peoples inhabiting the remote regions of Mauritania, Mali, Algeria, Libya, Niger, and Chad are portrayed by the popular media, policy makers, and academics as victims or as uncompromising belligerents. In the case of victimization the droughts and famines of the 1970s and 1980s are obvious examples. Reporters and policy makers depicted these events as the consequence of overpopulation and poor rangeland practices (Du Bois, 1974; Timberlake, 1985; MacDonald, 1986). Academics also drew similar conclusions (Otterman, 1974; Wade, 1974; Le Houérou, 1977; Eckholm and Brown, 1978; Breman and De Wit, 1983). Although such arguments have become less deterministic in academia, many still conclude that pastoralism as a livelihood is on the decline, that pastoralists remain highly vulnerable to future crises, and those who still possess flocks will gradually sedentarise (Cissé, 1981; Findley et al, 1995; Turner, 1999; Mortimore and Adams, 2001; Bolwig et al, 2009).

Pastoral belligerence, the civil war in Chad 1965-1990, the Western Sahara independence movement, and the rebellions in Mali and Niger during the 1990s and 2000s, are also a return to the crisis narrative. The popular media romanticizes the northern populations in these countries as independent, anti-authoritarian and war-like (Childs and Chelala, 1994; Walker, 2005; Polgreen, 2008). Policy makers and some academics view these communities as 'uncaptured' in terms of development and national integration (Vedeld, 1996; Seely, 2001). GWOT lends no relief as the vastness of the Sahel and Sahara combined with real or perceived threat from terrorists attracts military assistance from the United States and European Union (Antil, 2006; Guichaoua, 2009; Prashad, 2009). African nations like Morocco, Mali and Niger use such military aid to increasingly subjugate their political opponents, in many cases coming from customary pastoral groups (Berschinski, 2007; Graham IV, 2010). Though brief, Mali conducted military operations in and around Tin Zaouetin, near the Algerian Border, in January 2009. Niger committed time and resources to suppress the MNJ Rebellion from 2007-2009 (Guichuaoua, 2009; Thurston, 2010). Even Libya, a non-recipient of GWOT assistance, is suspect of discriminating against pastoral groups in the South (IWGIA, 2006; Zuelch, 12 April 2010). Misunderstandings about why customary pastoral groups arm themselves, kidnap individuals, attack national and foreign interests, and collaborate with extremists creates difficulties for approaches to development and state integration of these remote territories and communities.

Whether viewed as victims or antagonists, the Arab, Kel Tamasheq and Toubou are often misconstrued by outsiders as self-defeating and irrational. For instance in Emnaghuil, Mali, veterinarians found it bizarre that the Chérifan, a Kel Tamasheq fraction, seek government assistance when their flocks are destroyed by drought or disease yet evade paying head taxes or vaccinating their animals in good years (Author Interviews, April 2007a). At military and police stations in Gao, police and soldiers from Bambara, Songhai and Peulh backgrounds co-equate the actions of Arab and Kel Tamasheq insurgents with thieves, murderers and recently terrorists (Author Interviews, March 2007c). A common joke throughout West Africa involves a sick herder in the hospital who needs a lifesaving operation but cannot decide which one of his 300 head of cattle to he must sell to undergo the procedure. He 
ends up dying from his indecision. As small as these examples may seem it is the typical perception that civil servants and NGOs bring to their interactions with pastoral communities.

Arab, Kel Tamasheq and Toubou people are commonly identified as pastoralists although not all tend to animals. Members who do engage in pastoralism as a livelihood require mobility, open access to resources, and periodic work opportunities to stave off the destruction of their flocks (Bourgeot, 1990; Thébaud, 2002). Historically, pastoralists had adapted to environmental and economic variability through their relations with their slaves, their vassals and neighboring sedentary groups to the South (Marty, 1999; Grémont, 2005). Pre-colonial relations between pastoralists and non-pastoralists were not ideal, yet crises were averted or endured by both (Lovejoy, 1978; Galaty and Bonte, 1991). Colonial efforts to co-opt their subjects, however, severed these ties, created conflicts among neighboring groups, and, in their inability to control pastoral territory, promoted animal husbandry until drought returned. It did so in the late 1960s. When this turned to famine for many by the 1970s and was repeated in the 1980s, livelihoods were wiped out pushing large numbers of Arab, Kel Tamasheq and Toubou people to sedentarize, seek out assistance or become menial wage laborers (Azarya, 1996; Burr and Collins, 1999). Pastoralists and non-pastoralists came together in the refugee camps and peripheries of large towns. Young men in particular were in contact with radical elements in Algeria and Libya. Thus, it is no coincidence that rebel officers and recruits come from pastoral and non-pastoral backgrounds in the insurgencies of Western Sahara, Mali, Niger and Chad in the past 40 years (Bonte and Caludot-Hawad, 2000; Lecocq, 2004). It is argued that despite the differences that exist within Arab, Kel Tamasheq and Toubou societies, pastoralism is a nexus, a cultural bond that in addition to language and outsider interference unifies these heterogeneous peoples together periodically, especially when juxtaposed with other African groups (Malkki, 1992; Pelican, 2009).

For over 100 years these three ethnic groups have experienced development policies that applied the "crisis narrative" to justify intervention into their territories (see Figure 01). The establishment and growth of a central state resulted in the enforcement of border restrictions, greater control over natural resources, and competition through agricultural expansion into the drier regions of the Sahel and Sahara (Bourgeot, 1989 and 1990; Grémont, 2005). As a consequence of this, pastoral response to development policies, from European colonialism through the present, has centered on the logic of resilience. That is, Arab, Kel Tamasheq and Toubou respond to policy in ways that do not lessen the connection to their land, their social roles within their societies, and the association of pastoralism as a respectable livelihood and ideal pursuit. When policy became so harsh that resilience was threatened, these groups responded by opting out, Diaspora, or violence. The next section shows how the French and successive independent governments, often under pressure from international development institutions, perpetuated a narrative of crisis. The conclusion from both the archives and interviews shows that interventionist development that utilizes crisis narrative stands to perpetuate misunderstandings regarding the dynamics of pastoral societies and results in continued resistance to anything pastoralists perceive as undermining their ability to cope with the vagaries of their given political, spatial and material ecologies. 
Figure 01: Map of Places and Customary Pastoral Groups; Arab, Kel Tamasheq and Toubou

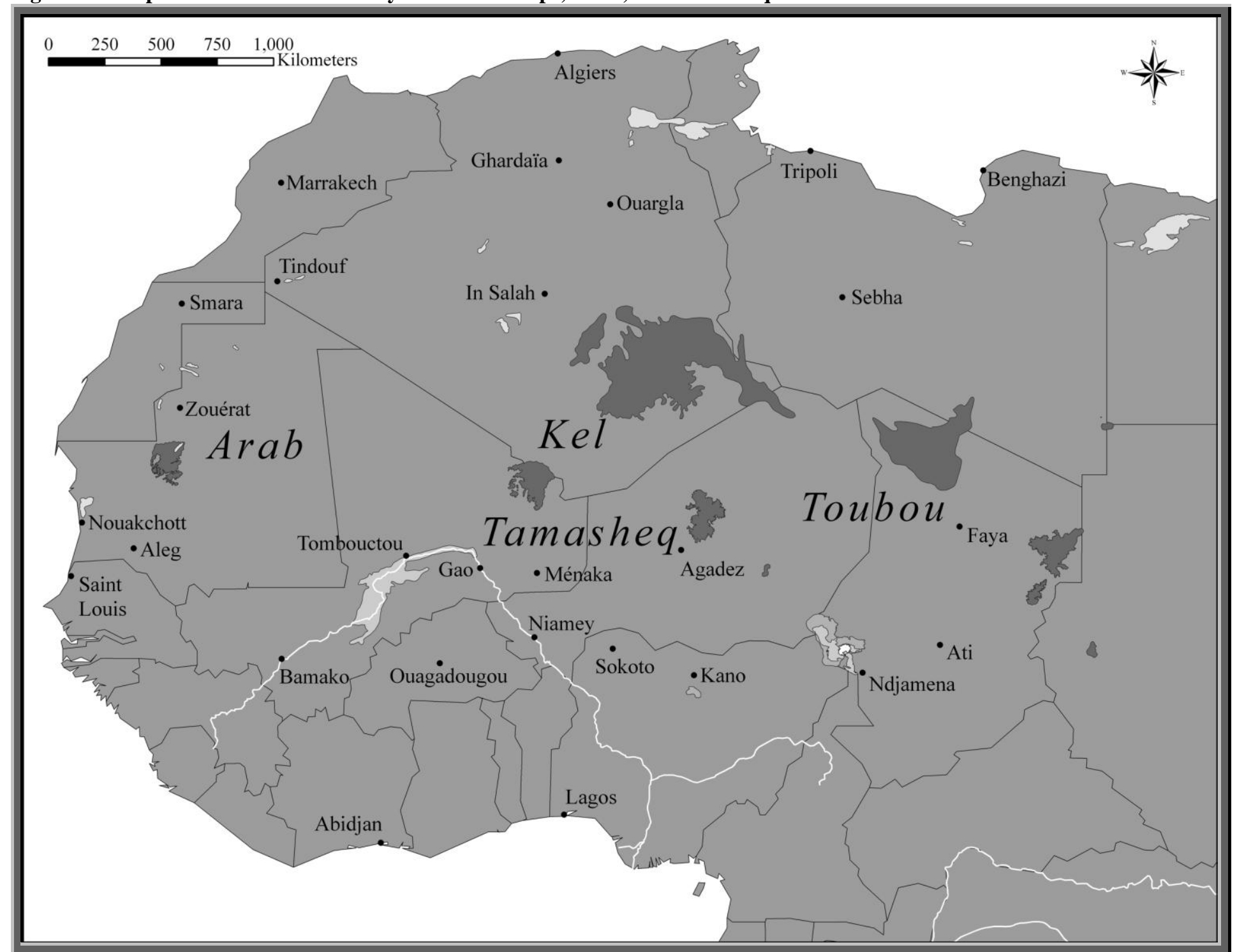

Map created using data from ESRI Data and Maps, version 9.3, (c) 2008. White and light grey areas represent permanent water sources and major floodplains. Dark grey areas represent montane environments where pastoral groups established oases centuries ago. 


\section{The Crisis Narrative}

Arab, Kel Tamasheq and Toubou groups were perceived more as belligerents than victims at the time of European expansion into Africa in the late nineteenth century. The occasional massacre of diplomatic missions in pastoral territory popularized this view and the stories of Europeans killed at the hands of war-like Arab, Kel Tamasheq, and Toubou bands escalated military operations in the remote and drier parts of West Africa (Briggs, 1960; Salifou, 1973; Asher, 2008). Though competition between Europeans encouraged the French to expand into the Sahara and Sahel, the headlines of French officers and tirailleurs killed at the hands of 'treacherous, conniving, murderous dogs' certainly encouraged retaliation and the imposition of French jurisdiction over most of pastoral territory.

Individuals in the colonial service did empathize with the dramatic changes influencing nomadic life. However, these colonial administrators were not without their biases, commonly romanticizing these herders, warriors and slaves in their writings as holdovers from a Medieval Age (Duveyrier, 1864; Hourst, 1898). They disapproved of the use of force in placating pastoral groups and efforts to sedentarize pastoralists (Arnaud and Cortier, 1908; Cortier, 1908). Though they had little influence over policy in the early stages of colonialism, their work influenced the policy of creating reserves years later for Arab, Kel Tamasheq, and Toubou to maintain their customary practices with minimal interference (Galaty and Bonte, 1991; Bernus et al, 1993; Boëtsh et al, 2004).

The West African drought of 1911-14 was the first major incident where pastoral groups were perceived as victims. As drought escalated to famine by 1913 pastoral strategies like raiding and pillaging, requisitioning grain tithes from slaves and vassals, and migrating further South to areas of adequate rainfall were disrupted or dismantled through colonial policy (Richer, 1924; Olivier de Sardan, 1984; Grémont, 2005). As animals died, herders were left with choices of migrating for menial work, rationing out what little food they possessed while struggling to preserve their remaining animals, or in a few places organizing resistance to the 'infidels' that exacerbated this human crisis. Uprisings in northern Niger and eastern Mali coupled with the intrigues and presence of Turk and Sanusiyya agents in the Fezzan and Tibesti Regions created suspicion and alarm of a united front against French rule (Clozel, 7 Juin 1916; Hrany, 1917; Lutaud, 1917; Simon, 28 Février 1919). Despite the fact that most pastoral groups did not rebel against the French, they were once again perceived as aggressive, war-like and subversive during the war.

A romantic image of pastoralists returned after World War I. Various colonial exhibitions in Marseilles and Paris had Saharan pastoral groups on display as nomads maintaining a traditional way of life (Fousset, 22 Avril 1932; Boëtsch et al, 2004, and see Figure 02). General opinion shifted from pacification to preservation (Anonyme, 1937; Calvel, 3 Juillet 1942). Dissent still existed in the ranks of the colonial offices, demanding to sedentarize herders for better control of populations and territory (Hrany, 1917; Lozeray, 1937). Colonial policies, however, concentrated on the larger labor pools and agricultural base South of pastoral territory (Bonnier, 10 Octobre 1912; Brevie, 14 Novembre 1935). In practice, the Sahara and northern Sahel were undermanned and lacked the resources to integrate local populations into the colonial system. These territories were for the most part 'preserved,' and though these zones were smaller than previous pre-colonial orbits exercised before colonialism, their establishment and adequate rains the next few decades allowed nomadic pastoralism to continue (Anonyme, 1937; Salvy et al, 1951). In fact, those engaged in animal husbandry grew in number. Former slaves and individuals from sedentary groups moved into a pastoralism when conditions allowed (Author Interviews, January 2007b and February 2007a). 
Figure 02: Postcard of Touareg sur son Mehari, translated 'A Tuareg on his riding camel.' (Photographer unknown)

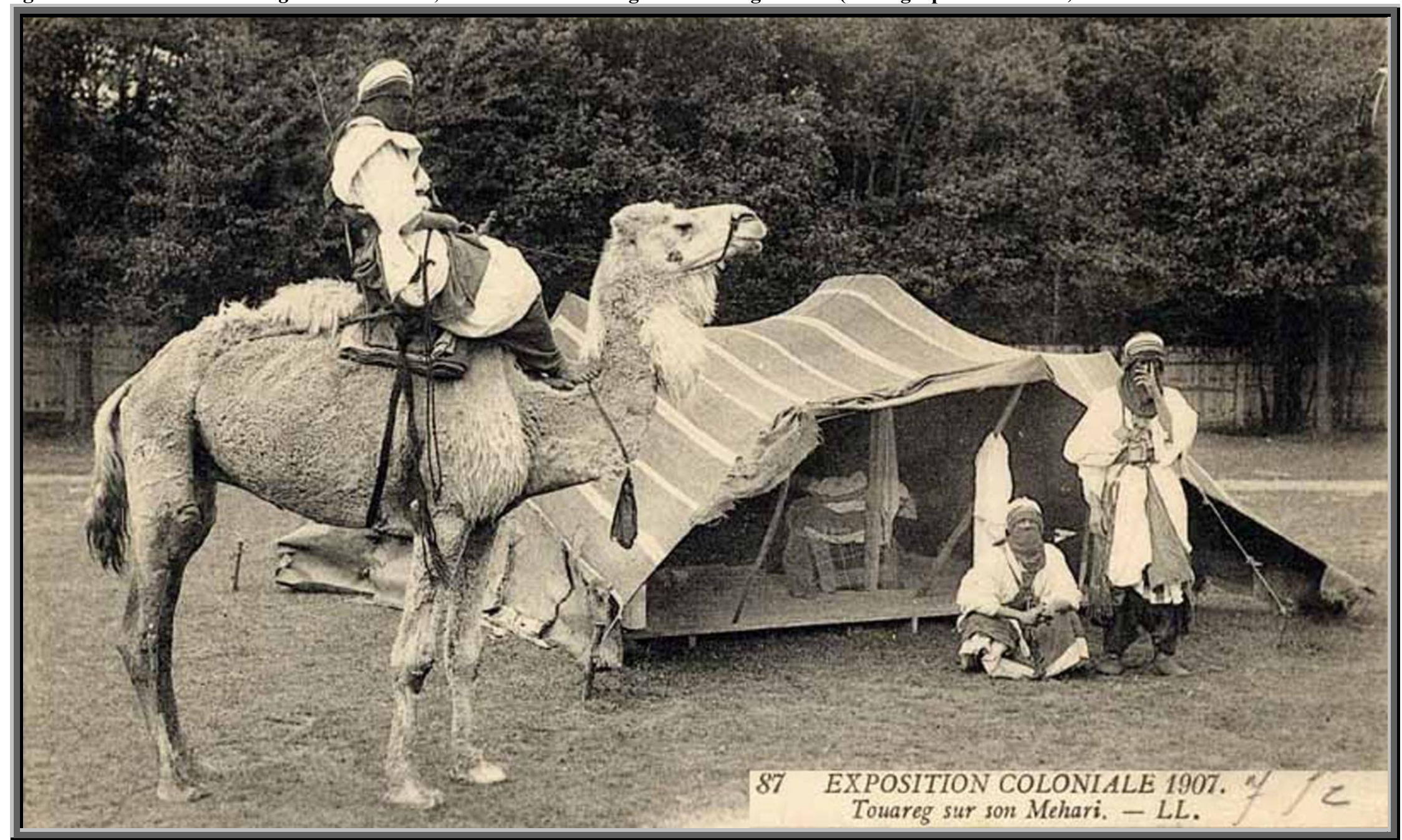

Source: http://en.wikipedia.org/wiki/File:Tuareg_1907.jpg. Accessed on 7 January 2011. 
The theme of pastoralist as victim returned at the end of French rule. A proposal to create the Organisation Commune des Régions Sahariennes (OCRS) in which the northern parts of Mauritania, Mali, Niger, and Chad were to be combined with southern Algeria. Ostensibly, this was intended to give better political representation to Arab, Kel Tamasheq and Toubou groups and relieve them of the dominance from sedentary populations in the Mediterranean and Sahel (Anonyme, 1957; Hama, 1967; Vallet, 1990). Such arguments masked ulterior motives, however. A few French policy makers held concern over future relations with African political movements that were hostile to close ties with their former colonial power. They hoped to form a pro-French state to secure natural gas and oil in Algeria, uranium in Niger, and other natural resources believed in reserve (Boilley, 2004; Sèbe, 2010). The carving out of a Saharan state never materialized, however, because independence leaders maintained close economic relations with France to pursue their development goals (Azarya, 1996; Gammer, 2000). The boundaries remained intact when the French departed in the 1960s and pastoral groups were divided between several states.

Weak to non-existent participation of pastoral groups in the independence movements contributed to an uneasy atmosphere after independence. Pastoralists were minorities yet stewards to large swaths of territory in Mali, Niger, Chad, the Western Sahara, and Algeria. Only in Mauritania did close ties between pastoral groups and national leaders exist (Bonte and Caludot-Hawad, 2000; Bonte, 2001). Their partnership with Morocco in occupying the Western Sahara after the Spanish withdrew in 1975, however, exacerbated tensions with the Reguibat, Arabicspeaking camel herders inhabiting western Algeria, northern Mauritania and the Western Sahara. The Reguibat became prominent in the Polisario, a politico-military movement fighting for Western Saharan independence for over thirty years (Beslay, 1985; Mundy, 2007). In Mali, pastoral-state tensions developed into violence early on in the Adrar des Ifoghas over Bamako's efforts to control natural resources, conduct mineral exploration, and attempts to dismantle the chieftainship system (see Imposition of Central Authority below). The specter of pastoralists as belligerents resurfaced. Bamako labeled the rebels as subversive, backward and enemies to Mali's future (Boilley, 1999; Berge, 2001). Chad experienced greater fragmentation as protests from both sedentary and nomadic peoples escalated into civil war by 1965. Many Chadians were agitated with the corruption and favoritism extended to Sara peoples by François Tombalbaye's rule (Burr and Collins, 1999; Walker, 2005). As the fighting persisted, however, conflict widened from anti-government sentiment to rivalries between sedentary and nomadic groups. Toubou and Arab groups were well-armed, organized and winning battles. Though these two ethnicities represent less than $10 \%$ of Chad's population, their military successes during the internecine violence allowed leaders to gain national offices, a development that exacerbates the northern-southern rivalry today (Buijtenhuijs, 2001; Solé-Arqués, 2009).

Droughts in the 1970 s and 1980 s revived the victimization narrative. Herders were highly vulnerable as their flocks became emaciated. When the drought intensified, the restrictions placed on herders through border closures and changes in natural resource management left little maneuverability. Access to water and pastures became invaluable for survival. Nomads competed with each other and sedentary groups for natural resources with some incidents turning to violence, including clashes at the Senegal-Mauritania border and eastern Niger in the late 1980s (Thébaud, 2002; MacEwen, 2010). Those far from agricultural zones foraged wild foods for their families' meals and pruned trees to feed their herds (Author Interviews, January 2007c and February 2007b). Such activities 
were blamed for a changing climate. Garret Hardin's 'tragedy of the commons' thesis combined with other works like Joesph Otterman's study of animals' grazing habits changing albedo (surface reflectance) were used by policy makers and reporters to portray pastoralists as degrading the land and influencing climatic change through overstocking and overgrazing (Hardin, 1968; Otterman, 1974). It is now understood that socioeconomic controls over herd size and access to natural resources had been and remain in place (Behnke et al, 1993; Berge, 2001), but reporting at the time assumed otherwise (Du Bois, 1974; MacDonald, 1986).

The Malian and Nigerien Rebellions in the 1990s brought back romantic and militant images of pastoral groups. The foreign press depicted a people stripped from their only means of subsistence and fighting for greater control of their lands (Shipton, 1990; Childs and Chelala, 1994). Rebel groups equipped themselves from the arms markets produced by conflicts in the Western Sahara and Chad (Burr and Collins, 1999; San Martín, 2004). What the objectives were of the various rebel groups of 1990-1997 is too diverse and complex to explain here but what was evident were the large numbers of Arab, Taureg and Toubou among the rebels. Dissatisfaction with Bamako and Niamey was evident not only among these groups but also in the populous South as autocratic regimes were deposed and quickly replaced by democratic ones in 1991 (Krings, 1995; Seely, 2001). The following year some rebels capitulated to the new regimes but others did not. Sedentary communities did not understand the persistence of violence in the North and reacted to the delays in the peace process. Antagonisms were not limited to the press. In Mali local militias, particularly the Gandakoï, in the Gao and Tombouctou Regions organized and attacked Arabs and Kel Tamasheq, regardless of their participation or abstention in the rebellion. Hundreds were killed or fled the commune of Léré in May 1991 (Randall, 2005). Mali’s new government had difficulty diffusing both rebel violence in the countryside and the vigilantism in the towns. Property was destroyed, individuals assaulted, killed, and children were rounded up and drowned in the Niger River (Author Interviews, May 2007).

\section{Imposition of Central Authority}

Before the coming of Europeans, customary pastoral groups had an active role in their governance. Their rule was decentralized and expansionist, taking advantage of natural resources in the desert during the height of the rainy season and gradually shifting to permanent water sources as the dry season approached. Arab, Kel Tamasheq, and Toubou raided and pillaged at times from need and in some cases for gain, but it should be noted that such actions were rare (Arnaud and Cortier, 1908; Le Rouvreur, 1962; Claudot-Hawad, 1990). It was understood that too much violence interrupted cereal production and had the likely consequence of famine. The Oulliminden, a fraction of the Kel Tamasheq, have the proverb, "Our irezz aodem akus wa der'itett," ('We do not break the bowl from which we eat' (Hourst, 1898)). Thus pastoralists' relationship with agriculturalists varied from requisitioning grains and other produce from slaves and vassals, to tithes or payments for protection from aggressors and to negotiation, or in rare cases, raids against villages and camps that refused compliance (Conte, 1991; Pandolfi, 1998; Grémont, 2005).

European arrival transformed governance in the Sahara and northern Sahel. The French obtained most of the territory, with the Italians, Spanish and English holding smaller possessions and influence for the regions. In general, resistance to colonial rule was intermittent and isolated but when it occurred, Europeans needed to collaborate with other Africans or other colonial powers to suppress it (Frémeaux, 1993; Triaud, 1993). They used 
draconian tactics and commonly pitted one group against another (De Salins, 15 Juin 1912; Dimpault, 10 Février 1923). The revolts during World War I were the largest in scale, although this was neither the start nor conclusion of anti-colonial uprisings. The Kel Ahaggar, a Tamasheq fraction inhabiting the central Sahara, showed resistance to French intrusion as early as 1880 and the Reguibat, organized against Spanish rule as late as 1934 (San Martín, 2004; Asher, 2008). The First World War, however, entrenched the antagonisms between various African groups, both sedentary and nomad. Two examples from Francophone Africa include the Songhai and Peulh aiding against the Oudalan Tamasheq in the Upper Volta, and the Chaâmba, an Algerian Arab fraction that assisted the French take back Agadez from the Kel Aïr, the Tamasheq confederation of northern Niger (Bourcade, Mai et Juin 1916; Carde, 29 Juin 1917). ${ }^{4}$ The rebels, both during the conflicts and after defeat, raided villages and neighboring pastoral groups for survival. Villages from Lake Chad to the banks of the Niger River experienced numerous attacks from nomadic groups and caravan routes, like the Arab Bérabich in northern Mali, were susceptible to pillaging bands (Anonyme, 1917; Simon, 28 Février 1919; Dimpault, 10 Février 1923).

After World War I, European authority trickled into customary pastoral society through chiefs appointed by the colonial service. These agents were responsible for collecting head taxes on camels and cattle. They became the guardians and fee collectors at newly-constructed cement wells. They were also the truant officers enrolling children in the schools and enlisting young, able-bodied men for work projects (Nicholas, 1950; Clauzel, 1962; Le Rouvreur, 1962). A chieftainship system, though imposed, was foreign to pastoralists and difficult to carry out effectively due to the poor financing and lack of attention prominent officials paid to pastoral territory (Bonnier, 10 Octobre 1912; Teuasson, 20 Février 1926; Brevie, 14 Novembre 1935). In addition, chiefs often favored relations with neighboring encampments more than the bureaucrats residing at colonial posts. Some individuals certainly profited from their position of power. This, however, was often the exception to the rule considering colonial officials from Algiers to St. Louis to Fort Lamy were far removed from pastoral society (Bourgeot, 1989; Spittler, 1993; Pandolfi, 1998). ${ }^{5}$ Chiefs often negotiated or neglected their colonial responsibilities for the loyalty of their constituents. Pastoral integration into a centralized colonial system remained weak to non-existent because of this.

The ascent of African nationalist movements in the 1960s brought dramatic changes to pastoral territory. The Europeans were leaving, the idea of an OCRS state was not feasible, and Saharan peoples particularly those under the jurisdiction of Bamako, Niamey and Ndjamena, were concerned over national leaders' plans to modernize. Their rhetoric included rapid industrialization, the expansion of agriculture, and mineral exploration. No matter how well-intentioned these programs were, they interfered with customary pastoral society. Some changes occurred without confrontation. In northern Mauritania, nomadic Reguibat clans were displaced by mining operations around high-grade iron-ore deposits at Zouérat (Bonte, 2001). In the Algerian Desert, several Arab groups sedentarized around Ghardaïa and Ouargla for labor opportunities in natural gas and oil exploitation (PROHUZA, 1960). The Kel Ahaggar, though out of the range of oil and natural gas operations, were still exposed to outside interference as Algeria's impendence movement, la Front Libération Nationale, gave a concession to the departing French by allowing their scientists to conduct nuclear detonations at In Ekker from 1961-1966. These detonations had serious

\footnotetext{
${ }^{4}$ Upper Volta is today Burkina Faso.

${ }^{5}$ St. Louis is the former capital of Mauritania and Fort Lamy, now known as Ndjamena, is the capital of Chad.
} 
long-term health effects on the inhabitants of southern Algeria, a claim that the French Defense Ministry has acknowledged but the International Atomic Energy Agency still denies (IAEA, 2005; République Française, 2007).

Customary pastoral groups, their respective governments and neighboring states contributed to the outbreaks of violence in the Sahara and northern Sahel from the 1960s to 1990. Northern Mali was the first to experience a pastoralist uprising. The Socialist Keita Regime looked to dismantle the chieftainship system the French created. Bamako suppressed the revolt by 1964 but it was still essential to work in partnership with the northern pastoral chiefs (Bonte and Claudot-Hawad, 2000; Lecocq, 2004). In Chad, though the civil war was more complex than just a rift between pastoralists and central authority, divisions among the Toubou and rivalries with Arab groups exacerbated an already fragmenting state (Baroin, 1981; United Nations, 1986). Libya's irredentist claims and occupation of the Aouzou Strip, however, temporarily united Toubou and Arabs to push the Libyans out in the 1980s (Burr and Collins, 1999; Buijtenhuijs, 2001). Mauritania's partnership with Morocco in occupying the Western Sahara in the mid 1970s came at a heavy cost. The Polisario attacked the iron ore railway in order to cripple Mauritania's chief revenue maker. By 1978 Nouakchott withdrew (Mundy, 1999; Bonte, 2001). Niger saw no large scale conflicts after 1960 but Nigérien farmers colonizing land to the North of them and uranium exploitation in Arlit sowed the seeds of future grievances when a newer generation of Kel Tamasheq leaders emerged (Ngaido, 1993; Lecocq, 2004). Organized dissention would reappear at a greater scale in the Sahel by the 1990s and later in the 2000s as Niamey parceled out pastoral territory to mining corporations (Sahara Focus, 2009).

The Sahelian droughts of 1968-1974 and 1983-1985 were uneven in their ecological impact but those living in the North, where infrastructure is poor to non-existent, were the most vulnerable (Nnoli, 1989; Prothero, 1994). Central governments were not responsible for the climatic change but their late and ineffective responses when food crises soon followed undermined an already fragile situation regarding pastoral-state relations. For the 1968-1974 drought, the delays taken by Bamako, Ouagadougou and Niamey in admitting to crop failures and escalating grain prices did not help (Cross, 1990; Azarya, 1996). During both droughts when international aid did come its distribution was riddled at times with corruption and mismanagement. Even when authorities acted properly and efficiently, aid distribution to the North arrived too late and retarded local grain production (Neefjes, 2000; Author Interviews, January $2007 \mathrm{~b}$ and d). Since grain prices were very high and returns on animal sales were pittances, pastoralists lost flocks while failies fragmented and migrated in search of opportunities. Arab and Kel Tamasheq faced discrimination in the South; Toubou experienced the same in the Mediterranean (Nnoli, 1989; Krings, 1995). Young men frustrated with what little coping strategies existed for them and their families sought out radical movements in Libya (state-supported for a limited time) and Algeria (Islamic fundamentalists). Called the teshumara movement in the Tamasheq language, some of these men fought in the conflicts in Lebanon and Afghanistan during the 1980s. Their training and experience made them a key element in the Malian and Nigérien rebel factions of the 1990s (Lecocq and Schrijver, 2007).

Much like the violence during World War I, the Malian and Nigérien rebellions of the 1990s were not a united Arab, Kel Tamasheq and Toubou front against central authority. Initially some abstained from the conflict. Recognizing this, Bamako and Niamey sought cooperation from local chiefs to isolate the rebels (Boilley, 1999; Grégoire, 2000; Bonte and Claudot-Hawad, 2000). Grievances against the state, however, were too numerous. 
Recruitment came from more than just the lighter-skinned, nomads in the North. Those joining the rebels included the former slaves and artisans of Arab, Tamasheq, and Toubou backgrounds and in rare cases individuals from farming communities along the Niger River (Grémont, 2005). As the conflicts continued so did the difficulty in distinguishing rebel from non-participant. The prolonged violence divided allegiances between the state and rebel factions. When asked about the rebellions, ex-pastoralists residing in towns showed gratitude for the security they received from the military (Author Interviews, January 2007a). Pastoralists in the countryside, however, continued to criticize their government and empathized with the insurgents' cause (Author Interviews, February 2007b).

Decentralization, which represented a capitulation in the Malian and Nigérien peace processes and trend in regional development throughout the Sahel, became a new path in pastoral-state relations. In Mali and Niger, decentralization called for the transfer of selected administrative and financial powers to local communities and the better representation of Arab, Kel Tamasheq and Toubou in the police and military (Pedersen, 1995; Seely, 2001). Though well intentioned, few powers were handed down and those that were inflamed internal struggles at the local level (Vedeld, 1996; Hesse and Thébaud, 2006; Gutelius, 2007). Rebel leaders were integrated into the police and armies but the nature of these institutions in serving national, not local, concerns and the common practice of placing former rebels at southern posts fail to address the problems of banditry and mistrust of security forces in the North (Author Interviews, December 2007a and February 2008; Ilkjaer and Boureima, 2010). In Mauritania, the repatriation of refugees impacted by the events of 1989 is largely coordinated by the central government instead of the refugees themselves (MacEwen, 2010). NGOs encourage decentralization through the appropriation of funds to local communities for the construction of schools, wells, clinics, etc. but some interviewees have called this practice la nouvelle escroquerie, which translates as 'the new con-game.' Local communities formed quickly and some say artificially, to attract funding from NGOs and national projects (Author Interviews, May 2007). So while decentralization brought peace and promise to the region, it is unexpectedly fragmenting pastoral society further through the recreation of chiefs and community growth that is incompatible with customary pastoral communities.

While decentralization contributes to the reconfiguration of central authority, GWOT is the latest tactic in justifying state coercion of customary pastoral groups in the remote parts of the Sahara and northern Sahel. Since the attacks on the United States on September 2001 and bombings in the United Kingdom, France and Spain, the United States and Europe Union allocate funds, training, material, and intelligence to Maghreb and Sahelian states to suppress extremism and regulate borders in the region (Antil, 2006; Thurston, 2010). The end product is a collaboration between the military branches of Western powers, bilateral and multilateral aid agencies with governments in the region. National governments, however, have taken this one step further by connecting Islamic extremism to their political rivals (Jourde, 2007; Mundy, 2007; Guichaoua, 2009). Morocco, the power that remained in the Western Sahara after Mauritania pulled out, labels the Polisario as drug traders and in the partnership with al-Qaeda Islamic Maghreb (San Martín, 2004; Mundy, 2007). Mali, an active solicitor of GWOT assistance, moved quickly to end an uprising of Kel Tamasheq near the Algerian Border. Ibrahim Bahanga led an uprising in early 2008 to which the Malian government increased 'counterterrorism operations' (African Research Bulletin, 2008; Keenan, 2009). This was also the site of the Mauritanian-French operation to free Michel Germaneau, an aid worker who was abducted in April 2010 (Barchfield, 22 September 2010; Sayare, 26 July 2010). 
Niger was just as inflexible with its northern communities calling the MNJ bandits and terrorists. For two years Niamey took a hard line against the MNJ (Sehmer and Welsh, 26 July 2008; Thurston, 2010), including blame for the Robert Fowler abduction (J. Smith, 13 January 2009; Graham IV, 2010), and only agreed to peace talks after two years of fighting exhausted both sides. Since most MNJ, Ibrahim Bahanga's men and Polisario come from pastoral families and were trained in the military service of Maghreb and Sahelian countries, it is difficult to envisage a close allegiance to extremists. If relations exist between insurgents, terrorist groups and local pastoral communities, it is more likely a forced collaboration since Western powers have given their allies in the Sahara and Sahel the means to lockdown space, further increasing conficts between pastoralsists and with ousiders.

\section{Rationale of Resilience}

Before European colonialism, Arab, Kel Tamasheq, and Toubou groups had extended their political, economic and physical space sometimes overlapping with each other and neighboring sedentary groups in West Africa. In doing so their activities were not solely based on animal husbandry but those complimentary to their expansion such as raiding, protection of vassals, and trade (Ould Cheikh, 1991; Conte, 1991; Retaillé, 1993). Exogenous factors, however, were already deflating this expansion such as the Atlantic sea trade cutting into the demand for TransSaharan crossings for centuries (Lovejoy, 1978; Porter, 1995). As Europeans expanded from the coasts of Algeria, Senegal, and Nigeria into the interior, their suzerainty over sedentary African communities at times constricted pastoral space and other times brought new opportunities. For instance, new markets emerged along the borders of Francophone colonies with the Spanish Sahara, the Gold Coast and Nigeria during the colonial era (Raynaud, 1948; Salvy et al, 1951). ${ }^{6}$ Colonial authorities attempted to regulate it but were once again constricted by lack of resources. Pastoral territory gradually became a lucrative zone for smuggling and clandestine trade.

Before the establishment of colonies, pastoral response to Europeans varied from resistance to evasion and, for some, collaboration. Pastoral groups in rare cases welcomed foreigners, in some cases attacked or took them hostage but in many cases monitored them from a distance (Hourst, 1898; Asher, 2008). Incidents increased as Europeans began formalizing claims to territory but such incidents were isolated, not a collective response (Arnaud and Cortier, 1908; De Salins, 15 Juin 1912). Even the World War I revolts, perhaps the largest movements against colonial intrusion, were contained to pockets of colonial territory (Claudot-Hawad, 1990; Triaud, 1993 and 1996). Among the Kel Tamasheq, Fihroun and some Oulliminden, Kaosen and a number of Kel Aïr were certainly dissatisfied with the changes set in motion by the French but they were a minority of the larger confederations of Kel Tamasheq. The Sanusiyya present in Libya, Niger and Chad carried the universal message of anti-colonialism but only attracted a small number of pastoral bands into their ranks (Spittler, 1993; Triaud, 1996). In special cases rival pastoral groups assisted Europeans against insurgencies. The Chaâmba have already been mentioned regarding their importance in defeating the resistance in northern Niger while a long-standing Arab rival of the Oulliminden, the Kounta, aided the French in eastern Mali (Hrany, 1917; Dimapult, 10 Février 1923; Richer, 1924). Many pastoralists evaded the fighting as customary norms of governance allowed them to abstain. Despite which side pastoralists took during the uprisings, however, their collective space diminished further. The violence during the

\footnotetext{
${ }^{6}$ The Spanish Sahara is now the territory of the Western Sahara and the Gold Coast is now Ghana.
} 
revolts and banditry that followed World War I reduced trans-Saharan routes as caravaniers guarded their shrinking orbits from competition (Clauzel, 1960; Spittler, 1993). ${ }^{7}$ The extension of agriculture and growth of colonial posts into provincial towns brought larger numbers of non-pastoral peoples into the Sahara and drier parts of the Sahel (Teuasson, 8 Mars 1930; Eboué, Mai 1935). Incidents were common, sometimes rekindling old rivalries and other times creating new ones. Among the new rivalries, the Kounta and the Bérabich squabbled over caravan routes and market exchanges in northern Mali, the Reguibat competed with Arab tribes to the South of them for control over the markets emerging in the Spanish Sahara, and the Tamasheq fractions, Kel Gossi and Irraguenaten, fought over pasture and water sources in the Gourma Region of Mali (Martin, 21 Septembre 1926; Teuasson, 10 Février 1927 and 8 Mars 1929).

Despite these contests, the next fifty years were a time of pastoral expansion in the region. Droughts occurred, notably in 1927-1928, 1931-1932 and 1940-1941 but the affects were limited to particular areas and shortlived (De Chaffudeline, 1931; Calvel, 3 Juillet 1942; Nicholas, 1950). Pastoralism, although not the only activity expanding in this period, gave Arab, Kel Tamasheq and Toubou a greater distance from colonial life and the ability to maintain their language, family cohesion, and customs. And while local chiefs were imposed on the Arab and Kel Tamasheq confederations and the anarchistic Toubou, their physical mobility allowed them to distance themselves from colonial life more often than not. In Francophone territory, former servants and ex-slaves looking to take advantage of the colonial presence entered into work projects but were paid too little to subsist on (Dimapault, 10 Février 1923; Alibert et al, 25 Octobre 1943). A few migrated to Anglophone colonies for better wages but others re-established their relationships with former masters. Noble families used this to their advantage, sending the children to colonial schools or young men to fulfill corvée labor (Teuasson, 29 Février 1924; Calvel, 3 Juillet 1942; Hama, 1967). ${ }^{8}$ Other activities complimentary to pastoralism, like trade and smuggling, flourished. International borders and administrative boundaries were difficult to survey by the already understaffed gendarmes and customs officials who reported on the increasing clandestine trade of cloth for livestock with Anglophone countries (Raynaud, 1948; Salvy et al, 1951). Competition with other Africans and limited opportunities already deterred pastoralists from resettling in the more humid and populous south. Yet for them a greater motivation to remain in camp was the foreign culture that existed at Algiers, Bamako, Ouagadougou, Niamey, and Ndjamena. Pastoralism, already a pillar of their culture, ballooned into a foundation.

At the end of the colonial period, brief but lucrative work projects came to the desert involving manual labor, interpreters, and guides earning some pastoral families better incomes. This was particularly true when construction began for mining operations in Algeria, Mauritania and Niger (PROHUZA, 1960; Spittler, 1993; Bonte, 2001). In addition, young adult men migrated temporarily to Ndjamena, Niamey, Bamako, Abidjan, and other metropoles to profit from non-pastoral activities. As to formal education, pastoral schools were few and severely underfunded in pastoral territories, though experimentation with mobile classrooms began in the 1950s (Author Interviews, January 2007c and February 2008). When the French departed, however, the disparities and rivalries between an alien, urban elite to the South and a customary nomadic community in the North were set. Only

\footnotetext{
${ }^{7}$ Caravaniers is a French term used for pastoralists who use their animals to transport commercial goods.

${ }^{8}$ Corvée labor was the conscripted work force for colonial projects during French rule.
} 
the children of ex-slaves who excelled at their studies spoke the language of the independence movements. Their representation in these political parties was minimal, however, and by no means influential or representative of northern communities (Le Rouvreur, 1962; Hama, 1967). Arab, Kel Tamasheq and Toubou became more dependent on pastoralism, and the activities complimentary to such a livelihood.

For pastoralists the droughts meant the destruction or liquidation of their flocks. A Chérifan herder from eastern Mali, though admitting to the extremity of the following incident, recalled losing twenty animals in one day during the hot-dry season of 1973 (Author Interviews, January 2007c). It also meant for many a separation from their families whether temporary or permanent. Young men in the family departed for the larger cities to the South and North. 64 out of 79 males within the age range of 35-55 in the Gao Region acknowledged leaving their parents' encampments for school, wage labor, or menial tasks in urban centers like Bamako, Niamey, Kano, In Salah, and Abidjan during the droughts (Author Interviews, December 2006 - May 2007). Finally, although well-intentioned, the droughts also brought a new set of foreign agents into pastoral territory. NGOs became more prominent in pastoral society during this period. Heads of households remained in the countryside to preserve the remainder of their families' animals, but spouses, elderly and small children migrated to peri-urban areas to seek out work or assistance from these aid organizations. Displaced pastoral women interviewed in Gao and Ménaka were appreciative for the NGO food aid coming from World Vision, Red Cross and Oxfam but were not content with the agricultural materials, microcredit and other forms of aid that soon followed (Author Interviews, January 2007d, February 2007a and April 2007b). For them such assistance undermined their former livelihoods and chances to reunite with their families. Some families reunited and managed to return to pasture; others in Mali and Niger remained vulnerable and susceptible to the impending rebellions.

The 1990s rebellions were for a few Arab, Kel Tamasheq and Toubou an opportunity or means to express their grievances. As mentioned above, some young men filled the ranks of resistance fighters in Lebanon, Afghanistan or trained under the auspices of the Jamahiriya state. ${ }^{9}$ With experience from Algeria to Afghanistan, this generation influenced political actions taken in the 1990s rebellions (Boilley, 1999; Lecocq, 2004; Lecocq and Schrijver, 2007). For most pastoralists, however, the violence was a nuisance and in extreme cases a catastrophe. Many evaded both soldiers and rebels with the consequences of having limited access to pasture, water points, and markets. As can be expected, rogue elements in Arab, Kel Tamasheq and Toubou society profited from the chaos through banditry and theft (Author Interviews, December 2007b and May 2009). Others, though, developed an even greater reliance on their animals' milk and the exploitation of wild foods (Berge et al, 2006; Author Interviews, February 2007b and March 2007b). Those caught in the crossfire or simply met up with combatants experienced harassment, destruction of property, the conscription of animals, or the loss of their lives (Randall, 2005; Author Interviews, February 2007a and April 2007b). Though impoverished they migrated to urban environments or joined a particular rebel group in the countryside with plans to reconstitute their herds after the conflict.

Pastoralists viewed NGO assistance unreliable and too political both during and after the revolts. To their credit NGOs retooled their programs by promoting flock regeneration and redistribution, vaccination of animals, and working in partnership with bilateral and multilateral aid to construct schools, animal parks and cement wells in

\footnotetext{
${ }^{9}$ Jamahiriya state refers to Libya.
} 
remote areas of West Africa (Painter et al, 1994; Bolwig et al, 2009). Though a great departure from the 1970s and 1980 s projects, these endeavors were not without controversy. Some viewed these aid projects as costly, encouraging herders to reduce their mobility patterns, and generating conflicts over natural resource management (Turner, 1999; Neefjes, 2000; Thébaud, 2002). During the violent periods, however, employee security became a major concern, at least in Mali, Niger and Chad, and provided a justification for NGOs to leave (Author Interviews, December 2007b and May 2009; Solé-Arqués, 2009). Yet there was a greater difficulty unfolding before 1990. NGOs after the 1980s famine started 'Africanizing' their staff. This placed Africans in upper and middle management positions, in theory giving them greater control over development and setting a positive role. From what was revealed during the interview process, however, rivalries have formed between individuals from sedentary groups coming from the South and nomadic peoples underrepresented in NGO staff. Despite NGO efforts to improve the living conditions in the Sahara and Sahel most pastoralists view NGOs as just foreign agents much like the central government (Author Interviews, February 2007a and December 2007a). The consequence once again equates to a few participating in NGO programs while the majority abstains.

Pastoral groups' response to the latest foreign intervention, GWOT and terrorists, is problematic not just to the security of the region but also the integration of pastoralists into their respective states. The presence of terrorists and Western military advisors in partnership with African militaries has agitated Arab, Kel Tamasheq and Toubou groups who are accustom to a certain degree of socioeconomic autonomy in the Sahara and its fringes. Once again, most pastoralists evade both sides but there are individual cases where pastoralists collaborate with authorities or, possibly, terrorists. In 2003, Toubou groups in the Tibesti Region turned over to Chadian authorities a mixed group of kidnappers and their abducted hostages for a fee (Sahara Focus, 2009). On the contrary, the continued presence of national militaries in the Sahara and its fringes calls into question whether GWOT is eliminating terrorism or if the funds, military equipment and information is used by Maghreb and Sahelian nations to suppress their political rivals (Antil, 2006; Berschinski, 2007; Guichuaoua, 2009). Participating in a global jihad does not appeal to many Arab, Kel Tamasheq and Toubou, but the agents preaching this rhetoric also offer assistance to communities that have undergone chronic poverty for decades (Ousman, 2004; Gutelius, 2007). The increase in violence and lockdown of space is in all likelihood influencing individuals and groups in pastoral society to either join the ranks of terrorists or abduct foreigners for quick earnings.

\section{Conclusion: Foreign Intervention uniting a Diverse People}

The crisis narrative, though important in understanding the immediate tragedies unfolding in the dry-lands of West Africa, only reveals a fraction of the actions undermining pastoral development in their respective territories. To focus only on the droughts, famines, or revolts omits the everyday actions colonial agents, post-colonials, aid workers, and recently military advisors have taken in Arab, Kel Tamasheq, and Toubou territory. Whether intentional or not, the imposition of a central government and programs wears down, breaks apart, and reconfigures pastoral society. Since colonial times all systems brought into the Sahara and Sahel have proven contradictory to the internal logic of pastoralists. From the onset West African coastal trade, the protection of Sahelian villages from raiding and pillaging, and the emancipation of slaves were just the beginnings of gradual transformations. Later the 
appointment of chiefs, the colonial posts manned by non-pastoral groups, taxes on camels and cattle and monetary economy became encroachments on an already shrinking environmental and economic commons. Post-colonial regimes exacerbated the problem through the expansion of agriculture, mining concessions expropriated in pastoral territory, and greater enforcement of customs and administrative boundaries.

Though pauperized, Arab, Kel Tamasheq, and Toubou evaded colonial and early post-colonial control through herding and complimentary activities. Opportunities arising from the artificial creation of modern states included in the short-term temporary work and in the long-term various forms of commerce from state-licensed to clandestine. Still, pastoral communities had entered a period of risk by relying principally on their animals. Aware of this, some families sent young men off to school and work opportunities outside of their territories. This number grew with the droughts and famines of the 1970s and 1980s but as states closed their borders and urban populations discriminated against them, alienation became collective resistance. Pastoral norms of leadership and governance resurfaced in the peace process as groups fragmented and settled with Bamako, Niamey, and Ndjamena or continued fighting. Decentralization had the intentions of greater autonomy to the pastoral zones throughout the Sahel but in practice imposed newer chiefs and political organization. The Global War on Terror and terrorists are, however, a greater menace in pastoral integration with the state. As long as central governments use outside assistance for their own political gains and pastoralism, commerce and tourism diminish from the lockdown of space, it is likely the Sahara and less-inhabited parts of the Sahel are headed for darker times in state-pastoral relations.

Leaders and aid workers need to reassess top-down approaches in administration and development. Recognition of this is the first step in recognizing the failure of appointing or democratically electing regional or local chiefs for a set of years. Such a practice creates not harmony but instead factionalism and alienation. Permanence and incumbency do not exist in pastoralists' pursuit of natural resources. Thus, why should it exist in their choice of leaders or livelihoods? No condition is permanent for them so their leadership and development projects need the same flexibility as their mobility patterns. To provide pastoralists with flexibility, maneuverability, and space to move, whether physical or metaphorical, is to empower them. Until these groups receive adequate physical space for the maintenance of their herds; political space to manage their own internal affairs, and economic space to stave off risk and reconstitute their herds, any effort at development will be regarded as alien and resisted by subtle, and in extreme cases, violent means. These actions are likely to be perceived once again as illogical and irrational, but given the long term picture of state oppression it is compatible with their internal logic. 


\section{Chapter 3: We Eat with Different Spoons These Days The Maintenance of Pastoralism as a Social Formation in the Sahara and Sahel}

Tidarmène, a commune in Mali's eastern region, is different from many other West African localities with characteristics that alternate between those of the Sahara and Sahel. Most of the time it resembles the desert with rock escarpments, dunes and scattered Acacias (ehrenbergiana, seyal and stenocarpa) lining depressions. When the rains arrive, however, the environs of Tidarmène take on the brief appearance of savannah as grasses such as Andropogon laniger germinate providing fodder to herders' flocks. Before the 1968-1974 drought Tidarmène was a seasonal camp used for pasture by the Ishidenaren, a Kel Tamasheq fraction (Ibrahim, 2006). If the annual rains are good the Ishidenaren are North in the Tamesna to exploit pasture and natron. ${ }^{10}$ As water grows scarce and the heat arrives, they move to Tidarmène. If the rains are bad or absent, they travel as far south as Tillabéry, Niger to find reliable water sources for their flocks (Bernus, 1981; Ibrahim, 2006; SNV-Mali, 2006). Despite the variability of these migration patterns, Tidarmène is an important locality to Ishidenaren pastoralists.

It is March of 2007 and the hot, dry season has come to Tidarmène. At the larger wells camels and donkeys constitute the draft power while at smaller wells men and adolescent boys pull at ropes to bring water for camels, cattle, donkeys, sheep, and goats that huddle together at makeshift troughs. Alahmed ag Alhaceni, also called Tangouza by friends and family, is part of this work force. He takes a break and returns to his wife's tent to enter a discussion with visitors. He is saturated with sweat but drinks no water, instead waiting for the tea his youngest boy prepares for him and his guests. His wife brings him a small bowl of porridge made with wild grains, goat's milk and sweetened with the fruit of Ziziphus mauritania trees, also known as jujubes. The spoon he uses is called tishokalt, made from the wood of acacias and decorated with geometrical designs carved by the women (Hincker, 2005). Before the questions begin, Tangouza explains, "I have a cousin in Marseille, France. He eats his meals with a plastic spoon. My father lives in Abidjan, Cote d'Ivoire. He married a Mandé woman and uses his hand to eat with. My young brother lives in Bamako and buys meals from women who prepare dishes and serves them with metal spoons. But we eat with tishokalt." He is asked which is better, "Tishokalt! The other ways are foreign and contaminate your food but this (Tangouza displays the spoon) is imajeghan.",1

Tangouza elaborates more on the Kel Tamasheq Diaspora and family members living in European and African cities, "They will come back or become the people they live with now." A question is asked: How they will subsist if they return, “... through herding," Tangouza replies. "My brother and cousin are earning money to marry and stock their herds. They will return someday." When discussing the difference between his life and theirs, Tangouza sharply replies, "They are quick to tell me about the money and conveniences they have, but then they complain about high costs and how poor the food is. They say the neighbors steal; the streets are dirty, and that they are discriminated against. It is a trap. They want to leave. But to do so they have to eat less and work harder. Here everyone works hard but there is no pollution, little crime and as long as the rains are good everyone eats. We know risk. We have lived with it for centuries. It is servitude we hate and do our best to escape."

\footnotetext{
${ }^{10}$ Natron is a mineral: hydrated sodium carbonate $\left(\mathrm{Na}_{2} \mathrm{CO}_{3} \cdot 10 \mathrm{H}_{2} \mathrm{O}\right)$.

${ }^{11}$ Imajeghan or 'free man' is a term used by the Kel Tamasheq to signify nobility or a sense of pride in their culture.
} 
Five kilometers away from Tangouza's family camp is the settlement of Tidarmène. It is a typical West African locale. Many such permanent settlements were constructed at the end of the last major drought in 19831985. Government and non-government organizations (NGOs) built granaries and brought assistance to herders losing their flocks. A few herder families settled and opened a handful of shops, work for NGO projects, or manage the dispensary or school. Most, however, restocked their herds and returned to the countryside. Over three-fourths of the homes in Tidarmène are unoccupied most of the year. Farming is practiced by a few but only when the rains are abundant. Planting is limited to millet, sorghum, peas, and melons (Author Interviews, February 2007b). Though weakly established, this settlement represents the first exposure to a cash economy (three general stores), wage labor (teachers, NGO workers, a pharmacist), and sedentarization (permanent residency). At its fringes live families and groups who rely on mobility, and exchanges of labor, foods, and animals for their subsistence. These are the nomadic herders that outsiders believed disappeared (Gritzner, 1988; Krings, 1995; Cour, 2001) or are disappearing (Agnew and Chappell, 1999; Bryceson et al, 2000; Chatty and Colchester, 2002).

Clearly, pastoralists have not disappeared. They are, however, harder to locate and easier to dismiss as vanishing when large numbers lose their herds to drought, famine, disease, market recessions, banditry, and civil unrest. Such disasters affected many from the 1970s through the 1990s with large numbers of pastoralists disbanding to urban areas like Niamey's Tourakou - Lazaret neighborhood (Author Interviews, February 2007a). Once a former refugee camp for Malian and Nigérien Tamasheq during the droughts, it has become a permanent quarter and host to a large animal market (Turner and Williams, 2002). Some have found opportunities in smaller provincial towns like Ménaka, located $200 \mathrm{~km}$ north of Niamey and $120 \mathrm{~km}$ south of Tidarmène. During the 1983-1985 drought and 1990s rebellion World Vision operated in Ménaka and continued their operations until 2003. Their projects were more than food aid and child survival programs. Construction workers, drivers, and translators were also needed (Author Interviews, May 2009). As pastoralists moved to different locations, their livelihoods became more diverse. Tidarmène, however, did not fill with significant numbers of pastoralists. It remains a frontier between a handful of Ishidenaren who lack the means or will to pursue their customary livelihoods and many who still do.

The following chapter analyses the changes taking place in pastoral society and the actions and identity of those who have settled permanently, those who fluctuate between pastoralism and other livelihoods, and those who maintain herds throughout the year en brousse. ${ }^{12}$ Using David Harvey's analysis of Marx's footnote in Capital, Volume I (2008), an argument is made where it appears that pastoral groups like Arab, Kel Tamasheq, Toubou, and Fulani are shifting from time to time back and forth through their customary livelihoods (in Marxian terms: 'precapitalist mode of production') to the foreign capitalist economies they find in more urban environments. Here the focus is on the pastoralists who have not disappeared, those who have, and how trends like global climate change and global market recessions can act as a catalyst for pastoral re-emergence.

\section{Near Future Trends Promoting Pastoral Production}

The misinterpretation of pastoralists disappearing comes from short term studies focusing on catastrophic biophysical and anthropogenic events (Le Houérou, 1977; Timberlake, 1985; Agnew, 1995; De Bruijn and Van

\footnotetext{
${ }^{12}$ French for 'in the countryside,' many interviewees used this to signify mobility and distance from urban areas.
} 
Dijk, 2003), and from regional studies observing the outward migration from rural to urban zones in developing nations (Bryceson, 1996; Bolwig and Paarup-Laursen, 1999; Fanchette, 1999; Raynaut, 2001). Some case studies show a great reduction in pastoral mobility due to the building of permanent wells and other social services (Claudot-Hawad, 1993; Turner and Hiernaux, 2008). Others show less reliance of pastoralism as a livelihood and part of a greater portfolio of income generating activities (Cross, 1990; Blench, 2001; Scoones and Wolmer, 2002). All stress the destruction of many herders' animals during drought through desiccation or market crashes (Starr, 1987; Ould Cheikh, 1990; Turner and Williams, 2002). Such forces thrust pastoralists into sedentarizing, change their livelihood for wage-labor opportunities, or diversification into other income activities. It is understandable why policy makers write off the customary mobile pastoralist. They equate such fluctuations as the end to pre-capitalist modes of production rather than change in social formations. By equating pastoralism to a mode of production, argument over societal transition may sound more convincing but is, in fact, misplaced.

Many customary mobile pastoralists who lost their flocks through climatic events or political unrest of recent decades did not abandon their customary norms when migrating to urban environments. Instead, they brought these behaviors and practices to the refugee camps, the villages, the peripheries of towns and cities. Here the displaced-dispossessed took assistance, engaged in wage-labor, and used money to procure basic needs in the marketplace. At the same time reciprocity, hospitality, and exchanges of labor and food resurfaced between displaced-dispossessed pastoralists and also with non-pastoral peoples. The quarter of Essakan II in Ménaka is a prime example. Starting in the late 1970s, this peripheral neighborhood grew when numbers of Kel Tamasheq from the Dahuasahaq fraction established homes and agricultural plots (see Figure 03). The subsequent drought of 19831985 witnessed the arrival of more Dahuasahaq and also families from the agricultural Songhai. Exchanges of grains, animals, and labor are commonly 'informal' and verbal, not monetary, taxed, or written (Author Interviews, January 2007d and January 2008).

It is true that the customary societies of Arab, Kel Tamasheq, Toubou, and Fulani are no longer completely dependent on nomadic pastoralism for their livelihoods. It is, however, a valuable component providing food and income, and in turn produces specific relations with nature and cultural identity (Nicolaisen, 1963; Burnham, 1996; A.B. Smith, 2005). Still, herd destruction or liquidation does not ipso facto transform these groups from customary to capitalist modes of production. Once 'pastoralists' are correctly conceptualized as a fluid social formation, discussion of their disappearance can be more accurately investigated and located within broader economic processes. For instance, anthropologists have shown how pre-capitalist societies can co-exist with a capitalist economic system (Kahn and Llobera, 1981; Bourgeot, 1982; Burnham, 1996). Clarifying the differences between change in social formation versus change in mode of production gives us a better sense of not only the current status of pastoralists but also how development interventions will affect them.

As a social formation, then, pastoralists negotiate between customary and capitalist modes of production. Before addressing pastoral maneuverability and constraint between customary and capitalist societies however, several endogenous and exogenous factors need addressing. Population growth, particularly for the Sahel, continues to be important in planning at household, local, national, and regional scales (Raynaut, 2001; Bolwig et al, 2009). Larger populations create new opportunities in urban environments but also greater demands for cereals, produce, 
Figure 03: Photo of former pastoral Dahuasahaq family who now cultivate (the children are called future pastoralists by their parents)

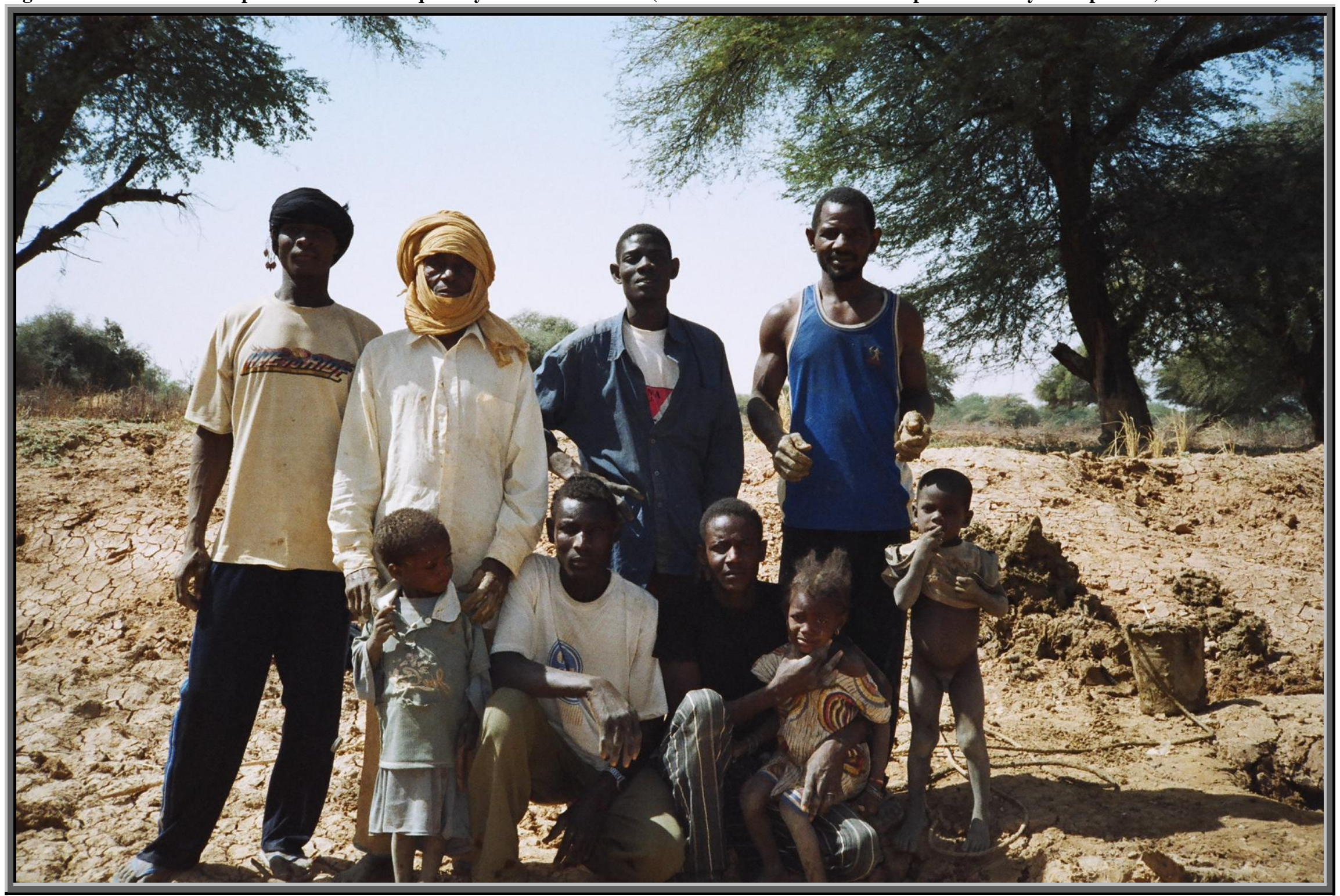

Source: Taken by author in January 2008 at Essakan II quarter of Ménaka, Mali. 
meats, and dairy. Urban residents that once practiced farming, fishing and herding as a livelihood will be needed and are likely to return since they possess the knowledge in these sectors of food production. Furthermore, since pastoralists from Arab, Kel Tamasheq, Toubou, and Fulani groups are relative latecomers to cities like Abidjan, Bamako and Tamanrasset their social and economic marginalization encourages a return to herding.

Social and economic difficulties in urban environments will also push people back to rangelands. Already mentioned is interviewee Tangouza's catalog of crime, pollution and discrimination that his relatives experience (Author Interviews, February 2007b). Other concerns residents voiced at Gao and Ménaka were accidents, taxes, living expenses, and noise. Hospitals, schools, electricity, and running water are services many appreciated but concern regarding high costs for these services were also articulated (Author Interviews, February 2007a and April 2007b). Difficulties exist in the countryside but the mercurial nature of capital economies, unemployment and poor work opportunities experienced during recessions further discourages displaced pastoralists from settling permanently. As difficult and risky as nomadic herding is, it offers maneuverability in seeking out better markets, revisiting customary forms of exchange, and reliance on natural resource exploitation like hunting and gathering wild foods until exchanges rebound (Bourgeot, 1982; Berge et al, 2006).

Trends in global climate patterns create changes in land use that favor nomadic herding. This may sound contrary considering the vulnerability pastoral groups had to famine during the 1970s and 1980s droughts (Du Bois, 1974; Timberlake, 1985; Cross, 1990). However, many studies have shown that pastoral vulnerability comes through social change and political actions taken during the crisis, not the climatic event (Watts, 1987; Behnke et al, 1993). Pasture has been greatly reduced by the imposition of a central authority in colonial and post-colonial eras. The state reduced the commons through the privatization of land, the expansion of agriculture, parceling land to mining corporations and national reserves, and closing boundaries during periods of instability (Poitou, 1982; Bassett, 1988; Ngaido, 1993; Rabeil et al, 2007; Bolwig et al, 2009). Despite these social constraints, pastoralists act when climatic events are favorable. Ménaka and its surroundings increased in pastoral activity after September 2007 due to better rains and mild temperatures. Herders tending to ruminants reported better birth rates though complained that cooler temperatures stunted milk production among ewes and nannies (Author Interviews, January 2008). ${ }^{13}$ Realistically no condition is ideal for all types of animal husbandry. But if climatic variability continues as it has for the past fifty years, populations will need greater mobility to profit from natural resources. In terms of food production, nomadic herding is more adaptable to these changes compared to farmers who till the land.

The state, and to a lesser extent NGOs, will continue to play critical roles in promoting pastoral production. Historically the state has been both deliberate and unintentional in undermining and transforming pastoral society. Interference though not welcome by herders was generally tolerated until droughts and market recessions devastated flocks in the 1970s and 1980s (Seely, 2001; Lecocq, 2004). The civil unrest during Chad's twenty-five year civil war and the Malian and Nigerien Rebellions in the 1990s marked a low point in relations between nomadic communities and central authorities (Krings, 1995; Grégoire, 2000; Buijtenhuijs, 2001). To quell grievances between pastoralists and national governments, pastoral codes and the policy of decentralization was adopted. Both are difficult to implement because of conflict with other laws and national agencies and the incompatibility of top-

\footnotetext{
${ }^{13}$ Ewes are female lactating sheep and nannies are female lactating goats.
} 
down approaches in pastoral society (Vedeld, 1996; Hesse and Thébaud, 2006; Davies, 2008). The appointment or election of leaders to communities for a fixed tenure, a practice that is foreign and untested by many pastoaral groups who are genberally seek leadership during times of arbitration, is another shortcoming. Such a practice divides loyalties and creates competion. NGOs during the droughts and immediately after implemented programs that sedentarized the dispossessed. Changes began in the 1990s as new agendas shifted towards livelihood restoration through restocking animals. This was also controversial, however, as implementation is often costly, outreach limited to a handful of participants, and the distribution of animals at times interferes with customary norms of distribution and exchanges (Neefjes, 2000; Author Interviews, April 2007b).

\section{Pastoral Resilience and Transformations}

Using David Harvey's interpretation of Marx's theoretical perspective regarding the societal transformation from pre-capitalist to capitalist modes of production (2008), examples are drawn from this and previous research that reveals the adaptive approach pastoralists utilize to maintain their livelihoods, improve their circumstances, or abandon animal husbandry altogether. Pastoral society was never static or independent in the colonial and postcolonial eras. It has undergone periods of expansion and retreat, and through these fluctuations experienced change through endogenous and exogenous forces.

Relation to nature arguments are shifting from blaming pastoralists for degrading natural resources to recognition that their practices are sustainable (Bovin, 2000; Davies, 2008; Naseef et al, 2009). Pastoralists engage principally in communal forms of natural resource management under the auspices of an arbiter (Dupire, 1962; Nicolaisen, 1963; Baroin, 1981). Through this and their mobility patterns they reduce risk and exploit what variations there are in spatial and temporal distributions of pasture, water, and natron. Though pastoral commons were reduced through anthropogenic actions in the past hundred years (De Verdière, 1995; Berge, 2001; Grémont, 2005), communal forms of land use remain the norm in rural environments. The communities of Gao, Ménaka, and Tacharan (a Songhai village 25 kilometres from Gao), however, are environments where sedentarised groups practice variances of private and communal resource management. Animals owned in these settlements are generally pooled together during the daytime and tended to by hired herders five to ten kilometers away, an observation that Turner and Hiernaux made regarding changes in Sahelian labor dynamics (2008). Some tend to their own animals, purchasing animal feed and salt in the market or procuring these through bartering goods or labor. While this is common for most of the year, many resume mobility and managing their animals by departing one to three months out of the year when the rains come. This is also a practice of individuals coming from non-pastoral backgrounds, like Songhai, Hausa, slave and artisan Kel Tamasheq castes who have managed to invest in small ruminants and in exceptional cases cattle and camels (Author Interviews, January 2007b and April 2007a).

Fuel wood collection and charcoal production are activities often assigned blame for the degradation of natural resources (Benjaminsen, 1997; Bolwig et al, 2009). Many pastoralists who lost or liquidated their flocks during the famines or civil unrest turned to these to subsist. 59 out of 72 displaced-dispossessed pastoralists interviewed in Gao, and, 20 out of 43 interviewed in Ménaka indicated a reliance on wood collection and charcoal fabrication for income, particularly the elderly and women (Author Interviews, December 2006 - May 2007). 
Interviewees at other localities collected wood for household consumption or to exchange with their neighbors. They collect wood during the day with one or two donkeys to transport fallen limbs and trimmings from live trees (Author Interviews, February 2007b, March 2007b and February 2008). When interviewing a Kel Tamasheq group eight kilometers east of Gao, this researcher and his interpreter were not allowed to interview until wood was collected for making tea and warmth during the night (Author Interviews, January 2007c). As a collective, this practice, is seen as an obstacle to sustainable resource management as it is feared that demand will encourage people to excessively prune or remove trees (Fanchette, 1999; McPeak, 2001). Critiques like these often omit the larger exploitative practices of Lorries circulating the countryside to fell whole trees and collect larger quantities of wood in less time for urban markets (Author Interviews, March 2007b).

Questions about technology distribution and utilization are crucial in understanding the degree of transformation. In many cases there is a duality between those who maintain customary inventions and innovations and those who obtain them from outside. Customary wood-framed wells are dug alongside cement wells (Thébaud, 2002). People and animal draft power draw water at the same encampments. At Emnaghuil, Mali, camels, cattle and a Mercedes Diesel 190 sedan took turns pulling water to the surface (Author Interviews, April 2007a). Some shepherd their flocks thousands of kilometers and across two or more international boundaries to exchange their animals. Others are visited by merchants or former pastoralists who purchase animals and transport them to larger markets by motorcycle, pick-up truck or lorry (Turner and Williams, 2002; Gagnol, 2006; Author Interviews, December 2006). The extent to which a technology transforms pastoralists depends on both diffusion and employment of the technology.

Cell phones while touted as a prolific change in pastoral society are limited to urban and periurban centers where cell phone towers and service exist. Tidarmène did not have service at the time of the interviews (February 2007). Those who possess cell phones are often people dependent on non-pastoral activities and constantly visiting urban areas for their work as schoolteachers, NGO workers, artisans, and merchants. This was the situation observed in Gao and Ménaka (Author Interviews, December 2006 - May 2007). Development agents associate cell phones with the opening of new information portals for pastoralists in their search for pasture and favorable markets (Naseef et al, 2009; De Jode, 2010). The optimism does not reveal the depth of cell phone use in pastoral society or whether it is used in pastoral information exchange or for other non-pastoral activities.

The internet has had a more profound on transforming pastoral societies. Though internet literacy and use is less frequent than cell phone use, it is key in attracting tourism to the Sahara and Sahel, marketing artisanal jewelry and leather, promoting Kel Tamasheq music, aiding local NGOs, and vital in raising awareness and promoting indigenous peoples' rights. The MNJ during 2007-2009 conducted an energetic campaign on the internet, expressing frustrations over corruption in Mohammedou Tandia's rule and multinational corporations buying mining concessions in the Aïr Region without the consent of local communities, further fragmenting the pastoral commons (Benjaminsen, 2008; Guichaoua, 2009; Graham IV, 2010). The teshumara, although not representative of all Kel Tamasheq and certainly not illustrative of all pastoral peoples, brought their egalitarian ideals and disdain for the caste system through the medium of the internet. This may prove revolutionary for Kel Tamasheq society and broadly influence other pastoral groups who use the internet in promoting their causes (Lecocq, 2004). 
Relations of production were profoundly transformed through external shocks and internal stresses from past to present. Animal and labor exchange, kinships, caste systems, name giving, stocking, and forms of reciprocity are part of a non profit system and are often done to reduce risk and create alliances (Kahn and Llobera, 1981; A.B. Smith, 2005). Some of these have changed over time and through outside interference. European colonialism undermined or transformed parts of pastoral society through suppressing raiding, emancipating slaves, and installing chiefs for tax collection. Many pastoralists, however, maintained physical and social distance from the colonial state. Slavery ended, but in some places reemerged depending on circumstances. The chieftainship system imposed on decentralized groups like the Kel Tamasheq and Toubou endured through colonial and post-colonial times, though the compliance and collection of taxes and revenue was sporadic. Weak administrative practices and favorable climatic events in the 1950s and 1960s opened opportunities to ex-slave castes and individuals to move into pastoralism. Among those interviewed in Gao and Ménaka were middle-aged members of Songhai and Hausa who owned herds before the 1980s. Their social connections to Kel Tamasheq families made access possible but as drought, famine and civil unrest became widespread, the death of their animals and new entry into pastoral society undermined their ability to remain pastoralists (Author Interviews, January 2007b and April 2007b). The loss brought them back to their villages or more commonly to urban centers where other opportunities were greater.

Those who maintained their herds pursued one of two changes in their mobility patterns. A majority reduced their orbits seeking a greater reliance on local natural resources at their encampments. This is the case for many distant from urban areas (Author Interviews, February 2007b and March 2007b). Some however, particularly those possessing dromedaries, changed or increased their orbits to partake in greater opportunities beyond their customary routes. Arab groups are heavily involved in legal trade, clandestine, and variations of both in the northern Sahara and Mauritania (Arditi, 2003; Adepoju, 2006; Pliez, 2006). Malian, Burkinabe and Nigérien Fulani have strengthened their presence in Côte d'Ivoire, Ghana, and Nigeria as favorable markets and cattle crossbreeding have allowed greater access than before (Blench, 2001; Basset and Turner, 2007). Kel Tamasheq groups engaging in small-scale caravan trade cross the central Sahara and Sahel sell tobacco as far North as In Salah, Algeria and trade dates, salt, and animals as far South as the Nigerian towns of Kano, Sokoto, and Maiduguri (Author Interviews, February 2007a and May 2007). Toubou in the eastern parts of the Sahara and Sahel have changed their patterns, partially because of climatic variability but also because of socioeconomic opportunities that are compatible with their migratory patterns (Retaillé, 1998; Clanet, 1999).

Like relations of production, social reproduction also experienced some change and transformation. As mentioned before the internet and emergence of a teshumara elite challenge the continuance of caste systems among Tamasheq groups. Caste roles though are far from historical relics. The importance of name and social roles used in social reproduction endures in many circles particularly those coming from the Karansar, a Tamasheq fraction found in the Kidal Region of Mali. Through their migratory habits they were located and interviewed in Gao during 2006. The Karansar are a religious caste believed to be the direct descendents of the prophet. On a daily basis they receive alms, sometimes as small as a few West African CFA francs and other times as generous as ruminants or large animals. ${ }^{14}$ Karansars who were interviewed revealed that their societal status allows them to restock their animals

\footnotetext{
${ }^{14}$ West African CFA francs are the currency of eight African countries and trades roughly at 1 USD $=480$ CFA.
} 
relatively quickly after the droughts (Author Interviews, December 2006). In times of abundance when people are able to give more the Karansar use their gifts to assist people in the community and in some cases gain political influence over chiefs or other influential leaders.

Pastoralists who lost their animals and settled in urban environments are examples where social reproduction broke down considerably. As part of a Diaspora and detached from their customary societies, pastoral families moved into non-pastoral activities. Men in the household became day laborers in construction and transportation while women and elderly practiced farming and fuel wood collection. Most families who own small goat or sheep flocks desired returning to pasture but because of their age, means, and misfortune recognize they will not. Their children are a different matter, however. Many have learned animal husbandry from their parents and grandparents and possess the skills to return. During this research some young interviewees whose families relocated to Gao and Ménaka during famines and violence now shepherd flocks further away. Others stay in town continuing their studies or participating in commercial or business opportunities. These individuals expressed no interest in following their heritage and fit into transitory roles from customary to capitalist society. A young Ishidenaren man who constructed Ménaka's only hotel voiced his desire to bring the 'noise of Bamako' to eastern Mali (Author Interviews, March 2007a).

Social relations are important on all scales whether local, national, or international. Locally sedentary groups are key to food security in pastoral society as millet, sorghum, corn, wheat, and rice are the staples of Sahelian and Saharan pastoralists (Dupire, 1962; Nicolaisen, 1963; Bonte, 1967; Bernus, 1988). In the Ménaka Region pastoralists exchange their animals for millet with Hausa communities; in the Gao Region for rice at Songhai villages along the river. The collection of wild foods and food exchanges between neighbors and groups are also decisive in food procurement (Berge et al, 2006). From those interviewed, foraging wild foods is more common a practice en brousse though many ex-pastoralists in towns occasionally give and receive food from neighbors and friends. According to all those interviewed acts of reciprocity wane during dry seasons and periods of dearth and are more uncommon at any season in the larger cities (Author Interviews, January 2007d and April 2007b).

Nationally, pastoral relations with their governments are generally better in North Africa and more problematic in West Africa. There are exceptions to this as the Tamasheq in Burkina Faso are fairly well tolerated and the Toubou in Libya are greatly discriminated against (Keita, 1998; Zuelch, 2010). Overall problems arise from demographic, representative, and territorial inequalities. Pastoral groups are typically minorities in their respective states and often overlooked regarding national programs and participation. Their isolation during colonial times created educational and political divisions that Maghreb and Sudanese African political elites profited from. But while pastoralists are a minority and under-represented, they are stewards to large swaths of territory in North and West Africa. These challenges at times thwart peaceful relations between pastoral groups and national governments as evidenced in the Chadian Civil War as well as the Malian and Nigérien Rebellions (Buijtenhuijs, 2001; Seely, 2001). Mauritania appears an exception to poor pastoral-state relations in West Africa because of the government's family connections with pastoral groups in the central and northern regions. At closer inspection, however, Nouakchott has difficulties with integrating pastoralists at its peripheries in the extreme north and south. Polisario leaders (some coming from the Arabic speaking Reguibat) are suspicious of Mauritania's stance regarding the 
Western Sahara, abstaining from an endorsement of Western Saharan independence (Mundy, 2007). In southern Mauritania, the events of 1989 that generated much violence, though not state-supported, forced many Fulani herders to abandon their pastures and well and cross the river to Senegal (MacEwen, 2010).

Internationally pastoral groups have nurtured alliances with French activists, the international NGO community, and received greater exposure from the United Nations through its millennium goals. Tamasheq and Fulani groups are the primary recipients of this publicity, using the coverage to promote the maintenance of their livelihoods, resource base, and culture (Lecocq, 2004; GITPA, 2007). Lagging behind in such coverage are Arab and Toubou groups, however. Both are poorly integrated into Niger, both are fighting for a national role in the economy and politics of Chad, and in Libya the Toubou and dissidents to Qaddafi's government are discriminated against and or suppressed. Little is reported on what these two groups face regarding present and future challenges.

Culture is significantly different between Arab, Tuareg, Toubou, and Fulani groups (Dupire, 1962; Nicolaisen, 1963; Baroin, 1981). Yet differences grow even greater when comparing them as a collective with the inhabitants of coastal North Africa and the more humid parts of the Sahel. Mediterranean and Sudanese peoples, though unsatisfied with their respective governments, through their numbers have more political clout and input compared to pastoral groups. ${ }^{15}$ Tamasheq and Fulani members frequently assembled together at Arab-owned stores in the marketplaces of Gao and Ménaka during 2006-2008. When approached and asked about their choice they had explained that Arab merchants are 'friends from the wells' and sources of information for market prices and current events (Author Interviews, February 2007a and May 2007). Pastoralists were observed mixing with non-pastoral peoples in the village of Tacharan but the atmosphere was tense (Author Interviews, January 2007b). One interviewee frustrated with his visit commented, "We are not welcome here. The rice growers [Songhai] have nothing to talk to us about. When we are in the countryside we learn more about Gao, Tombouctou, and Bamako than we do here next to the river. These people just want a few of our animals; we want their rice. We will leave after an exchange is made."

Cultural change is perhaps most expected among the sedentary ex-pastoralists living on the fringes of urban environments. There is no refuting the need for displaced-dispossessed pastoralists to learn local vernaculars and work in income activities they view as inferior and incompatible with pastoralism (Bourgeot, 1989; Krings, 1995; Bovin, 2000). Among those interviewed in Gao and Ménaka, a handful of Kel Tamasheq admitted to changing their norms by marrying two or more wives, speaking on Songhai at home, or engaging in 'Western' behaviors like drinking alcohol (Author Interviews, February 2007a and April 2007b). It is critical to note though that most interviewees at the same sites abhorred such practices and were quick to exclude anyone who committed such acts as not Kel Tamasheq. For them these negative aspects of their new environments have reinforced differentiation between pastoralist vs. non-pastoralist, Kel Tamasheq vs. not Kel Tamasheq, and imajaghen vs. infidel.

\section{Assessment: Have pastoralists registered changes in all six moments?}

For change in mode of production to occur, change in all six of these moments must register as real. In this section an assessment is made of examples from above to show that while pastoralism as a social formation indeed waxes

\footnotetext{
${ }^{15}$ Sudanese refers to Black Africans of the Sahel here, not citizens of The Sudan.
} 
and wanes, there is sufficient evidence to suggest that for many pastoralists change is not registered in all six moments and thus there are still large swaths of customary production in Sahelian West Africa, whether lying dormant and confined in urban areas or active in the countryside.

Based on the scope of this research and analyses in other studies, overall few have made the transformation in Harvey's 'six moments' and fully integrated into a capitalist economy. That said complexity exists between differentiating those who change, those who for various reasons alternate between their customary society and capitalist economy, and those resisting profound capital influences in their own society. Interpretation (which this article is guilty of) is static but people are not and whether pastoralists of north-eastern Mali and other parts of the Sahel and Sahara match the conclusion in this chapter or not depends on both their own agency and the external factors that shape and influence their socioeconomic environment. It is predicted that population growth, global climate change, and urban social problems will push many ex-pastoralists or their children back into nomadic herding. It is recognized that an abrupt reversal of any or all these trends or other factors may certainly hinder, retard, or accelerate such a prediction. An analysis of each moment and its status among pastoralists interviewed in north-eastern Mali is now examined.

\section{Moment One: Relation to Nature}

Limited transformation has taken place in pastoralists relation to nature. The Diaspora during the famines and rebellions fractured pastoral groups between those who principally tend flocks and those who sedentarized and diversified livelihoods to various degrees but their relation to nature altered little. Those maintaining sizable flocks and residing in rural areas continue to be dependent on exploiting water, pasture, natron, and they are reliant on the longevity of these resources. Not standing isolated from other moments, pastoral groups' relation to nature is certainly influenced by technologies like motor pumps and changes in migratory patterns. The complaint consistently registered in the Malian communities of Emnaghuil and Djébok was a depletion of water levels at the wells (Author Interviews, April 2007a and February 2008). These two locations have undergone water table reductions because of increasing Kel Tamasheq and Fulani settlement and from greater access to the groundwater through the use of motor pumps and construction of cement wells by NGOs, bilateral and multinational aid.

Significant changes in pastoral relations were expected in the larger towns of Gao and Ménaka since pastoral groups who lost their flocks have less dependence on natural resources. This, however, was far from practice. Service employment and a monetary economy became critical for most but reductions in relations to nature came quantitatively and between household members, not qualitatively. Women, grandparents, and children collect fuel wood, fabricate charcoal, and collect wild foods year round (Author Interviews, February 2007a, April 2007b and May 2007). During the rainy seasons the family parts as a unit for the countryside with their small flocks, taking as little as three weeks or as much as three months in shepherding their animals, harvesting wild grains, and rekindling their experience en brousse (Author Interviews, January 2007a and d). These revisits, whether nostalgic or an act of resilience, are vital in their children's and grandchildren's relations with nature. The pastoral practices taught to them not only recreate relations of nature but also overlap with the moment of social reproduction. 
Figure 04: Possessions of a Pastoral Encampment in Northern Mali (only the tire is left behind when the family breaks camp)

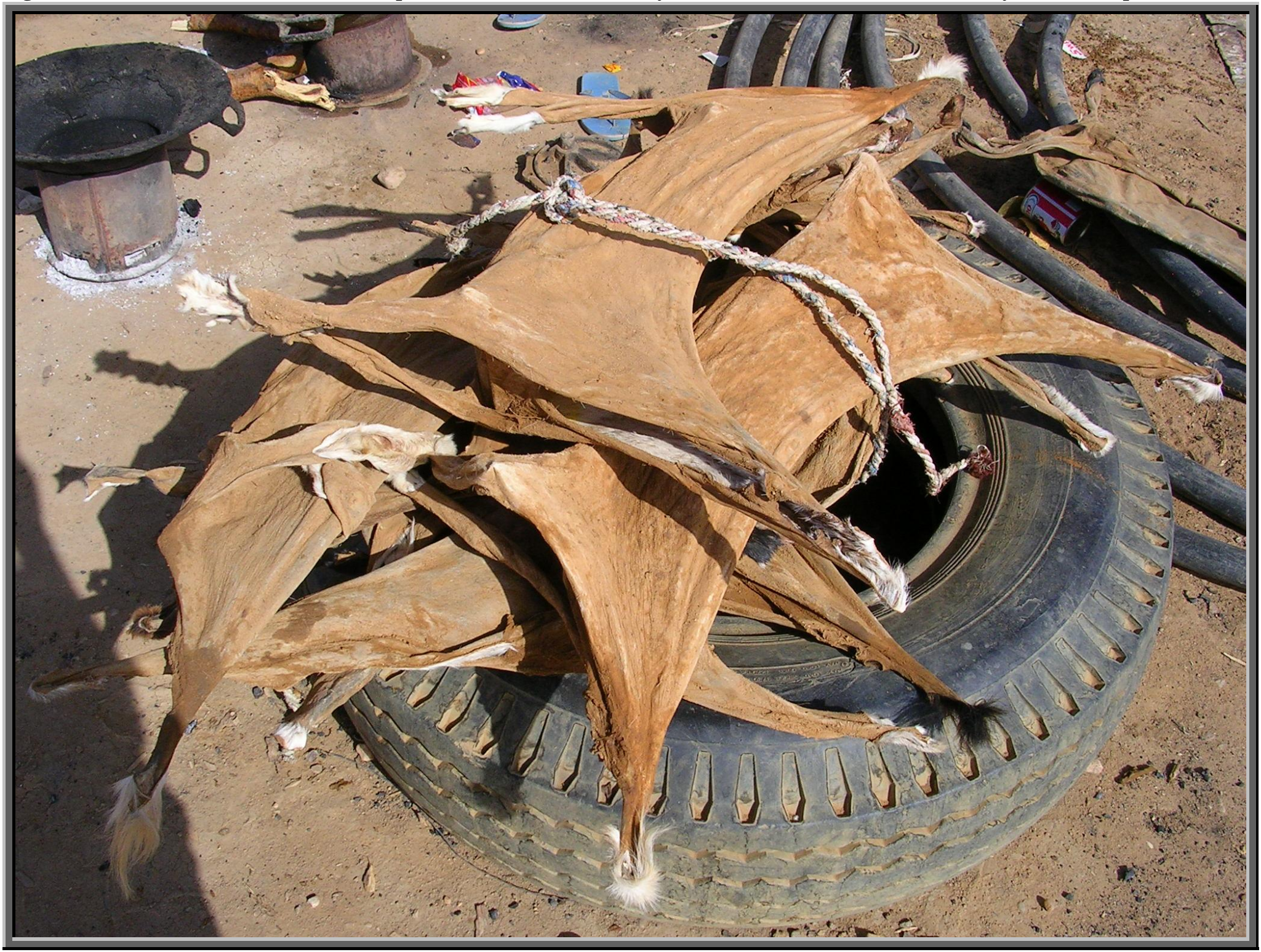

Source: Taken by author in December 2006 at Anéfis, Mali. 


\section{Moment Two: Technology}

Technological transformations occur in both superficial and profound ways. Once again the influence of a technology on transforming a society depends on its adoption and employment. Historically new technologies were often well-guarded or confined to specific castes. Nobility monopolized the production of camel, cattle, and horses; artisans guarded techniques in metal casting (Bernus, 1981; Conte, 1991; A.B. Smith, 2005). With monetary markets and urban services offering new technologies to those who are in proximity of them, a disparity has grown in pastoral society where it is more common to locate ex-pastoralists and those of non-pastoral backgrounds like exslave castes and artisans using cell phones and internet compared to those in remote areas who through technological illiteracy or unreliable service do not benefit from either.

During this research, it was observed that products made of plastics, metals, and rubber were common in pastoral encampments but employed simultaneously with products made with animal skins, plant fibers, and other natural materials (Author Interviews, January 2007c, February 2007b and March 2007b; see Figure 04). Such products have not transformed pastoral society but instead exist in a complimentary function to its modes of production. Motorized vehicles and cement wells have in case-by-case studies produced dramatic changes in modes of production and social relations (Thébaud, 2002; Gagnol, 2006; De Jode, 2010), but cost and maintenance of these innovation limit their diffusion and acceptance. This partially explains the continuance of caravans and traditional well construction. Where change can occur in prolific ways are through newer educational programs and internet use though both are not universally accessible (Boccanfuso et al, 2008; Moreira and Bayraktar, 2008). Interviews with instructors at Emnaghuil, Tidarmène, and Tin Abao revealed curriculums using Tamasheq and Arabic in daily instruction including Tinifagh and Arabic script, a departure from colonial and pre-rebellion days when pastoral children were instructed in French or non-pastoral languages (Hama, 1967; SNV-Mali, 2006). Internet use goes beyond the scope of this research but has significance in bringing new ideas and growth of an ethnic and livelihood consciousness, at least among the teshumara in Tamasheq society if not other social movements in pastoral society.

\section{Moment Three: Relations of Production}

Out of all the moments, greater changes occurred in pastoral relations of production as evidenced by the amount of literature dedicated to relations of production (Ould Cheikh, 1990; Turner, 1999; Bovin, 2000; De Bruijn and Van Dijk, 2003). As mentioned above and by other researchers, pastoral mobility patterns altered considerably during the droughts and civil unrest. What these alterations equate to however have different meaning at individual levels. Many who kept their livelihoods reduced their orbits or changed them in adapting to anthropogenic barriers. Others have actually increased their migrations for herd maintenance, to profit from better markets, and seize on commercial activities (Retaillé, 1998; Walther, 2009).

A larger transformation is evident among the displaced-dispossessed pastoralists who settled at the fringes of Gao and Ménaka during crises. Over time these refugees created the neighborhoods of Sosso Koïra and Essakan II. Fixed in place most of the year, they depend either on purchasing animal feed or having a family member or hired herder shepherding their flocks during the day (Author Interviews, January 2007a and d, April 2007b). All of these strategies involve a cost (money, exchange of goods or labor), which adds to other urban ills like accidents which 
retard herd growth. Since flocks are too small for a permanent return to pasture flocks have become a modest insurance policy for families or in other situations and a financial burden. Displaced-dispossessed pastoralists' employment commitments, expenses, and social ties are other complexities that either constrain or compliment future goals. Their children possess greater maneuverability between the customary and capitalist words of their parents. They may return to pastoralism as a livelihood, engage in particular aspects of it or abandon it altogether.

\section{Moment Four: Relations of Social Reproduction}

By appearance social reproduction also appears greatly transformed but a longer perspective uncovers strategies taken in reproducing pastoralism as a livelihood for current and future generations. Pastoralists like Tangouza have family members who left their camps and work in urban centers to send remittances or save for marriage and the purchase of animals. Individual sacrifice is seen collectively regarding the actions taken by the displaceddispossessed pastoralists from the 1970s, 1980s, and 1990s. While losing their flocks was not their choice, the towns they migrated to, income activities entered, and strategies taken since then are part of their own volition. At Gao and Ménaka, the few pastoralists who admitted defeat in ever returning to their former livelihoods pointed to one or two of their children and adamantly called them the pastoralists in the family. Whether concrete goals or nostalgic pride, given the planning families take in training their children (as revealed in relations of nature and production), the regional demographic and climatic trends for the Sahel and Sahara, their assertions may ring true in the near future. They sacrifice so that newer generations of Arab, Kel Tamasheq, Toubou and Fulani can become pastoralists.

Before committing to the optimistic view of ex-pastoral children returning to former pastures, one dilemma from the research is addressed: the preference younger generations have regarding urban or country life. Admittedly only 27 of the 262 subjects were between the ages of 16-25 and this age group was evenly split between people living in towns and rangelands. All easily commented on the benefits of both lifestyles but to make an accurate assessment of which directions young people gravitate to extend beyond this study's findings. The influences are possible to summarize, however. Higher education, job opportunities, and greater social activities are powerful forces attracting pastoral youth to remain in or migrate to urban environments (Blench, 2001; Pliez, 2006), much like to young Ishidenaren hotel owner in Ménaka. Many subjects, however, young and old, prosperous and destitute, stated nomadic herding as an important part of their cultural heritage and scorn for the socioeconomic ills of urban life (Authors Interviews, December 2006 - May 2007). These polar trends will likely continue their division of those who are pastoralist and those who are not.

\section{Moment Five: Governance}

Changes in governance are limited, problematic, yet more lucid than other moments. The chieftainship system, the leadership recognized from the revolts, and the local leaders who have emerged through the process of decentralization after the revolts are discordant with customary pastoral government. Customary forms are variable between different nomadic groups in the Sahel and Sahara, particularly between a hierarchal Arab society and more decentralized Toubou (Baroin, 1981; Bonte and Claudot-Hawad, 2000). However, in the scope of north-eastern Mali local leaders elected democratically, or appointed through Bamako, or designated quickly for funding purposes 
through decentralisation projects are perceived as foreign agents. Nomadic herders principally rely on the family unit as the principal governing agent. When conflicts arise between two or more families, arbiters are the next recognized authority, sometimes represented by a local chief and other times an individual agreed upon by the parties in dispute (Bonte and Claudot-Hawad, 2000; A.B. Smith, 2005). After this local chiefs and tax collection are tolerated though commonly evaded. Leaders of larger collectives are temporary, not recognized by all encampments, and chosen only for one task or political issue (Claudot-Hawad, 1993; Boilley, 1999). It is this bottom-up approach to governance, a self-governance that conflicts with the centralized state that persists despite efforts to dismantle it for the past 100 years.

Policy makers and academics stress the gravity of amicable pastoral-state relations and its significance in security for the Sahel and Sahara (Painter et al, 1994; Vedeld, 1996; Naseef et al, 2009; De Jode, 2010). To achieve this, however, is more than a herculean feat. Animosities with Bamako were widely expressed among pastoralists in the rural areas during the field research but less so with displaced-dispossessed pastoralists in Gao and Ménaka (Authors Interviews, December 2006 - May 2007). Given school curriculums designed for pastoral renaissance and exposure to the internet, however, the children of urban ex-pastoralists may form a newer generation of teshumara. Their significance in the 1990s rebellions and the influence in the recent 2007-2009 Nigérien Rebellion were nothing short of pivotal. Yet the promises made at peace conferences and pastoral codes written soon after came into conflict with other agencies and laws (Bolwig et al, 2009; Naseef et al, 2009). What is even more difficult, but needs constant toil and reworking until all concerned parties agree, is the development of local pastoral governing systems that conform to customary practices but compliment central authority. What roles NGOs, international indigenous rights groups, and regional organizations have will depend on the national policy these and other Sahelian and Saharan governments take with pastoral groups.

\section{Moment Six: Culture}

A strong argument is made regarding the tenacity of culture practices in resisting exogenous influences. Culture is, of course, not static and caution must be taken when defining what constitutes a pastoralist, yet Africans constantly make such distinctions. Returning to Tangouza's words, those who tend to animals en brousse have a great sense as to who is a 'pastoralist' and who is not. Tangouza identifies his experience as Kel Tamasheq, imajeghan and pastoralist. The lives of his other relatives are not, regardless of their circumstance. Such a ruling is not fixed, however, as circumstances can change. The argument is that many who are displaced and own too few animals to return to their former livelihoods are still pastoralists because they maintain other components of their customary identity that coexist in a capitalist, urban environment. Moments where such symbiosis is maintained are relations with nature, technology, social reproduction, and governance. Even among the most destitute ex-pastoralist households like in Sosso Koïra, Gao dichotomies of capital and customary goods, individuals exploiting local resources and those engaged in salaried employment, cohabitate. These individuals employ both worlds not because of indecision or that they are in transition from customary to capitalist, but because they need both to survive and plan their own and their children's future. 
Pastoralists who maintain their livelihoods, own sizable flocks, move around the countryside, contribute to the labor around wells, perform acts of reciprocity and hospitality, assist those in need, and act as a collective, maintain an identity much different from those in urban environments. Urban dwellers use money exclusively in exchanges, work for others, and in some cases till the land. One interviewee of the environs of Tidarmène (a neighbor of Tangouza) made the point that money does nothing in the pastures; it is toil and solidarity that completes the daily tasks. The separation between these two worlds is not always distinct, however, as interviewees on the fringes of Gao and Ménaka revealed. Toil and solidarity occur in urban environments at times; individualism and alienation divide those in rural settings also (case in point, the competitive atmosphere the pastoralist vocalized in Tacharan, see Pastoral Resilience and Transformations above). The foreignness and monetary economy were and are experiences the pastoral Diaspora have faced moving to urban centers but at the same time they are not the only people who shifted into these societies and economies. At their new homes they befriended other pastoral and non-pastoral people who also have compatible systems of reciprocity, hospitality, and assistance. What role(s) this dichotomy will play in reproducing pastoralism as a livelihood and land use remains open to future investigations.

\section{Conclusion: Those who are Pastoralists and those who are not}

Pastoralists will re-emerge as viable entities when academics and policy makers recognize that they have not disappeared. Physically and symbolically, nomadic herders are beyond the permanent settlement of Tidarmène, Mali and experience profound internal and external pressures, either imposed on them or shaped by them. Arriving at an encampment with a driver, translator, questionnaires, audio recorder, and pen in hand attracts mostly the curious and destitute (as NGO assistance has influenced some individuals behavior) but to say these willing participants are representative of a disappearing pastoral society is problematic. Alahmed ag Alhaceni and interviewees like him at Tidarmène and Bilalkawol were a matter of good fortune. Other occasions during this research were not so fortuitous. It was observed while seeking out subjects in Mali around the environs of Tin Abao and Emanghuil that many herders fled when seeing a kaffir, the Kel Tamasheq word for foreigner (Author Interviews, March 2007b and April 2007a). The majority consenting to interviews at these two localities were settled or semi-sedentarized. Some were representative of displaced-dispossessed pastoralists struggling to restock their herds and return to pasture while others have willingly settled due to age, raise crops, ranching, or to pursue other income activities. They are hardly representative of the herders who fled when seeing a foreigner.

The numbers of displaced-dispossessed pastoralists categorized as part of the 'disappearing' trend are more difficult to assess. A few have fully transformed themselves as wage-earners dependent on markets and social services for theirs and their children's betterment. Among the Arab, Kel Tamasheq and Fulani interviewed, older generations not possessing the strength to herd any longer and those disinterested in practicing their customary forms of behavior have done so (Authors Interviews, December 2006 - May 2007). Others have used opportunities in a capitalist economy to restock their herds and return to pasture for either part of the year or entirely. Those identified as doing so were often younger, industrious, and by their own testimonies 'fortunate.' Most, however, fall between these two situations, favoring to maintain customary ways while either struggling in or profiting from their daily contact with a capitalist economy. 
To those familiar with pastoral issues in the Sahara and Sahel in the last forty years, the following statement may sound absurd: In the near future researchers could be studying the disappearance of wage-laborers and interviewing ex-mechanics, ex-carpenters, and ex-school teachers in nomadic camps. But given the realities of global climate change, socioeconomic realities in African towns and cities, and a burgeoning Sahelian population, this may have some merit. Large numbers of middle-aged ex-pastoralists in Gao and Ménaka have realistically dismissed chances of returning to rangelands. However, they use their kinship ties and urban incomes to prepare their children for such a future. State and NGO actions will certainly influence urban/rural directions. But pastoral groups will resist unpopular programs or adapt them through their movement between customary and capital societies. The customary society of Arab, Tamasheq, Toubou and Fulani peoples will change, perhaps through the greater penetration of capital. To dismiss their customary society as disappearing is premature at best, perhaps even unlikely for the foreseeable future. These groups have been balancing between the two extremes of capitalism and customary pastoral practices for a long time and are likely to sustain this duality. 


\section{Chapter 4: Quantitative Vegetation Changes In north-eastern Mali Using Local Knowledge and Landsat TM Imagery, 1986-2007}

The integration of local knowledge combined with remote sensing imagery offers a means to study vegetation changes in the northern Sahel and southern Sahara. Many do not use using local knowledge, opting instead on the combination of biophysical and remotely sensed data. Conclusions in these studies are commonly mixed. Some show the current limitations of change detection studies by pointing out the shortcomings in using different scales, datasets and localities (Friedl et al, 2000; Petit and Lambin, 2001; Fensholt et al, 2009). Adding to the difficulty are complexities in biophysical relationships, limited meteorological and historical data concerning vegetation change (Agnew, 1990; Milich and Weiss, 2000; Lupo et al, 2001; Heumann et al, 2007). Those focusing on anthropogenic contributions are split between two different conclusions. One group limits their conclusions to land cover conversions (Foody, 2001; Lambin et al, 2003). Another group makes empirical judgments regarding human contribution to vegetation and biodiversity loss. Factors viewed as culprits by this camp include fire control, fuel wood collection, overgrazing, trampling, and the expansion of agriculture (Sharma et al, 1989; Moleele et al, 2001; Thiam, 2003; Javzandulam et al, 2005; Twumasi and Merem, 2007). Not all agree, however in the inevitable loss of biodiversity when local populations modify land cover. James Fairhead and Melissa Leach showed in their analysis of Guinea Forestière Region that people contributed to a quantitative increase in land cover and maintenance in biodiversity from colonial times to the present (1996, 2000).

African languages hold qualitative information that through proper analysis reveal data regarding local resource management (Ag Sidiyene, 1996; Krogh and Paarup-Laursen, 1997). In regards to flora, many languages assign a name to places where specific flora is found in 'useful' amounts or 'unusual' abundance. This is not to say the area is homogenous, the plant consistently the major groundcover, or the area is immune to change. The attachment of flora names to places, however, assists in identifying and categorizing resources for exploitation (Berge et al, 2006). Conflicts exist over access to these resources but over time, local people negotiate and form social norms that aid in the stewardship of natural resources (Bernus, 1981; Ag Sidiyene, 1996). As an example, for pastoralists, the indication of where certain grasses, herbs, shrubs and trees are found is information helping in choices regarding stocking, mobility and social interactions with non-pastoral peoples (Bernus, 1981; Bourgeot, 1999). Camels, cattle, sheep and goats have their own preferences regarding forage, some overlapping, some separate regarding what they graze and browse (Von Maydell, 1983; Arbonnier, 2009). For this study, the Kel Tamasheq language is used to identify places where certain flora are found. The Kel Tamasheq do not always assign flora names to places nor are they the only group doing so. They are, however, with the exception of villages and towns located along the Niger River, the principal stewards of north-eastern Mali. This role makes the Kel Tamasheq language vital in understanding historical and contemporary patterns of vegetation change for the region. Their place names are useful to herd maintenance, food security and the health of both humans and animals.

Some change detection studies are criticized as 'data driven,' in other words implemented for the use of the technology more than a social, economic or ecological benefit (Turner, 2003; MacMillan and Koenig, 2004). Qualitative information revealed during the interviews conducted during fieldwork in north-eastern Mali is used to avoid such pitfalls (Author Interviews, December 2006 - May 2007). 262 pastoralists were interviewed in the 
departments of Gao, Ansongo and Ménaka, two-thirds of them identifying with and speaking the Kel Tamasheq language. Using Landsat Thematic Mapper (TM) data, Intstitut Géographique National (IGN) maps acquired in Mali, and the flora place names of the Kel Tamashq, this study identifies the quantitative changes in vegetation localities, lists possible biophysical and anthropogenic causes for such change, and then collectively analyzes spatial patterns of change in the region. The flora place names are identified on the IGN maps, the IGN maps are georeferenced to the Landsat TM data, and then polygons are drawn to represent the flora place names to select regions of interest for the vegetation change detection study. Comparisons are made for the 2006 cold season-2007 hot-dry season and a long term analysis for the years 1986 and 2006.

Vegetation change detection studies for West Africa commonly use univariate image differencing with outputs that portray change uniformly per pixel (Fontès and Guinko, 1993; Milich and Weiss, 2000; Serneels et al, 2001; Thiam, 2003). NDVIs (Normalized Difference Vegetation Indices) are commonly a component in this algorithm with Landsat TM bands 3 (visible red) and 4 (near infrared) as the inputs (Fensholt et al, 2009), although not all agree on these bands or NDVI as ideal for vegetation change detection studies in dry land environments. Moleele et al has shown that in certain circumstances Landsat TM bands 5 and 7 (mid infrared data) are more accurate in detecting changes with tree and shrub species (2001). Coppin et al, however, has iterated that Landsat TM band 3 holds the highest information content for vegetation cover monitoring (2004). Alternatives to NDVI include the Modified Soil Adjusted Vegetation Index and the Stress Related Vegetation Index. When used in vegetation classification studies for desert and steppe environments, these two alternative vegetation indices had greater accuracy than the NDVI (Javzandulam et al, 2005; Jafari et al, 2007).

Another concern exists over the assignment of 'change' or 'no change' to pixels that are relatively large in area dimension. Landsat TM data, which is $30 \mathrm{~m} \times 30 \mathrm{~m}$ resolution, may not depict subtle changes in vegetation change or even classify vegetation accurately in this 'winner-takes-all' classification method. The vegetation in the Sahara and northern Sahel is sporadic and certainly not uniform with the boundaries of square pixels, thus some academics recommend using what are called 'fuzzy' classification methods to determine these variances of change within the pixel (Foody, 2001). In short, fuzzy classification methods use data within other bands to determine the statistical degree of change occurring within the pixel, generating output maps that reflect these variances (Foody and Boyd, 1999). This study employs 'fuzzy' classification methods by using ENVI's Linear Spectral Unmixing mapping method to generate change maps that are then used in a bi-temporal change detection method for northeastern Mali. The regions of interest, the polygons derived from the Kel Tamasheq place names, are used in the comparisons for the seasonal change in 2006-2007 and the 20 year change for 1986 and 2006. This is an exploratory piece. The intention is solely to determine if spatial patterns are discernable through this method, and to use any information generated from this analysis in future investigations.

\section{Flora Identified in Interviews}

The Kel Tamasheq's willingness to share, list, and map places of customary resources was invaluable. Some interviewees, when products of the plant were available like the grains of Panicum laetum kunth, leaves of Boscia senegalensis, or the fruit from Ziziphus mauritania, retrieved them during the interview to explain their benefits. For this study, thirteen plant species, classified by their ten Kel Tamasheq place names were chosen. Seven of the 
thirteen plant species chosen in this study are trees or tree-like shrubs. These are Acacias: ehrenbergiana, seyal and stenocarpa, classified as one since many Kel Tamasheq do not distinguish between them; Balanites aegyptiaca; Maerua crassifolia, and Ziziphus, lotus and mauritania, as the Kel Tamasheq of lower latitudes do not distinguish between them. Two are shrubs: Boscia senegalensis and Calotropis procera or apple of Sodom. Two are herbs: Abutilon pannosum and Tribulus terrestris. Finally the last two are grasses: Andropogon laniger, also known as camel grass, and Panicum laetum kunth, which produces an edible grain called fonios. These thirteen species were common in interviewees' responses and are distinct in their biophysical properties and practicality to local populations (see Figure 05 for the Kel Tamasheq place names and their geographic coordinates).

For the Kel Tamasheq and other communities in the Sahara and Sahel, the seven tree species are highly valued (Depierre and Gillet, 1991). To pastoralists possessing cattle, goat or sheep flocks, the three Acacia species and Maerua are excellent forage (Calabrò et al, 2007; Desalew, 2008; Diatta et al, 2008). Conservationists use these three Acacia and others in reforestation campaigns throughout the Sahel and, along with Maerua, are a crucial food source for wild fauna (Campbell, 1997; Milewski and Madden, 2006; Noureddine et al, 2010). The Balanites and Ziziphus are relatively more difficult to regenerate than the Acacia and Maerua species but both have important roles in food security for Saharan and Sahelian populations. The leaves of Balanites and Zizphus make excellent fodder, while the edible fruits are consumed in regular years and during periods of famine (Ag Sidiyene, 1996; Berge et al, 2006). Balanites produces a bittersweet fruit called the desert date while both Ziziphus varieties bear small round fruits called jujubes in French (Osuga et al, 2008; Elfeel, 2010; Singh et al, 2010). Balanites can live up to 100 years, the wood when burned is high in caloric energy, and is commonly sought after for construction because of its durability (Gebauer et al, 2002; Montes et al, 2010).

Boscia senegalensis and the apple of Sodom have particular medicinal and veterinary uses for West African populations (Von Maydell, 1983; Antoine-Moussiaux et al, 2007). Between the two, the Boscia has greater value as forage, providing fruits and leaves that are highly desired by goats (Baumer, 1981; Kim et al, 1997). Humans also eat the fruits and prepare sauces using the leaves (Berge et al, 2006). The apple of Sodom is toxic for humans, dromedaries and bovines and only consumed by goats when there is no alternative (Von Maydell, 1983; Pereira $e t$ $a l$, 2010). Both are considered invasive (Barry, 1989; Vincke et al, 2010). The larger stems of apple of Sodom are used to smoke fish in the Lake Chad Region and occasional employed in construction materials and charcoal production (Silva et al, 2010). Pastoralists indicate the colonization of land by the apple of Sodom is often a sign of overgrazing (Kumar and Bhandari, 1993; Ali et al, 2000; Boutraa, 2010).

The relative value of particular species to different interests is evident with the two herbs: Abutilon pannosum and Tribulus terrestris. For pastoralists, both are highly palatable to camel and goat herds (Dorges et al, 2003; Taia, 2009). For farmers, however, the two herbs are nuisances, creating more labor for them. Abutilon and Tribulus are weeds that farmers uproot from their millet and sorghum fields (Noel et al, 2003). Conservationists have a differing view, however. In the fight against desertification, conservationists plant Abutilon and Tribulus to stabilize sand dunes. Both have tremendous adaptabilities to extreme events. Abutilon is resistant to drought (Taia, 2009). Tribulus recovers well from fire (Walton, 2003; Walton and Walsh, 2004). If climate change ushers in more droughts to West Africa, these two species may grow significant in the fight against desert encroachment. 
Figure 05: Table of Vegetation Scientific Names, Kel Tamasheq Names, and Locations

\begin{tabular}{|c|c|c|}
\hline $\begin{array}{c}\text { FLORA: } \\
\text { LATIN NAME }\end{array}$ & $\begin{array}{c}\text { FlORA: } \\
\text { Kel TAMASHEQ NAME }\end{array}$ & $\begin{array}{c}\text { LOCATION OF FLORA: } \\
\text { MAP ... [LATITUDE; LONGITUDE] }\end{array}$ \\
\hline Abutilon pannosum & $\begin{array}{l}\text { Afarak } \\
\text { Aguersman } \\
\text { Esab }\end{array}$ & 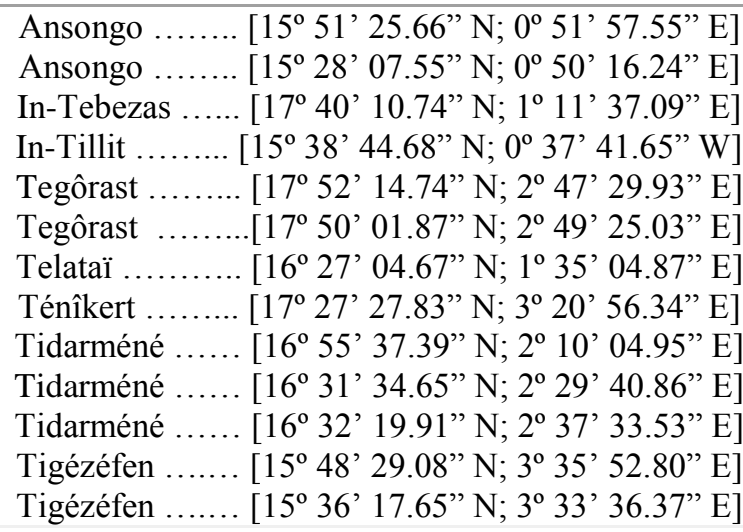 \\
\hline $\begin{array}{l}\text { Acacia ehrenbergiana } \\
\text { Acacia seyal } \\
\text { Acacia stenocarpa }\end{array}$ & $\begin{array}{l}\text { Oraf } \\
\text { Orof } \\
\text { Tamat } \\
\text { Temeut }\end{array}$ & 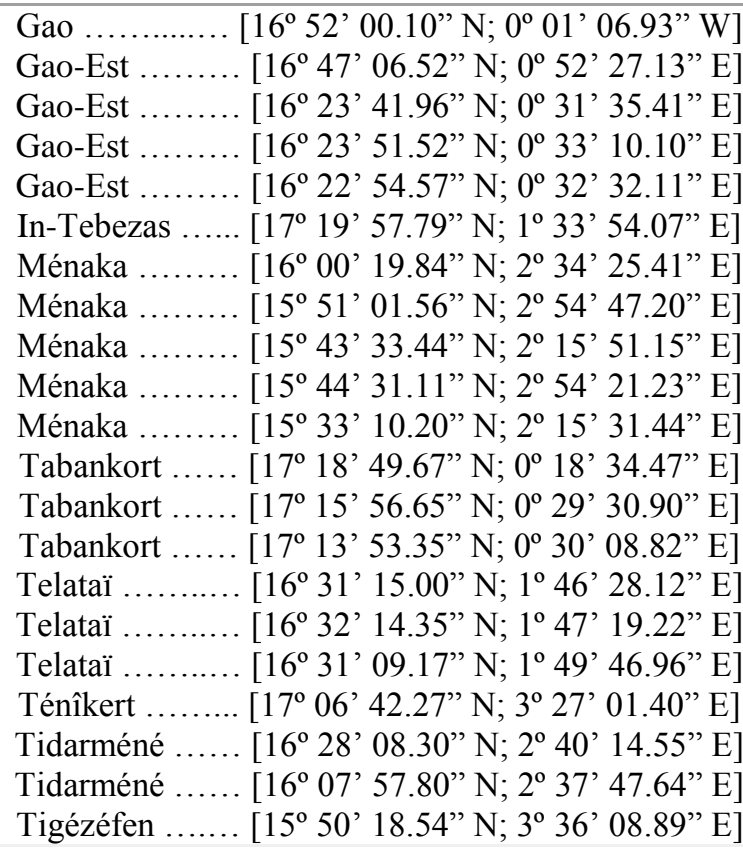 \\
\hline Andropogon laniger & Teberemt & 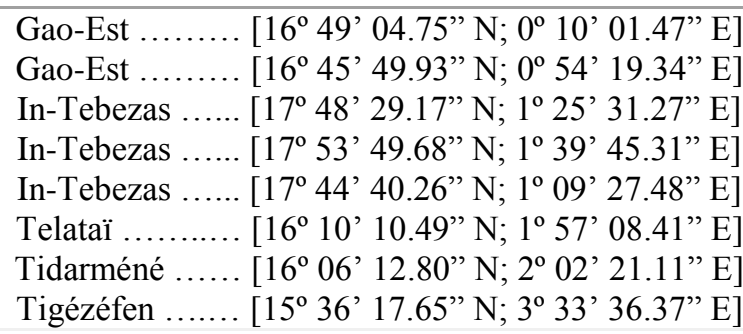 \\
\hline Balanites aegyptiaca & $\begin{array}{l}\text { Taboraq } \\
\text { Tiboraq }\end{array}$ & 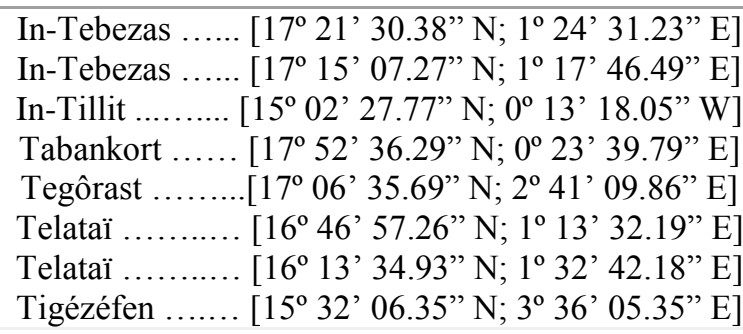 \\
\hline Bosica senegalensis & $\begin{array}{l}\text { Tadan } \\
\text { Tadant } \\
\text { Tadhant } \\
\text { Tadomet }\end{array}$ & 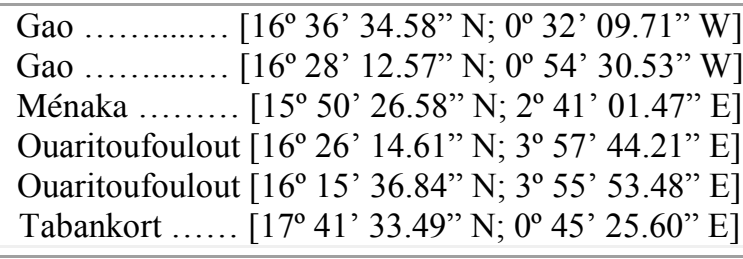 \\
\hline Calotropis procera & $\begin{array}{l}\text { Talza } \\
\text { Tirza } \\
\text { Torcha } \\
\text { Torsa } \\
\text { Toulza }\end{array}$ & 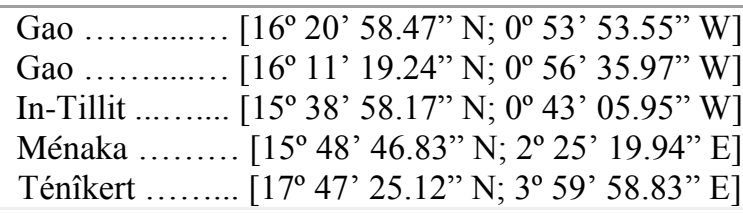 \\
\hline Maerua crassifolia & $\begin{array}{l}\text { Adiar } \\
\text { Agar } \\
\text { Ajarr }\end{array}$ & 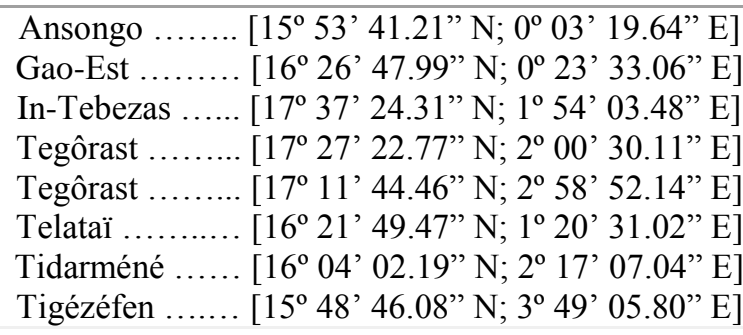 \\
\hline Panicum laetum kunth & $\begin{array}{l}\text { Akasof } \\
\text { Allon } \\
\text { Asghal } \\
\text { Ishiban }\end{array}$ & 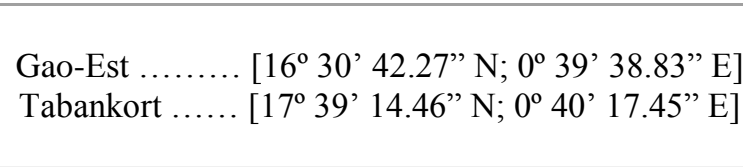 \\
\hline Tribulus terrestris & $\begin{array}{l}\text { Adjorof } \\
\text { Agerof } \\
\text { Aguerof } \\
\text { Tajaroft }\end{array}$ & 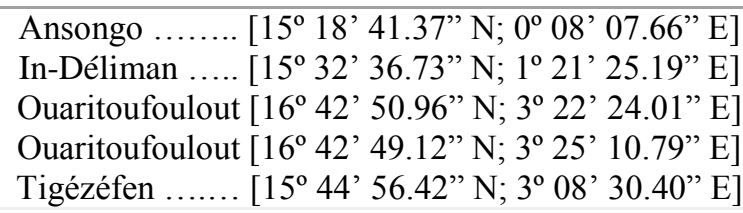 \\
\hline $\begin{array}{l}\text { Ziziphus lotus } \\
\text { Ziziphus mauritania }\end{array}$ & Tabakat & 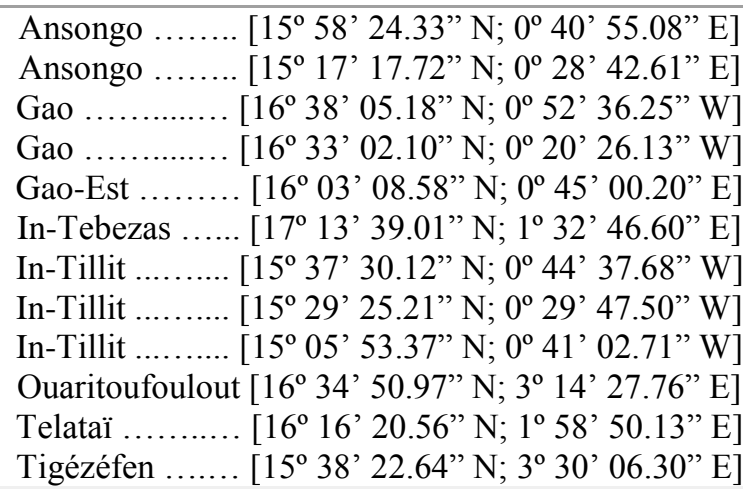 \\
\hline
\end{tabular}


The two grasses have greater benefits to both mobile and sedentary populations compared to the herbs and shrubs. Camel grass and Panicum laetum kunth make excellent forage to both domestic and wild animals (Abaye et $a l$, 2005; Aremu and Onadeko, 2008). Camel grass is used as thatch for rooftops in addition to the making of rugs, mats and bedding (Agonyissa and Sinsin, 1998). Some studies have shown that camel grass rejuvenates soil nutrients in soils common to West Africa (Ouédraogo et al, 2006; Some et al, 2007). The grains of Panicum are harvested by local communities to supplement their grain consumption and the grass is used for animal fodder (Maiga, et al, 1991). In addition pastoralists utilize the grass to rejuvenate pasture that has degraded or desiccated (Aune, 1991; Müller et al, 2004; Yadang et al, 2009).

These thirteen plant species neither exhaust the list of foods, fodder and medicines that local groups extract nor encompass the diversity of the hundreds of plant species in north-eastern Mali. They are, however, potential gauges in understanding vegetation changes for the region. Acacia are replanted to combat deforestation. Panicum is utilized in restoring degraded pasture. The desert date tree is a highly desired construction material and energy, thus is under serious threat if urbanization and fuel wood collection practices are degrading natural resources (Lykke $e t$ $a l$, 1999). Ziziphus is highly adaptable to temperature and salinity; Abutilon and Tribulus are resistant to drought and fire. Changes in these three populations may indicate a changing climate, land use practices, or perhaps other biophysical and anthropogenic causes of change. The apple of Sodom provides a different end of the spectrum as it is less desirable than most plant species. Though it is native to desert environments, its growth and colonization in new areas is a sign for many Africans of land degradation. The various characteristics of these thirteen plant species and their value to local communities make them important to understadning the vegetation dynamics of northeastern Mali and relevant to other vegetation studies in the Sahara and Sahel.

\section{Data Acquisition and Pre-processing}

To link Tamasheq flora names to their corresponding regions in the remote sensing images, ancillary data was needed. During the 1950s the French colonial administration acquired extensive aerial photography over the Sahel and Sahara. The Institut Géographique National, with offices in both Paris and Dakar, were responsible for the final products: IGN maps drawn at 1/200 000 scale. Though these IGN maps were produced in France and Senegal they were only available through Mali's own Institut Géographique du Mali, located in Bamako's neighborhood of Sogoniko at the time of research. For coverage of the departments where interviews were conducted fourteen IGN maps were needed (see Figure 06). IGN maps were purchased at the time of study and used during daytime interviews when time and space permitted. When necessary they were revisited in the evening with the interpreter to verify locations listed during meetings with Kel Tamasheq pastoralists.

Satellite data for north-eastern Mali dates as far back as the 1960s with Corona imagery but differences in resolution, length of missions, and availability of data sets are generally inconsistent with one exception beginning in 1984. NASA's Landsat TM provides images $210 \times 240$ kilometers in size. While these images have neither the largest swaths nor the greatest in detail, they are accessible at no cost at the United States Geological Survey's website: http://www.usgs.gov. A total of twenty-seven images were needed for producing three mosaics (see Figure 07). Dates for north-eastern Mali are based on creating a comparison between the 1986 and 2006 cold season 
Figure 06: Table of IGN Maps of north-eastern Mali used in the Study

\begin{tabular}{|c|c|c|c|}
\hline $\begin{array}{l}\text { Map } \\
\text { Name }\end{array}$ & $\begin{array}{c}\text { Place } \\
\text { Produced }\end{array}$ & $1^{\text {st }}$ Edition Printing & $\begin{array}{l}\text { Year(s) of Aerial } \\
\text { Missions }\end{array}$ \\
\hline Ansongo & Dakar & 1959 & $1950-54$ \\
\hline Gao & Dakar & 1959 & $1954-55$ \\
\hline Gao-Est & Dakar & 1959 & 1954-55 \\
\hline In-Déliman & Dakar & 1961 & $1950,1954-56$ \\
\hline In-Tebezas & Paris & 1960 & $1954-55$ \\
\hline In-Tillit & Dakar & 1958 & $1954-56$ \\
\hline Ménaka & Dakar & 1961 & 1954-56 \\
\hline Ouaritoufoulout & Paris & 1970 & $1954-55$ \\
\hline Tabankort & Paris & 1960 & $1954-55$ \\
\hline Tegôrast & Paris & 1971 & $1954-55$ \\
\hline Telataï & Paris & 1970 & 1954-55 \\
\hline Ténîkert & Paris & 1967 & $1954-55$ \\
\hline Tidarméné & Paris & 1970 & $1954-55$ \\
\hline Tigézéfen & Dakar & 1962 & 1955-56 \\
\hline
\end{tabular}


mosaics and a seasonal comparison between the 2006 cold season and 2007 hot-dry season mosaics to understand long-term and seasonal changes in vegetation reflectance.

Climate is an important determinant of changing vegetation patterns (Nicholson, 2005). For the region, meteorological data is limited to Gao, Bourèm, Ansongo and Ménaka (see Figure 8). These, however, produced continuous records before and during the study period. The mean rainfall averaged over all meteorological stations for the years of 1981-2006 was 255 mm (Dobigeon, 1987; Sivakumar, 1991; CILSS, Septembre 2006). Means for the 1986 and 2006 rainy seasons were below this, with $203 \mathrm{~mm}$ in 1986 and $192 \mathrm{~mm}$ in 2006 (Sivakumar, 1991; CILSS, Septembre 2006). Five year averages before 1986 and 2006 reveal greater heterogeneity. The mean for 1981-1985 is $164 \mathrm{~mm}$ while 2001-2005 is $233 \mathrm{~mm}$ (Dobigeon, 1987; CILSS, Septembre 2006). The large discrepancy comes from the drought years of the 1980s (Agnew and Chappell, 1999; Hulme, 2001). It is expected the differences in rainfall events will influence comparisons of reflectance performance for perennials (trees, shrubs and herbs) and annuals (grasses). Perennials will likely fare better in the 2006 mosaic compared to 1986 due to the drought years in the 1980s. The reverse is predicted for the grass species. Since the seeds of annuals can lie dormant for years, it is expected 1986 offered better conditions than 2006. The frequency of rainy days is also influential in this prediction. The number of rain days averaged 14 days in 1986 and 10 days in 2006 (Sivakumar, 1991; CILSS, Septembre 2006). The seasonal comparison between the cold season of 2006 and 2007 hot-dry season was chosen to check differences observed between 1986 and 2006 and to provide some insight into the seasonal changes of reflectance for each specie's locality.

Phenological conditions are also considered in the individual analysis of flora changes. Variances in vegetation species' growth during different parts of the year are expected as not all flower, fruit, shoot leaves, or drop leaves simultaneously. Even among the Acacias, there are different periods of flowering and fruiting, though the choice of December proved satisfactory for the three Acacias under investigation (Guinko, 1992). Human activities are also crucial to individual analysis. Panicum laetum kunth is exploited by local peoples during the second half of the rainy season, generally August to October (Maiga et al, 1991). The species' localities identified by the Kel Tamasheq are compared to geophysical preferences for these flora. For instance, Balanites and Maerua are commonly found upstream in wadis (temporary river beds) while Acacias tend to be scattered in the channels or downstream (Chenoune, 2005; Shaltout et al, 2010). ${ }^{16}$

\section{Methods}

All IGN maps were scanned at 600 DPI (dots per inch) on a Graphtec CS 600-11 Proversion 1.60 color scanner and geo-referenced to the same projection as Landsat data: WGS-84 Universal Transverse Mercator projection using LEICA Systems ERDAS Imagine software, version 9.3. A second order polynomial fit was estimated with a minimum number of 104 ground control points and maximum of 125 for geo-referencing. Root mean squared error varied between 00.008 to 00.003 . Kel Tamasheq place names that correspond to individual flora were then identified

\footnotetext{
${ }^{16}$ Wadis are a common name for intermittent streams or valley riverbeds in the Sahara and Sahel.
} 


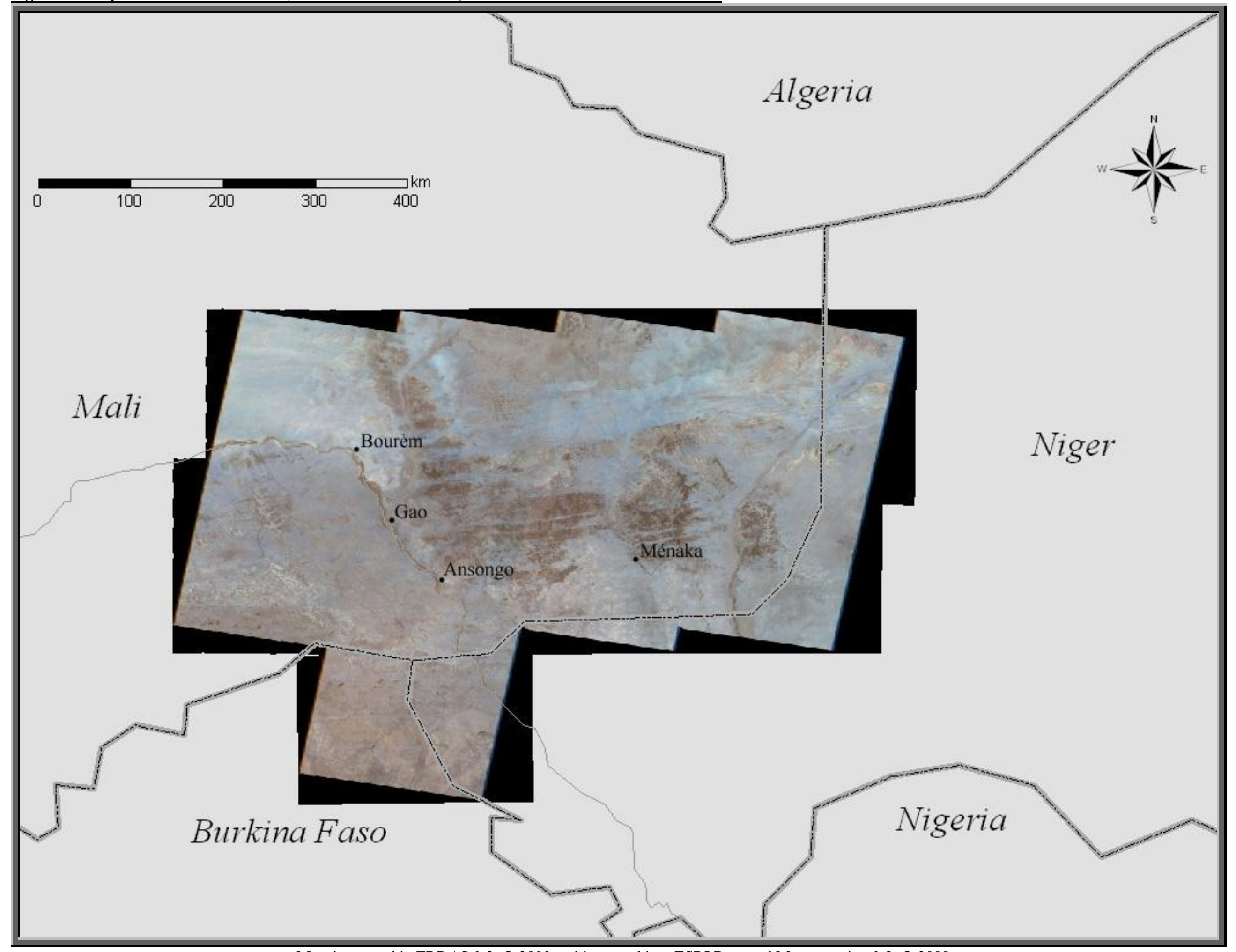

Mosaic created in ERDAS 9.3, (C) 2009 and imported into ESRI Data and Maps, version 9.3, ( 2008. 
Figure 08: Table of rainfall patterns at four meteorological stations in north-eastern Mali

\begin{tabular}{|c|c|c|c|c|c|c|c|}
\hline $\begin{array}{c}\text { Meteorological } \\
\text { Stations }\end{array}$ & $\begin{array}{c}\text { 1986-2006 } \\
\text { Mean Rainfall }\end{array}$ & $\begin{array}{c}\text { 1981-1985 } \\
\text { Mean Rainfall }\end{array}$ & $\begin{array}{c}1986 \text { Mean } \\
\text { Rainfall }\end{array}$ & $\begin{array}{l}\text { \# of Rain } \\
\text { Days } 1986\end{array}$ & $\begin{array}{c}\text { 2001-2005 } \\
\text { Mean Rainfall }\end{array}$ & $\begin{array}{l}2006 \text { Mean } \\
\text { Rainfall }\end{array}$ & $\begin{array}{l}\text { \# of Rain } \\
\text { Days } 2006\end{array}$ \\
\hline Bourèm & $197 \mathrm{~mm}$ & 88 mm & $202 \mathrm{~mm}$ & 17 & $247 \mathrm{~mm}$ & $200 \mathrm{~mm}$ & 12 \\
\hline Gao & $272 \mathrm{~mm}$ & $161 \mathrm{~mm}$ & $236 \mathrm{~mm}$ & 18 & $235 \mathrm{~mm}$ & $188 \mathrm{~mm}$ & 14 \\
\hline Ansongo & $301 \mathrm{~mm}$ & $263 \mathrm{~mm}$ & $287 \mathrm{~mm}$ & 15 & $229 \mathrm{~mm}$ & $263 \mathrm{~mm}$ & 9 \\
\hline Ménaka & $250 \mathrm{~mm}$ & $144 \mathrm{~mm}$ & $87 \mathrm{~mm}$ & 6 & $221 \mathrm{~mm}$ & $117 \mathrm{~mm}$ & 5 \\
\hline Mean & $255 \mathrm{~mm}$ & $164 \mathrm{~mm}$ & $203 \mathrm{~mm}$ & 14 & $233 \mathrm{~mm}$ & $192 \mathrm{~mm}$ & 10 \\
\hline
\end{tabular}

Data Sources: Dobigeon, 1987, Sivakumar, 1991; Centre Régional Agrhymet, 2006; Ibrahim, 2006 
by latitude ; longitude, listed, and used later to digitize polygons representative of Kel Tamasheq flora localities. Columns two and three in Figure 05 show the Kel Tamasheq names and their locations where these polygons were derived from the corresponding maps.

The twenty-seven Landsat TM scenes used to make the three mosaics were all radio-metrically corrected using a dark object subtraction method and the cosT approach (Chavez, 1996; Baugh and Groeneveld, 2006; Chander et al, 2009). This was done to normalize for the varying effects of scattering and aerosols. This approach has been shown to be as accurate as other complex methods (Moran, et al, 1992; Coppin et al, 2004). The mosaics were then reduced by creating a subset file from an area of interest defining the administrative borders of Gao, Ansongo and Ménaka departments. The resulting mosaics are representative of the principal natural resource base exploited by most in north-eastern Mali by others coming from northern Burkina Faso and western Niger.

\section{Analysis}

The IGN maps' geographic representation for Tamasheq flora place names vary. In a few cases there is only a name without indication of the boundaries that define the resource. In some cases green dots or tree symbols are used to define an area. A majority of cases have a corresponding wadi, plain or depression depicted. In rare cases the representation is intentionally drawn as a field (common with maps of lower latitudes where the phenomenon of brousse tigré occurs) ${ }^{17}$ Given the discretion of the cartographer in representing forests, pasture and other vegetation stands, only cases where boundaries are relatively distinct (i.e. swards, riverbeds or valleys) are chosen in the analysis. In regards to ground truth data, most Kel Tamasheq place names were not visited, thus, this study relies on the Kel Tamasheq in distinguishing the flora. The purpose of digitizing the Kel Tamasheq place names was to create exploratory regions of interest in the analysis of vegetation change for north-eastern Mali.

Vector files were digitized using IGM map data reference. $51 \%$ of these object representations were wadi channels, $43 \%$ were flood plains/alluvial fans, and the remaining $6 \%$ were depression pockets in dunes. When comparisons were made between the digitized areas representing Kel Tamasheq place names, it was observed that some physical features like wadis and alluvial fans did not match up with their respective physical features in the Landsat TM data. Reasons for this may involve simplification by the map's cartographer(s), geo-referencing error, sensor distortion, or a combination of any of these. Two steps were taken to correct this. First if the digitized vectors matched phenomena in the image (for example, with the wadis) then the digitized boundaries were moved to the corresponding feature in the Landsat image. If there was ambiguity, as was the case with many flood plain vectors, then the boundaries were eroded by 100 meters to provide a conservative estimate of the area portrayed. This 100 meters erosion was chosen based on an estimate of the maximum likely error in the relative geo-referencing.

The spectral unmixing was carried out in ENVI, a type of mapping method that generates fuzzy classifications. To differentiate other earth materials from vegetation, signatures were created for salt, sand, rock and water. Classifications were then generated for Kel Tamasheq place names. After the first run, salt and sand classifications were merged together as they displayed similar spectral signatures. Recognizing that other vegetation

${ }^{17}$ Brousse tigré is a French term used to describe the phenomenon of forests that appear as a tiger's stripes from the air. This is a common occurrence in the upper latitudes of the Sahel. 
species are very likely influencing the spectral signature and that phenological factors may also influencing radiance, the results, none-the-less, were surprising. The Kel Tamasheq place names were distinct in their spectral signatures. Abutilon, Boscia, Calotropis, and Maerua registered the highest reflectance of the spectral signatures. Acacias, Andropogon and Ziziphus were moderate in reflectance and Panicum, Tribulus and Balanites were low in reflectance of the spectral signatures.

The 30 Kel Tamasheq place name maps created for the December 1986, December 2006 and FebruaryMarch 2007 were then combined in a layer stacking operation for organization and to proceed in temporal comparisons. The Kel Tamasheq place name maps were then differenced. February-March 2007 maps were subtracted from the December 2006 maps to generate seasonal comparisons while the December 2006 maps were subtracted from the December 1986 maps to produce twenty year comparisons. For the seasonal comparisons, negative changes are likely to indicate less green vegetation for the region, possibly due to phenological change or land use practices. Positive values suggest a greening between the cold season to the hot-dry season which may come from different phenological cycles or intensive land use practices such as the planting of additional crops along the fringes of retreating water. The twenty year comparisons will likely not be influenced so much by phenological variances between species but instead, influenced by inter-annual rainfall heterogeneity or changes in land use. Finally, after differencing the maps, the polygons for Kel Tamasheq place names were employed as regions of interest into ENVI to calculate statistics regarding vegetation trends. The generated statistics for Kel Tamasheq place names were added into an ArcMap 9.2 database to generate visual representations of the quantitative vegetation change for each and to save for future investigation.

\section{Results}

Generalizations Regarding Kel Tamasheq place names

The change detections revealed two distinct areas of a changing spatial pattern of vegetation : one sub-region where larger settlements, both sedentary and pastoralists, live near or on the banks of the Niger River, and another drier, remote sub-region that customary pastoralists circulate to feed and water their herds. In regards to the IGN maps, Ansongo, Gao, Gao Est and In Tillit represent the more populated areas while the maps of Ouaritoufoulout, Tegôrast, Telataï, Ténîkert and Tidarmène represent the less populated, drier regions (see Figure 06). In the seasonal comparison, the differencing between February-March 2007 and December 2006, the fuzzy memberships, in general, revealed a negative relationship for the Kel Tamasheq place names near the Niger River and a subtle positive relationship at the drier Kel Tamasheq place names. It is likely phenological processes are responsible for these differences, where vegetation near the river may have earlier flowering, fruiting, and shooting leaves stages while vegetation located at the drier regions bloom later. Land use practices may also have a role in the negative readings, but the pruning of trees and exploitation of wild foods contributes only to short-term modifications. Vegetation resources are most likely to rebound during the next rainy season.

The twenty year comparison, the differencing between December 2006 and December 1986, indicated the inverse of observations for the seasonal comparison. The Kel Tamasheq place names located near the more populated areas of Ansongo, Gao, Gao Est and In Tillit, for the most part, had positive fuzzy memberships while the Kel Tamasheq place names at Ouaritoufoulout, Tegôrast, Telataï, Ténîkert and Tidarmène had negative ones. In 
fact, large negative fuzzy memberships were observed for the Kel Tamasheq place names located at In Tebezas, Telataï and Tidarmène regions (see the individual observations for Balanites and Andropogon below). Although meteorological data is limited, it is likely climatic events are influencing these observations. In addition, land use may have a role, much larger than with the seasonal comparison. Land cover conversions such as converting pasture to agriculture may be influencing positive fuzzy memberships at the Kel Tamasheq place names near the more populated regions. Negative fuzzy memberships in the twenty year comparison may be due to demands for fuel wood and construction materials. Pastoralists, too, may have a role in this through animals overgrazing and trampling vegetation resources located near wells for the Kel Tamasheq place names at the drier regions. It is too soon, however, to add anthropomorphic causes to what appears as biophysical factors affecting the vegetation changes in the remote parts of the study area.

Statistically eight of ten of the Kel Tamasheq place names revealed in the twenty year comparison a quantitative increase of vegetation at Kel Tamasheq place names near populated zones and quantitative decrease at Kel Tamasheq place names in the drier regions. The two that did not were Acacias and Panicum, although Panicum's sampling was not as robust as other Kel Tamasheq place names. Kel Tamasheq place names for trees were the most sampled with an average sampling of 16768.8 hectares per species. Kel Tamasheq place names for grasses were second in average sampling, 12742.07 hectares, though it should be noted that the sampling for Andropogon was large and Panicum was small. Herbs were third with an average sampling of 9427.28 hectares and shrubs were the lowest average sampling with 6465.96 hectares per species.

Six colors were assigned to symbolize the changes observed through the fuzzy memberships. Positive fuzzy memberships have the colors chartreuse ( 0.0001 to 0.9999$)$, green (1 to 1.999$)$ and white ( 2 or higher) assigned to them. Negative fuzzy memberships have the colors pink (-0.0001 to -0.9999$)$, red (-1 to -1.9999$)$ and black (-2 or lower). The largest positive fuzzy membership of a Kel Tamasheq place name, 3.6654, observed for Balanties Telataï at $16^{\circ} 13^{\prime} 34.93^{\prime \prime} \mathrm{N} ; 1^{\circ} 32^{\prime} 42.18^{\prime \prime}$ E was also the largest negative fuzzy membership, -9.290924 , in the twenty year comparison. This Kel Tamasheq place name in addition to others in the regions of Gao Est, Telataï and Tidarmène are provided in Figures 09 through 12 below.

01. Observations for Kel Tamasheq place names: Acacia (ehrenbergiana, seyal and stenocarpa)

21 polygons were digitized to represent the Kel Tamasheq place names Oraf, Orof, Tamat, and Temeut, for a total coverage of 17045.01 hectares. Out of the 88 polygons digitized, this was the largest number of polygons used to represent Kel Tamasheq place names. In the seasonal comparison, the Kel Tamasheq place names for Acacias had subtle negative fuzzy memberships. This is expected considering the phenology of these tree species. Leafing and flowering occurs from October to December with leaves dropping by the start of the hot-dry season (Guinko, 1992). Larger negative fuzzy memberships were observed for Kel Tamasheq place names near the city of Gao and villages along the Niger River. Causes for this may include biophysical conditions and less likely anthropogenic factors. Proximity to more populated zones makes land use possible though difficult to distinguish from natural change. Many interviewees from this region (both Kel Tamasheq and other ethnic groups) collect wood for charcoal production and hire herders to shepherd their animals to pasture surrounding settlement areas (Author Interviews, January 2007b and April 2007b). 
Figure 09: Landsat TM mosaic subset for the area of Gao Est, Seasonal Comparison

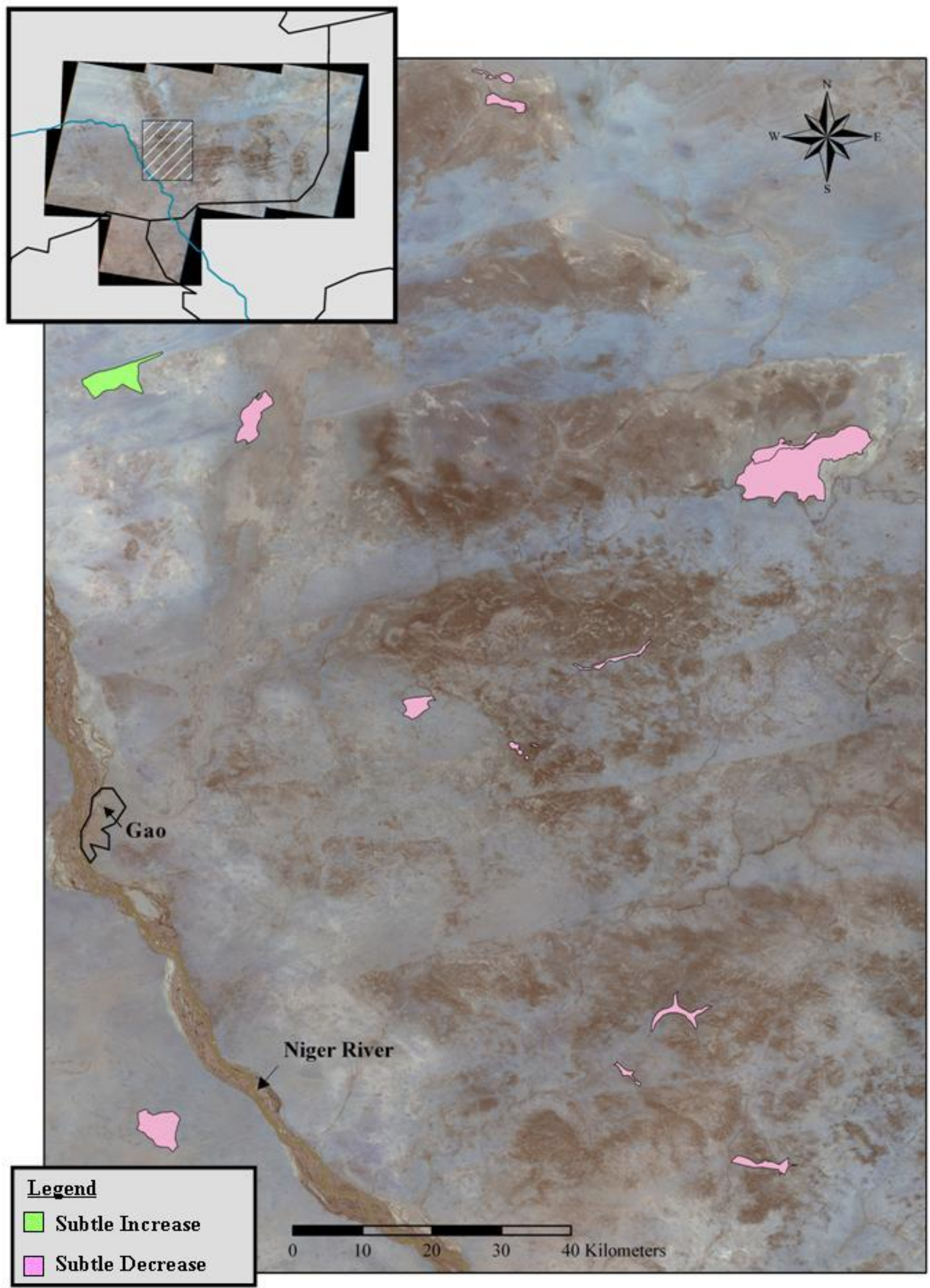

Data was generated using ENVI's Linear Spectral Unmixing mapping method in ENVI 4.7 C2010, while maps were created in ArcMap 9.2 (C2008. 
Figure 10: Landsat TM mosaic subset for the area of Gao Est, Twenty Year Comparison

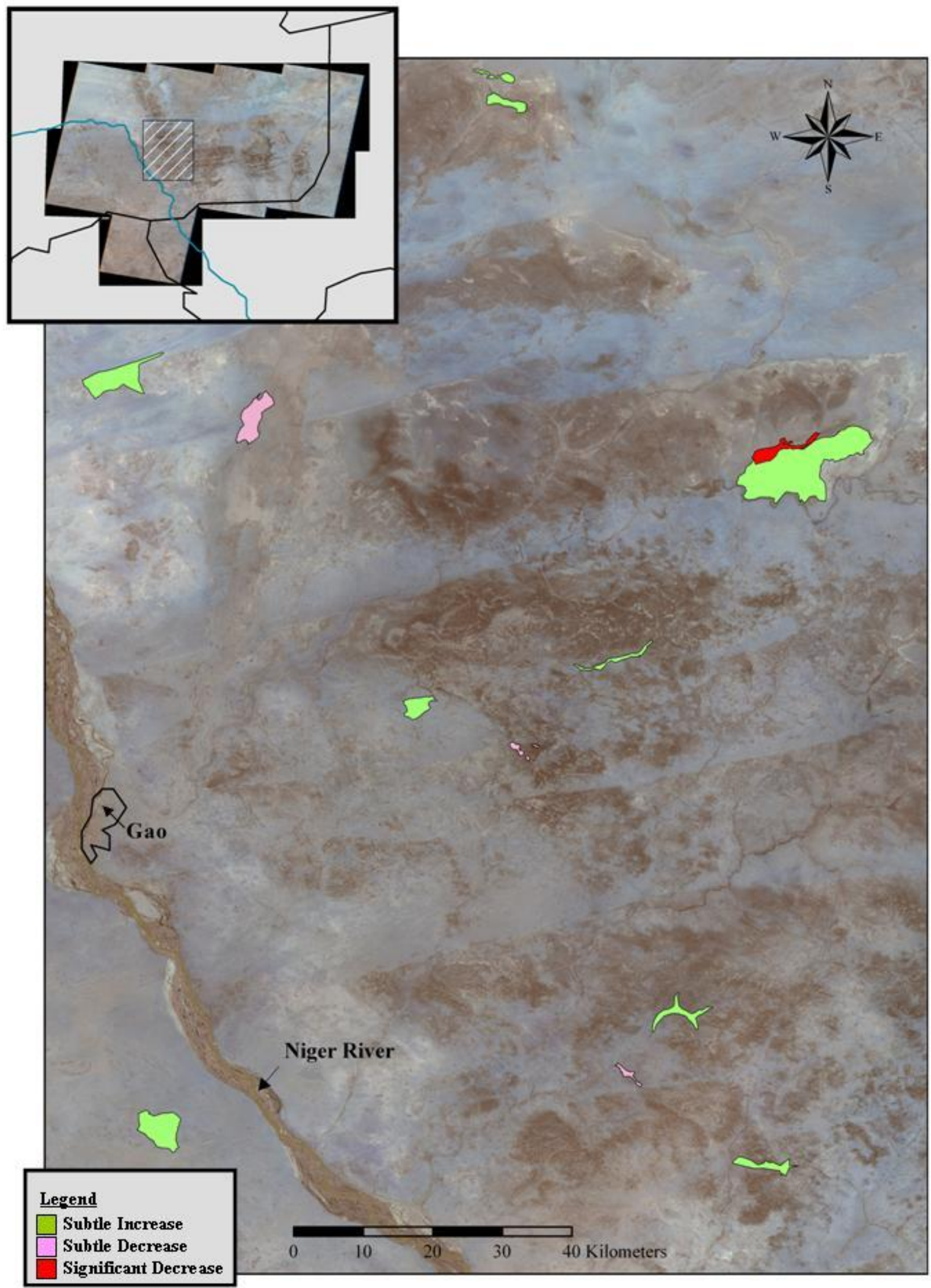

Data was generated using ENVI's Linear Spectral Unmixing mapping method in ENVI 4.7 @2010, while maps were created in ArcMap 9.2 (C2008. 
The twenty year comparison showed positive fuzzy memberships for Kel Tamasheq place names of Acacias for the eastern part of the study area, like In Tebezas, Ménaka and Tidarmène, although Acacias Tidarmène located at $16^{\circ} 28^{\prime} 08.30^{\prime \prime} \mathrm{N} ; 2^{\circ} 40^{\prime} 14.55^{\prime \prime}$ E indicated the largest negative reading for all 21 samples with -1.5662 (see Figure 12). A possible cause for this may involve the semi-sedentarization of the Inchidanaren. Some during the drought of 1983-1985 settled around the wells and established permanent homes, although many continue to leave for part of the year to exploit pastures and other natural resources to the North and South (see Chapter Three above). Kel Tamasheq place names of Acacias, in general had negative fuzzy memberships for the western part of the study area with Acacias Gao Est at $16^{\circ} 47^{\prime} 06.52$ ” N; $0^{\circ} 52^{\prime}$ '27.13” E having the largest negative change at -1.3296 (see Figure 10). Acacias was the only tree species that did not show increases in fuzzy memberships near the more populated areas in the twenty year comparison.

02. Observations for Kel Tamasheq place names: Maerua crassifolia Eight polygons were digitized to represent the Kel Tamasheq place names Adiar, Agar and Ajarr, for a total coverage of 10636.29 hectares. The number of polygons and the amount of coverage are average compared to the other Kel Tamasheq place names in this investigation. The seasonal comparison revealed subtle but distinguishable differences between the more populated areas compared to those of the drier regions in the study area. The drier regions, In Tebezas, Tegôrast and Tidarmène, indicated positive fuzzy memberships while negative fuzzy memberships were observed for the more populated regions of Ansongo and Gao Est. This spatial variation is likely a sign of different phenology or biophysical conditions influencing the growth or retardation of species. For instance, it is common for regions like In Tebezas, Tegôrast and Tidarmène, where clay deposits exist, for temporary ponds to form during the rainy season. As time passes and water evaporates or sinks underground, the soil's biophysical properties change, in some situations promoting the germination of certain flora (Demangeot and Bernus, 2001). The spatial pattern of decrease in the populated zones and increase in the drier region of the study matches the general trend observed for most of the Kel Tamasheq place names.

The twenty year comparison for the Kel Tamasheq place names for Maerua, however, differ from the Acacias' readings as minute, positive fuzzy relationships were observed for Kel Tamasheq place names near large populations and negative fuzzy relationships were observed for drier regions, in particular Tegôrast and Tidarmène. The Kel Tamasheq place names for Maerua, in addition to the majority of Kel Tamasheq place names indicate this trend of positive fuzzy memberships for place names near the Niger River and negative fuzzy memberships at the drier regions of north-eastern Mali in the twenty year comparison. If this observation is representative of vegetation change for the region, questions arise over the causal factors for this trend. Climate variability has been shown to influence the promotion and retardation of vegetation (Hermann et al, 2005; Olsson et al, 2005). Perhaps rainfall has increased at the environs of the Niger River than in the drier regions of northeastern Mali, though meteorological stations along the river, Bourem, Gao and Ansongo, do not indicate this (see Figure 08). Other possibilities may include natural change like certain flora colonizing the Kel Tamasheq place names near the river while flora species in the drier regions are in the process of retreat, experiencing disease, or susceptible to pests. Land use may also be a factor in these observations with positive fuzzy memberships attributable to land conversions, more intensive land 
use and negative fuzzy memberships possibly observed because of fire control, overgrazing, and deforestation (see Generalizations Regarding Kel Tamasheq place names above).

03. Observations for Kel Tamasheq place names: Balanites aegyptiaca

Six polygons were digitized to represent the Kel Tamasheq place names Taboraq and Tiboraq, for a total coverage of 17045.01 hectares. The number of polygons is small for this investigation while the area sampled is the largest of all the Kel Tamasheq place names. Furthermore, Balanites Tabankort located at $17^{\circ} 52^{\prime} 36.29^{\prime \prime} \mathrm{N} ; 0^{\circ} 23^{\prime} 39.79^{\prime \prime}$ E is over 13000 hectares, thus the polygons for each Kel Tamasheq place name for Balanites are unequal in size. Balanites aegyptiaca is also a desert flora (Chenoune, 2005). Its distribution in regards to the Kel Tamasheq place names is confined to the drier regions of north-eastern Mali. In the seasonal comparison, fuzzy memberships varied in positive and negative readings with Balanites Telataï at $16^{\circ} 13^{\prime} 34.93^{\prime \prime} \mathrm{N} ; 1^{\circ} 32^{\prime} 42.18^{\prime \prime}$ E having the largest positive reading, 3.6654, for the $88 \mathrm{Kel}$ Tamasheq place names. The only other Kel Tamasheq place name to have such large positive readings in fuzzy memberships for the seasonal comparison is the Kel Tamasheq place names for Andropogon laniger (see below).

Unusually large negative readings were also observed in the twenty-year comparison. Ironically, the largest, positive fuzzy membership reading for the $88 \mathrm{Kel}$ Tamasheq place names, Balanites Telataï at $16^{\circ} 13^{\prime}$ 34.93 ” N; $1^{\circ} 32^{\prime} 42.18^{\prime \prime} \mathrm{E}$ in the seasonal comparison, is also the largest, negative fuzzy membership of all $88 \mathrm{Kel}$ Tamasheq place names with a reading of -9.2909 . Balanites In Tebezas located at $17^{\circ} 15^{\prime} 07.27^{\prime \prime} \mathrm{N} ; 1^{\circ} 17^{\prime} 46.49^{\prime \prime} \mathrm{E}$ also had a positive fuzzy membership reading in the seasonal comparison and large negative reading for the twenty year comparison with -6.1189. Perhaps such bipolarity is an indication of vegetation stands where many of the trees have died off from age or disease after 1986, while observations in the seasonal comparison are indicating the growth of new trees. It is possible that land use is influencing these readings as well, though both of these locations are not near major settlements.

04. Observations for Kel Tamasheq place names: Ziziphus (lotus and mauritania)

Twelve polygons were digitized to represent the Kel Tamasheq place name of Tabakat, for a total area of 10541.07 hectares. The number of polygons is robust for the sampling while the coverage area is average for all Kel Tamasheq place names. In the seasonal comparison, fuzzy membership readings were minimal and fit the general trend of many Kel Tamasheq place names. Kel Tamasheq place names for Ziziphus in the more populous regions of the study area were negative while positive readings were observed for the regions of Telataï and Ouaritoufoulout.

Twenty year comparisons were also subtle but conforming to the general trend. Ziziphus In Tillit located at $15^{\circ} 29^{\prime} 25.21^{\prime \prime} \mathrm{N} ; 0^{\circ} 29^{\prime} 47.50^{\prime} \mathrm{W}$ had the largest positive fuzzy membership for the Ziziphus place names with 1.7817. In general, other Kel Tamasheq place names in the more populated areas like Ansongo and Gao also had positive fuzzy memberships. The largest negative fuzzy membership reading, -1.0698, was observed for Ziziphus Telataï at $16^{\circ} 16^{\prime} 20.56^{\prime \prime}$ N; $1^{\circ} 58^{\prime} 50.13$ ” E. Much like other Kel Tamasheq place names, other Kel Tamasheq place names for Balanites at Telataï and Ouaritoufoulout had negative fuzzy membership readings. 
05. Observations for Kel Tamasheq place names: Boscia senegalensis

Six polygons were digitized to represent the Kel Tamasheq place names of Tadan, Tadant, Tadhant and Tadomet, for a total area of 5675.76 hectares. The number of polygons and area investigated for Boscia is small, like other Kel Tamasheq place names for Calotropis, Tribulus and Panicum. Given the Kel Tamasheq place names for Boscia identified in this study, however, the seasonal comparison matched the general trends of many Kel Tamasheq place names: positive readings for the Kel Tamasheq place names near the Niger River; negative readings for those located at the drier regions of north-eastern Mali.

It was observed in the twenty year comparison that fuzzy memberships were subtle in readings but that the general trend of positive readings for Kel Tamasheq place names at the more populated regions and negative readings for those at the drier regions of north-eastern Mali was observed. The Kel Tamasheq place name of Boscia Gao at $16^{\circ} 36^{\prime} 34.58^{\prime \prime} \mathrm{N} ; 0^{\circ} 32^{\prime} 09.71^{\prime \prime} \mathrm{W}$ had the largest positive fuzzy membership, 0.9019 , while negative fuzzy memberships were observed for Boscia Ménaka at $15^{\circ} 50^{\prime} 26.58^{\prime \prime} \mathrm{N} ; 2^{\circ} 41^{\prime} 01.47^{\prime \prime}$ E (-0.5451) and Boscia Ouaritoufoulout at $16^{\circ} 26^{\prime} 14.61$ ' N; $3^{\circ} 57^{\prime} 44.21^{\prime \prime}$ E (-0.8577).

06. Observations for Kel Tamasheq place names: Calotropis procera

Five polygons were digitized to represent the Kel Tamasheq place names of Talza, Tirza, Torcha, Torsa, and Toulza, for a total area of 7256.16 hectares. The number of polygons is small compared to other Kel Tamasheq place names sampled, although the area coverage is larger than the Kel Tamasheq place names for Boscia, Tribulus and Panicum. Much like the situation of Kel Tamasheq place names for Balanites where one polygon is dominant for a large part of the sampled area, Calotropis also has an unusually large polygon, Gao at $16^{\circ} 11^{\prime} 19.24^{\prime \prime}$ N; $0^{\circ} 56^{\prime} 35.97^{\prime \prime}$ W, covering nearly 3200 hectares of the sampled area. Unlike the Kel Tamasheq place names for Balanites, however, five out of six of Kel Tamasheq place names for Calotropis are located at the more populous regions near the Niger River. In the seasonal comparison, trends were consistent with other Kel Tamasheq place names. The Kel Tamasheq place name for Calotropis at Ménaka $15^{\circ} 48^{\prime} 46.83^{\prime \prime} \mathrm{N} ; 2^{\circ} 25^{\prime} 19.94$ " E had a small, negative fuzzy membership while a positive fuzzy membership reading was observed for Ténîkert at $17^{\circ} 47^{\prime} 25.12^{\prime \prime}$ N; $3^{\circ} 59^{\prime} 58.83^{\prime}$ " E. This observation, once again, is believed to be variance in spatial phenology, where flora from the more humid regions experience 'greenness' in the months of October through December, while the same species in drier regions experience flowering, fruiting and shooting of leaves in the months of January through March.

Trends were not large in the twenty year comparison but remained consistent with the majority of many of the $88 \mathrm{Kel}$ Tamasheq place names where the one Kel Tamasheq place name for Calotropis in the drier regions of the study, Ténîkert at $17^{\circ} 47^{\prime} 25.12^{\prime \prime} \mathrm{N} ; 3^{\circ} 59^{\prime} 58.83^{\prime \prime} \mathrm{E}$, had a negative fuzzy relationship while the others for the more populated areas of Gao, In Tillit and Ménaka showed small, positive fuzzy memberships. These particular Kel Tamasheq place names were not visited at the time of this research although some interviewees at Gao and Ménaka complained about the colonization of Calotropis procera at pastures they have exploited over the past two decades (Author Interviews, February 2007a and April 2007b). The remote sensing data and the data revealed at interviews calls into question the factors promoting the growth of Calotropis procera near the more urban areas, if they are biophysical, anthropogenic or both. 
Figure 11: Landsat TM mosaic subset for the area of Telataï and Tidarmène, Seasonal Comparison

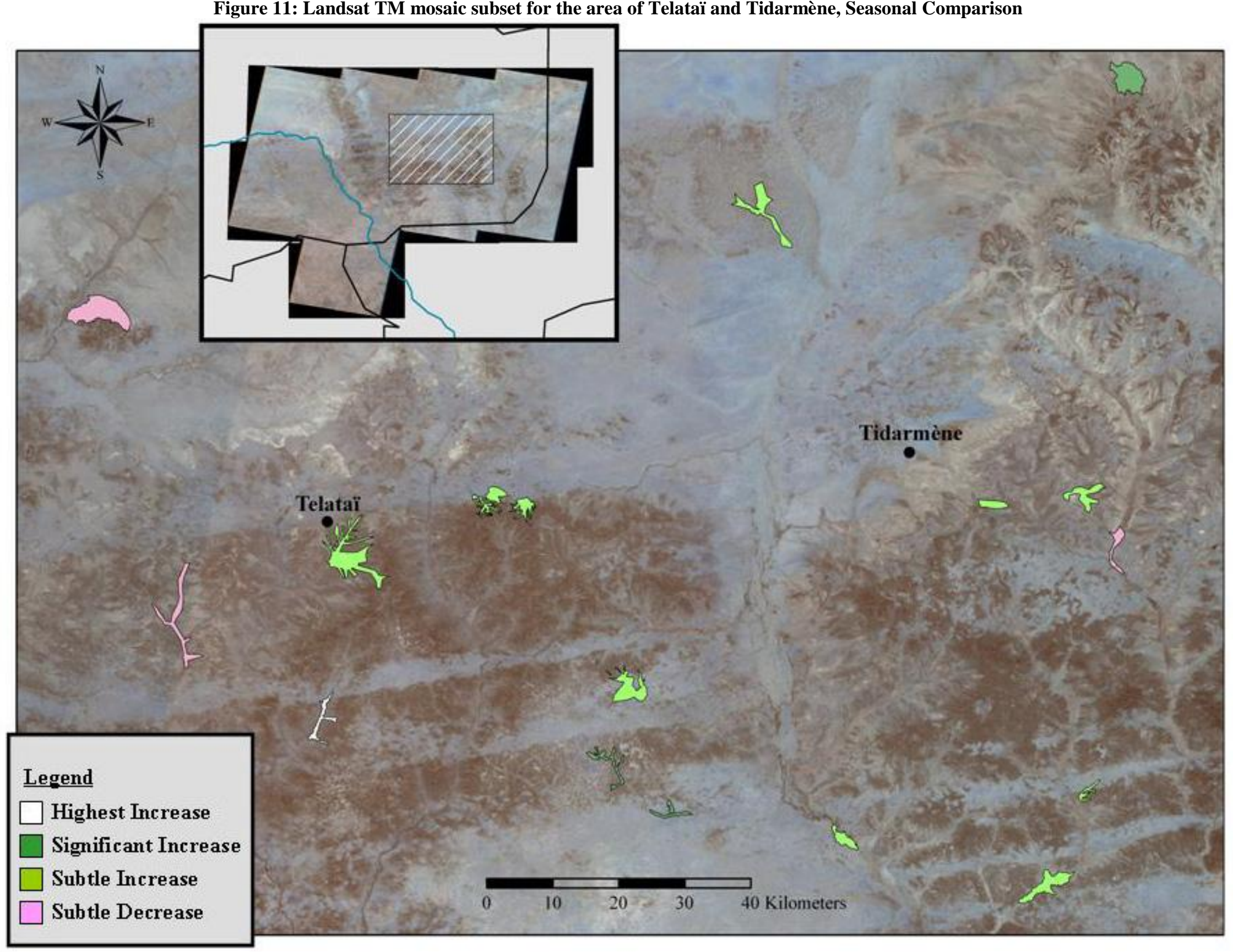

Data was generated using ENVI’s Linear Spectral Unmixing mapping method in ENVI 4.7 (C2010, while maps were created in ArcMap 9.2 @2008. 
Figure 12: Landsat TM mosaic subset for the area of Telataï and Tidarmène, Twenty Year Comparison

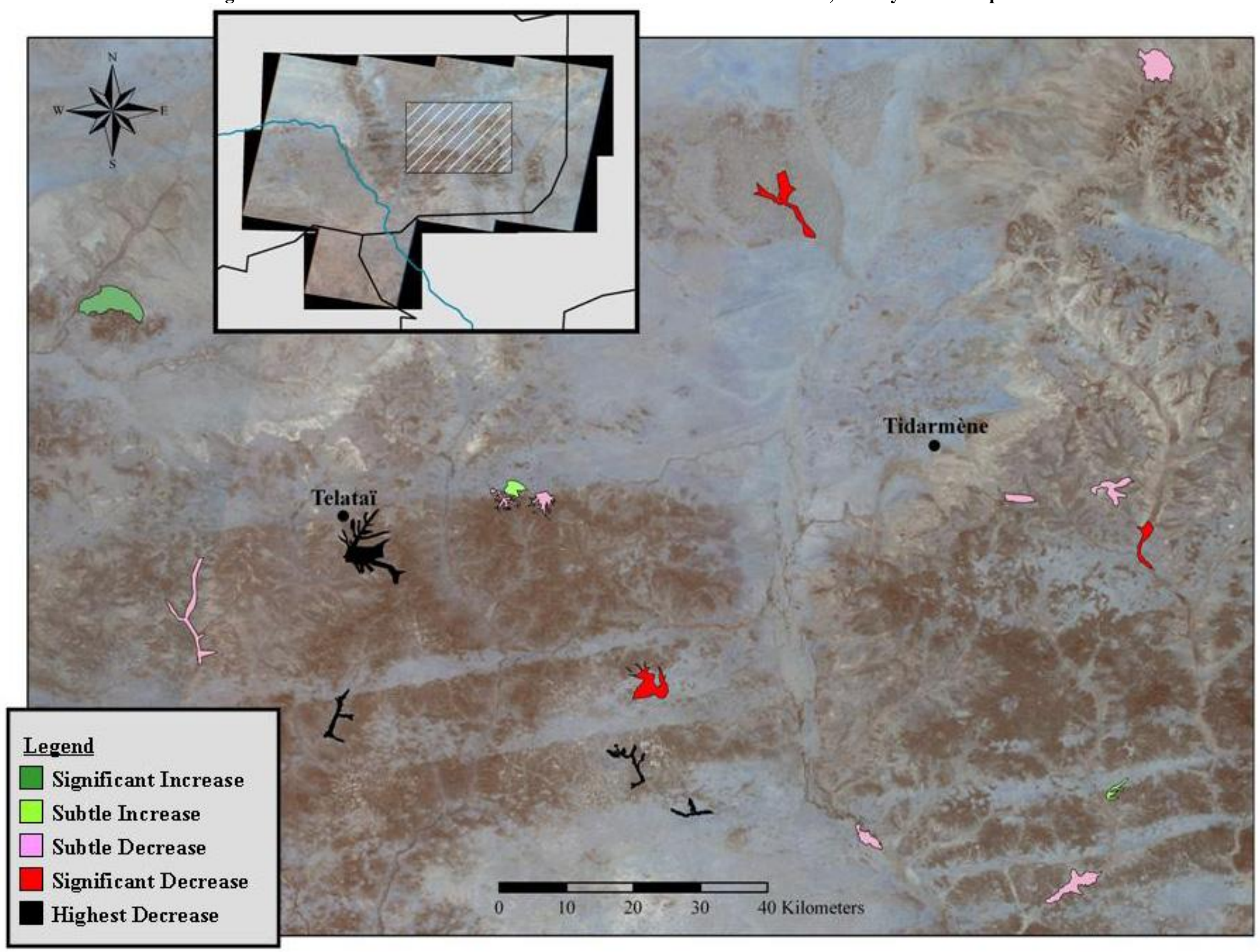

Data was generated using ENVI’s Linear Spectral Unmixing mapping method in ENVI 4.7 @2010, while maps were created in ArcMap 9.2 @2008. 
07. Observations for Kel Tamasheq place names: Abutilon pannosum

Thirteen polygons were digitized to represent the Kel Tamasheq place names of Afarak, Aguersman, and Esab for a total area of 15501.87 hectares. This was the second largest number of polygons sampled for all Kel Tamasheq place names with area coverage the second largest of non-tree species sampled. Subtle fuzzy membership readings were observed in the seasonal comparison. Kel Tamasheq place names near populated areas like Ansongo had negative fuzzy memberships while the drier regions of Tegôrast and Telataï had positive fuzzy memberships. Once again, it is likely the biophysical differences between humid and dry regions in the study area are influencing different cycles of phenology for Abutilon pannosum at the Niger River and drier regions.

Moderate to large readings were observed for the twenty year comparison. Moderate, positive fuzzy memberships were observed for Kel Tamasheq place names near the Niger River like Ansongo at $15^{\circ} 28^{\prime} 07.55^{\prime \prime} \mathrm{N}$; $0^{\circ} 50^{\prime} 16.24$ " E (0.5158), and also for some of the Kel Tamasheq place names in drier regions like In Tebezas at $17^{\circ}$ $40^{\prime} 10.74^{\prime \prime} \mathrm{N} ; 1^{\circ} 11^{\prime} 37.09^{\prime \prime} \mathrm{E}(0.7498)$ and Tegôrast at $17^{\circ} 50^{\prime} 01.87^{\prime \prime} \mathrm{N} ; 2^{\circ} 49^{\prime} 25.03^{\prime \prime} \mathrm{E}$ (0.8734). However, this was not the case for all Kel Tamasheq place names for Abutilon in the drier regions of the study. Large negative fuzzy memberships were observed for Tidarmène located at $16^{\circ} 55^{\prime} 37.39^{\prime}$ N; $2^{\circ} 10^{\prime} 04.95^{\prime \prime} \mathrm{E}$ with a reading of 1.9696 and Telataï located $16^{\circ} 27^{\prime} 04.67^{\prime \prime} \mathrm{N} ; 1^{\circ} 35^{\prime} 04.87^{\prime}$ ' E with a reading of -2.0559 (see Figure 12). As mentioned in the twenty year comparison of Kel Tamasheq place names for Balanites, this may be a region where disease, age or deforestation is contributing to the observations of negative fuzzy memberships for some Kel Tamasheq place names in the drier regions of the study area.

08. Observations for Kel Tamasheq place names: Tribulus terrestris

Five polygons were digitized to represent the Kel Tamasheq place names of Adjorof, Agerof, Aguerof and Tajaroft, for a total area of 3352.68 hectares. The number of polygons and area investigated for Tribulus is small for the study, only larger than Panicum in number of polygons and area coverage. Despite the small sampling, the seasonal comparison follows the general trend of negative fuzzy membership readings for the Kel Tamasheq place names like Ansongo, one of the regions near the Niger River, and positive readings for the more remote regions like Ouaritoufoulout.

The twenty year comparison also followed the general trend. A moderate, positive fuzzy membership

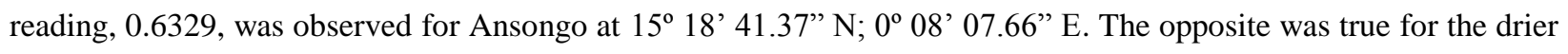
Kel Tamasheq place names for Tribulus, with readings of -0.2859 for Ouaritoufoulout $16^{\circ} 42^{\prime} 50.96^{\prime}$ N N $3^{\circ} 22^{\prime}$ 24.01 ” E and -0.3528 for Ouaritoufoulout $16^{\circ} 42^{\prime} 49.12^{\prime \prime} \mathrm{N} ; 3^{\circ} 25^{\prime} 10.79^{\prime \prime}$ E. These readings are small but consistent with the general observations of other Kel Tamasheq place names for the twenty year comparison

09. Observations for Kel Tamasheq place names: Andropogon laniger

Eight polygons were digitized to represent the Kel Tamasheq place name of Teberemt, for a total coverage of 24424.11 hectares. Like the Kel Tamasheq place name for Balanites, the number of polygons is relatively small while the area coverage is large, the second largest of the Kel Tamasheq place name species. Like Balanites and Calotropis, there is one polygon within the data set for Andropogon that is larger than the others. Gao located at $16^{\circ}$ $49^{\prime} 04.75^{\prime \prime} \mathrm{N} ; 0^{\circ} 10^{\prime} 01.47^{\prime}$ E is over 10000 hectares, consisting of $40 \%$ of the total area coverage sampled for Andropogon (see Figures 09 and 10). In the seasonal comparison, Andropogon Tidarmène located at 16 $06^{\prime}$ 12.80" 
N; $2^{\circ} 02^{\prime} 21.11^{\prime \prime}$ E had a large, positive fuzzy membership of 1.2184 and Andropogon Telataï located at $16^{\circ} 10^{\prime}$ 10.49 ” N $1^{\circ} 57^{\prime} 08.41$ ” E also had a large, positive reading of 1.6007 (see Figure 11).

For the twenty year comparison subtle, positive readings were observed for the Kel Tamasheq place names for Andropogon at the more populated areas while large, negative readings were observed fort the drier regions. Gao, at $16^{\circ} 49^{\prime} 04.75^{\prime \prime} \mathrm{N} ; 0^{\circ} 10^{\prime} 01.47^{\prime \prime} \mathrm{E}$, had a positive fuzzy membership of 0.7020 , while Tidarmène $16^{\circ} 06^{\prime}$ $12.80^{\prime \prime} \mathrm{N} ; 2^{\circ} 02^{\prime} 21.11^{\prime \prime} \mathrm{E}$ and Telataï $16^{\circ} 10^{\prime} 10.49^{\prime}$ N; $1^{\circ} 57^{\prime} 08.41^{\prime}$ E, had readings of -9.0802 and -4.1809 respectively (see Figure 12). The large, positive fuzzy memberships in the seasonal comparison and the large, negative fuzzy memberships in the twenty year comparison are similar to those indicated in the observations of Kel Tamasheq place names for Balanites. If it is not coincidence that these two Kel Tamasheq place names have similar readings, then a question arises about the relationship this annual grass species, Andropogon, may have with the perennial tree species, Balanites.

\section{Observations for Kel Tamasheq place names: Panicum laetum kunth}

This was the poorest sampling: two polygons were digitized to represent the Kel Tamasheq place names of Akasof, Allon, Asghal, and Isihiban, for a total area of 1060.02 hectares. Part of the difficulty lies in where and when Panicum laetum kunth is found, typically on the banks of river channels when the waters recede immediately after the rainy season (Maiga et al, 1991). Since it is common to find other vegetation resources in proximity to the river banks, the Kel Tamasheq may call localities where Panicum is found by other names designating other resources, like Acacias or Maerua. Another concern is this particular flora is more commonly found in the more humid parts of the Sahel (Aune, 1991; Maiga et al, 1991). Despite the small sampling, the two Kel Tamasheq place names for Panicum, Gao Est at $16^{\circ} 30^{\prime} 42.27^{\prime \prime} \mathrm{N} ; 0^{\circ} 39^{\prime} 38.83^{\prime \prime}$ E and Tabankort at $17^{\circ} 39^{\prime} 14.46^{\prime \prime} \mathrm{N} ; 0^{\circ} 40^{\prime} 17.45^{\prime}$ E, had small, negative fuzzy memberships for the seasonal comparison and small, positive fuzzy memberships for the twenty year comparison. Theses two Kel Tamasheq place names, however, are only representative of vegetation stands near the Niger River.

\section{Conclusion: Areas for Further Research}

Within the limits of the study's data, further investigation is possible through the sampling of pixels within the polygons of the Kel Tamasheq place names. This sub-sampling method is especially useful for inquires with plant species like the grasses, Andropogon laniger and Panicum laetum kunth. Andropogon tends to grow on the sides of dunes more so than depressions or flat plains of sand (Some et al, 2007). Panicum grows on the banks of wadis or temporary ponds as opposed to the deeper channels or depressions formed by water bodies (Aune, 1991). Subsampling allows the ability to unravel the heterogeneity that exists within the Kel Tamasheq place name polygons.

Qualitative data regarding local observations of climate and vegetation change at the Kel Tamasheq place names will provide a more in depth analysis of the causal factors contributing to the observed readings in the remote sensing data. The results in this study, however, provide some direction into the vegetation dynamics of northeastern Mali. If the fuzzy membership readings are representative of the vegetation change occurring for the investigated area, inquiries into the spatial distinction observed for the humid regions of the Niger River and that of the drier, remote regions are needed. This will likely have some challenges as various actors are likely to use the 
flora at a $\mathrm{Kel}$ tamasheq place name during different seasons. There is also the challenge of identifying long term natural changes that may influence the readings. The combination of phenological, climate, other biophysical, and land use studies for the two sub-sets from this study area can contribute to a better understanding of the promotion, maintenance, or retardation of vegetation in north-eastern Mali and, using in other Saharan and Sahelian vegetation studies when appropriate.

Detailed botanical investigations of the Kel Tamasheq place names from this study will provide researchers qualitative data regarding the plant species present at these sampled areas. It will also reveal the logic of Kel Tamasheq place name assignments to the vegetation stands or, if the flora is absent, the historical changes for flora in the region. The likeness of readings for flora, like Balanites and Andropogon, if accurate and not coincidental, may reflect a symbiotic relationship between the two where Andropogon may occupy the Kel Tamasheq place name for Balanites and vice versa. Vegetation stands, essentially what the Kel Tamasheq place name polygon is meant to represent, are commonly not one, homogenous species in the Sahel or Sahara. A better understanding of their plant dynamics, in addition to other earth materials present and biophysical properties affecting vegetation patterns, can foster a better understanding of the observations made in this change detection study. 


\section{Chapter 5: Conclusion No Direction is certain until the Path is walked Pastoralists and their future in the Sahara and Sahel}

The interview discussed at the beginning of this dissertation, Boubaker Ag Ghali's proposing a 'path of development' for pastoral groups to take in the Aïr Region of Niger, is but one of many paths proposed in pastoral development. To recall his position, he called for the privatization of land, the sedentarization of pastoralists, and then the allotment of land, farming and ranching implements to sedentarized pastoralist families in order for them to subsist off of the natural resources present on their newly acquired property. This dissertation has shown that such a path has practicality for only a fraction of pastoralists, and even more specific to pastoralists who inhabit the more humid southern latitudes of the Sahel, when accounting for the variability of resources in the Sahara and northern Sahel. Even if Ag Ghali's development path came to fruition, it is hardly complete in safeguarding pastoralists from vulnerability when drought, market crashes, flooding, banditry, or other types of catastrophes occur. Development in the region is as complicated and fragmented as pastoral society itself in the Aïr Region, and certainly for other groups, both pastoral and non-pastoral, in the other regions of West Africa.

Pastoral-state relations along with aid organizations, multinational corporations, Western militaries, and extremist groups are far from understanding the challenges pastoral groups face in the southern Sahara and northern Sahel partially because they adopt a crisis narrative when dealing with pastoral groups, and also because their own agendas commonly conflict with (and take precedence over) pastoral-state integration and the alleviation of poverty in then region. The archival data showed the ebbs and flows of colonial intentions and practice, where colonial officials viewed pastoralists as a belligerent, medieval society that needed to be subjugated. After doing so, opinion and policy shifted to the romantic idea of preserving pastoralists on reservations distant from colonial life. Limited budgets that called for colonies to pay for themselves assured that pastoralists were left alone, but pastoralists did more than tend to animals far from colonial life. Some, if possible, reconfigured their social relations with sedentary groups, others moved into the informal trading networks that were created between rival colonial powers, and as

long as the rains were favorable, individuals that were excluded from animal husbandry before then became pastoralists. The interviews showed that the droughts of the 1970s and 1980s reversed this trend, and in fact, fragmented pastoral groups into different livelihoods, environments, and strategies. The unidirectional path that governemnts and NGOs promoted among these fragmented groups were adopted by a few, manipulated by some, and evaded by many. A participatory role for pastoralists in development came with state and NGO reforms in the 1990s, but this has its shortcomings and has also been pushed aside for the Western powers agenda of GWOT. Throughout West Africa, the violence that Special Forces and terrorists bring with them is debilitating on pastoral livelihoods and creating greater conditions of state alienation and poverty.

The interviews and the application of David Harvey's 'six moments' to this data showed that despite fragmentation, pastoralists have a sense of identity and direction that many refuse to discard despite their displacement and dispossession. For some, the droughts and the rebellions were difficult but through their social position and labor, they endured and maintain their customary livelihoods. For others, particularly those who were new to pastoralism or living with great vulnerability before the droughts and civil violence, these crises pushed them 
into refugee camps or urban environments to seek out assistance and work. The incompatibility of aid projects with pastoral coping strategies, the discrimination pastoral groups experienced in cities, and the social ills of urban environments not only reinforced a sense of identity, it created antagonisms that were eventually expressed through insurgency by a young generation of Arab, Kel Tamasheq and Toubou people. Arabs and Toubou in Chad were the first break out of violence in pastoral territory during the 1960s; Arabs, Kel Tamasheq and Toubou in Mali and Niger rebelled later in the 1990s. Despite the violence and drought, some families regained their flocks and returned to pasture, although there are generations of pastoralists who did not succeed. They have accepted their misfortune but, in their parental roles, trained some if not all their children the skills needed to tend to animals in the countryside. It is too early to tell if the number of pastoralists, particularly Arab, Kel Tamasheq and Toubou, will rebound. Given the efforts of both customary and displaced-dispossessed pastoralists, however, to maintain their livelihoods and identity, it is not farfetched that pastoralism will become a viable livelihood once again; particularly if climate variability continues to impact West African populations and the chronic problems of urbanization persist.

The linkage between Kel Tamasheq place names for flora collected from the interviews and the remote sensing data detected a profound difference in vegetation resources near the Niger River and those further inland, located at the drier regions of north-eastern Mali. A seasonal comparison, February-March 2007 from December 2006, and a twenty year comparison, December 2006 from December 1986, were made. If the data and readings are representative of the vegetation changes taking place, observations in the seasonal comparison showed phenological differences exist between the two sub-regions, where vegetation near the Niger River is 'greener' in the early months of the dry season and 'greener' later in the season at the drier, remote regions. The opposite was observed in the twenty year comparison. Readings indicated a gradual increase of vegetation near the Niger River while vegetation in the drier, remote regions decreased. Whether pests, disease, the age of trees, flora heterogeneity, climate, or land use practices contributing to this change is unknown. If these changes are representative of a long term trend, however, then inquires into these causal factors are needed. Spatial variation in phenology, climate, other biophysical factors, and land use practices are invaluable to the stewardship of natural resources for the local Kel Tamasheq communities of north-eastern Mali, for the state of Mali, and for other Sahelian and Saharan nations.

As disappointing as it sounds, no one path is just or desired by pastoral groups who have experienced conflict and fragmentation for over 100 years. In the interviews, there were older ex-pastoralists who do not have the energy or desire to return to pasture but need training in farming practices and techniques so they can yield better harvests. There were older Kel Tamasheq women receiving five goats from NGOs to restock their herds who chose to starve themselves in order to buy fodder for the newly acquired animals. There were also middle-aged Arab men who were slowly rebuilding their flocks yet frustrated that camels were not available through NGO projects or at their local animal market. And there were pastoralists who fled when viewing a stranger, fearing that contact would 'poison' them or their animals. Thus, it is imperative that development involves pastoralists themselves, the options available are many and compatible with pastoral internal logic, and that the expectation of reaching large numbers of pastoralists is abandoned for the more pressing needs of integrating pastoral groups into their countries and reducing the problems of poverty throughout the southern Sahara and northern Sahel. 


\section{SOURCES CITED}

Abaye O., El Hadj, M., Kodio, A. and Keïta, M. (2005). Controlled Grazing: Botanical Response and Animal Performance, Conflict, Social Capital and Managing Natural Resources 2005: 211-227.

Adepoju, A. (2006). The Challenge of Labour Migration Flows between West Africa and the Maghreb, International Migration Papers 84E (Geneva: International Labor Office), 45 p.

African Research Bulletin (2008). 'Tougher Stance on Touareg Rebels,' 45 (6): 17577.

Ag Sidiyene, E. (1996). Des Arbres et des arbustes spontanés de l'Adrar des Iforas (Mali) (Paris: Organisation de la Recherche Scientifique et Technologie d'Outre Mer).

Agnew, C.T. (1990). Spatial aspects of drought in the Sahel, Journal of Arid Environments 18: 279-293.

Agnew, C.T. (1995). Desertification, drought and development in the Sahel, in Binns, T. ed., People and the Envronment in Africa (New York: John Wiley \& Sons).

Agnew, C.T. and Chappell, A. (1999). Drought in the Sahel, GeoJournal 48: 299-311.

Agonyissa, D. and Sinsin, B. (1998). Productivité et capacité de charge des pâturages naturels au Benin, Revue d'elevage et de medicine veterinaire de pays tropicaux 51 (3): 239-246.

Ali, M.M., Dickinson, G., Murphy, K.J. (2000). Predictors of plant diversity in a hyper arid desert wadi ecosystem, Journal of Arid Environments 45: 215-230.

Alibert, P., Hilaire, M. et Wafy, G. (25 Octobre 1943). Note sur la situation des indigènes à Gao et au Soudan, adressée à Monsieur Pleven, commissaire aux colonies Fromentin, n. 1045. Documentation Française, Notes et Documents 0597 (06), 15 p.

Amnesty International (19 December 2007). "Niger: Extrajudicial Executions and Population Displacement in the North of the Country," (PRE01/005/2007). Available at: http://www.amnesty.org/en/for-media/press releases/niger-extrajudicial-executions-and-population-displacement-north-country.

Amnesty International (3 April 2008). "Niger: Executions and Forced Disappearances Follow Army Reprisals," (PRE01/106/2008). Available at: http://www.amnesty.org/en/for-media/press-releases/niger-executionsand-forced-disappearances-follow-army-reprisals-2008040.

Angassa, A. and Oba, G. (2008). Herder perceptions on impacts of range enclosures, crop farming, fire ban and bush encroachment on the rangelands of Borana, Southern Ethiopia, Human Ecology 36: 201-215.

Anonyme (1917). Rapport sur le siège et la délivrance d'Agades a Monsieur le ministère des colonies, Paris. Documentation Française, Notes et Documents 0539 (5), 27 p.

Anonyme (1937). Rapport Politique, 1936 du gouvernement général de l'A.O.F. Documentation Française, Notes et Documents 0539 (5), 113 p.

Anonyme (Janvier 1957). Note sur l'Organisation commune des Regions Sahariennes - (O.C.R.S.), Documentation Française, Notes et Documents 2188 (7), 3 p.

Antil, A. (2006). L'Afrique et la " guerre contre la terreur », Politique étrangère 3: 583-591.

Antoine-Moussiaux, N., Faye, B. and Vias, G.F. (2007). Tuareg ethnoveterinary treatments of camel diseases in the Agadez area (Niger), Tropical Animal Health Production 39: 83-89.

Arbonnier, M. (2009). Arbres, arbustes et lianes des zones sèches d'Afrique dl l'Ouest, $3^{\mathrm{e}}$ édition (Versailles : Quæ).

Arditi, C. (2003). Le Tchad et le monde arabe: essai d'analyse des relations commerciales de la période précoloniale à aujourd'hui, Afrique contemporaine 207 (3): 185-198.

Aremu O.T. and Onadeko, S.A. (2008). Nutritional Ecology of African Buffalo (Syncerus caffer nanus), International Journal of Agricultural Research 3 (4): 281-286.

Arnaud, R. and Cortier, M. (1908). Nos Confins Sahariens (Paris: Larose).

Asher, M. (2008). Death in the Sahara: The Lords of the Desert and the Timbuktu Railway Expedition Massacre (New York: Skyhorse Publishing).

Aune, J.B. (1991). Régénération des plaines à Panicum laetum dans le Gourma malien, Revue Elevage Médicine vétérinaire des pays tropicaux 44 (3): 363-372.

Author Interviews (December 2006). 11 community members: displaced-dispossessed herders and customary herders visiting the animal market (Gao, Mali).

Author Interviews (January 2007a). 18 displaced-dispossessed herders inhabiting temporary residences in the neighborhood of Sosso Koïra (Gao, Mali).

Author Interviews (January 2007b). 25 community members: farmers, agro-pastoralists, displaced-dispossessed herders, and investment herders in village (Tacharan, Mali).

Author Interviews (January 2007c). 9 customary herders at their encampments (Bilalkawol, Mali).

Author Interviews (January 2007d). 18 displaced-dispossessed herders inhabiting gardens at Essakan II (Ménaka, 
Mali).

Author Interviews (February 2007a). 41 community members: displaced-dispossessed herders, customary herders, and people who invest in livestock (Ménaka, Mali).

Author Interviews (February 2007b). 26 community members: customary herders, agro-pastoralists and merchants at commune environs (Tidarmène, Mali).

Author Interviews (March 2007a). 16 community members: merchants, NGO employees and civil service workers (Ménaka, Mali).

Author Interviews (March 2007b). 23 community members: customary herders and agro-pastoralists at commune environs (Tin Abao, Mali).

Author Interviews (March 2007c). 12 community members: merchants and civil servants visiting the main market (Gao, Mali).

Author Interviews (April 2007a). 8 community members: civil service workers and artisans (Emnaghuil, Mali).

Author Interviews (April 2007b). 33 displaced-dispossessed herders inhabiting temporary residences in the neighborhood of Sosso Koïra (Gao, Mali).

Author Interviews (May 2007). 22 community members: displaced-dispossessed herders, customary herders and merchants (Gao, Mali).

Author Interviews (December 2007a). 15 community members: aid workers and mine workers (Arlit, Niger).

Author Interviews (December 2007b). Aid worker manager involved in food aid and development projects in the Tahoua Region of Niger from 1984-1992 (Agadez, Niger).

Author Interviews (December 2007c). 5 merchants interviewed at market (Agadez, Niger).

Author Interviews (January 2008). 5 return interviews with displace-dispossessed herders inhabiting gardens at Essakan II (Ménaka, Mali).

Author Interviews (February 2008). 13 customary herders visiting the animal market (Djébok, Mali).

Author Interviews (May 2009). Phone interview with aid worker for the Ménaka Region of Mali during 1990-1996 (Morgantown, United States).

Azarya, V. (1996). Nomads and the State in Africa: The political roots of marginality (Surrey, UK: Ashgate).

Barchfield, J. (22 September 2010). “France's Sarkozy Calls Niger Kidnappings Worrying," Real Clear World. Available at: http://www.realclearworld.com/news/ap/international/2010/Sep/22/france_s_sarkozy calls_niger_kidnappings_worrying.html.

Baroin, C. (1981). Ecologie et organisation sociale: Comparaison des trois sociétés sahariennes (Toubou, Touarègue, Maure), Revue de l'Occident Musulman et de la Méditerranée 32: 1-18.

Barry, J-P. (1989). Le problème des divisions bioclimatiques et floristiques au Sahara, Bulletin de la Société botanique de France 136 (314): 67-84.

Bassett, T.J. (1988). The Political Ecology of Peasant-Herder Conflicts in the Northern Ivory Coast, Association of the American Geographers 90 (1): 67-95.

Bassett, T.J. and Turner, M.D. (2007). Sudden Shift or Migratory Drift? FulBe Herd Movements to the SudanoGuinean Region of West Africa, Human Ecology 35: 33-49.

Baugh, W.M. and Groeneveld, D.P. (2006). Broadband vegetation index performance evaluated for a low-cover environment, International Journal of Remote Sensing 27 (21): 4715-4730.

Baumer, M. (1981). Rôle de Bosica senegalensis (Pers.) Lam. Dans l'économie rurale africaine: sa consommation par le bétail, Revue Elevage Médicine vétérinaire des pays tropicaux 34 (3): 325-328.

Behnke, R.H., Scoones, I. and Kerven, C. eds. (1993). Range Ecology at Disequilibrium (London: Overseas Development Institute).

Benjaminsen, T.A. (1997). Is There a Fuelwood Crisis in Rural Mali? GeoJournal, 43 (2): 163-174.

Benjaminsen, T.A. (2008). Does Supply-Induced Scarcity Drive Violent Conflicts in the African Sahel? Journal of Peace Research, 45 (6): 819-836.

Berge, G. (2001). Tuareg Notions of Space and Place in Northern Mali, in Benjaminsen, T.A. and Lund, C., eds., Politics, Property, and Production in the West African Sahel; Understanding Natural Resource Management (Uppsala, Sweden: Nordic Africa Institute): 182-207.

Berge, G., Diallo, D. and Hveem, B. (2006). Les plantes sauvages du Sahel malien : Les stratégies d'adaptation a la sècheresse des sahéliens (Paris: Karthala).

Bernus, E. (1981). Touaregs Nigériens: Unité culturelle et diversité régionale d'un peuple pasteur (Paris : L'Harmattan).

Bernus, E. (1988). Seasonality, Climatic Fluctuations and Food Supplies, in De Garine, I. and Harrison, G.A. eds. Coping with Uncertainty in Food Supply (Oxford: Oxford University Press): 318-336.

Bernus, E., Boilley, P., Clauzel, J. et Triaud, J-L., dirs. (1993). Nomades et commandants (Paris: Karthala). 
Berschinski, R.G. (2007). AFRICOM's Dilemma: The “Global War on Terrorism," “Capacity Building," Humanitarianism, and the Future of U.S. Security Policy in Africa, Strategic Studies Institute Paper (Carlisle, PA: U.S. Army War College), 71 p.

Beslay, F. (1985). Les Reguibat et le Front POLISARIO, Mondes et Cultures 45 (3): 553-559.

Blench, R.M. (2001). Pastoralism in the New Millennium, Animal Health and Production Series 150 (Rome: Food Agricultural Organization), 105 p.

Boccanfuso D., Coulibaly, M., and Savard, L. (2008). Une analyse d'impacts économique et social des reformes économiques et de l'aide publique au développement au Mali - Un cadre macro-micro, The European Journal of Development Research 20 (3): 519-545.

Boëtsch , G., Claudot-Hawad, H. et Ferrié, J-N. (2004). Des touareg « sauvages » aux Egyptiens « urbains »: les gradations de l'émotion exotique, Bancel, N., Blanchard, P., Boëtsch, G., Deroo, É. et Lemaire, S., dirs., Zoos humaines : au temps des exhibitions humaines (Paris: La Découverte).

Boilley, P. (1999). Les Touaregs Kel Adagh (Paris: Karthala).

Boilley, P. (2004). Faire de la recherché en période de crise: Une « histoire de contrebande », Afrique \& histoire 1 (2): 295-302.

Bolwig, S. and Paarup-Laursen, B. (1999). Nature, Work, Culture: Labour Utilization in Agriculture and Off-farm Employment among the Fulani in Northern Burkina Faso, Geografisk Tidsskrift 2: 27-41.

Bolwig, S., Cold-Ravnkilde, S.M., Rasmussen, K., Breinholt, T., and Mortimore, M. (2009). Achieving Sustainable Natural Resource Management in the Sahel after the Era of Desertification Markets, Property Rights, Decentralization, and Climate Change, Report, Danish Institute for International Studies, Copenhagen 7 , $66 \mathrm{p}$.

Bonnier, Général (10 Octobre 1912). Commandant supérieur des troupes du groupe de l'Afrique Occidentale Française, adressée à Monsieur le ministère des colonies, $9^{e}$ service, $1^{\text {er }}$ bureau, $1^{\text {er }}$ section, Paris, Dakar. Documentation Française, Notes et Documents 2801 (04), 3 p.

Bonte, P. (1967). L'Elevage et le Commerce de Bâetail dans l'Ader Douchi-Majya (Paris: C.N.R.S.).

Bonte, P. (2001). La Montagne de Fer. La SNIM (Mauritanie): Une Entreprise Minière Saharienne à l'Heure de la Mondialisation (Paris: Karthala).

Bonte, P. et Caludot-Hawad, H., dirs. (2000). Elites du monde nomade touareg et maure (Aix-en-Provence, France: Edisud).

Bourcade, Capitaine (Mai et Juin 1916). Agitation et opérations de police au pays touareg, par le commandant le détachement de Dori au sujet des opérations effectué contre les Touareg de l'Oudala. Documentation Française, Notes et Documents 2801 (6), 12 p.

Bourgeot, A. (1982). Production Pastorle et Pénétration Capitaliste: Anthropologie ou Sociologie? Revue TiersMonde 23 (90): 345-366.

Bourgeot, A. (1989). Le lion et la gazelle: Etats et Touaregs, Politique Africaine 34: 19-29.

Bourgeot, A. (1990). Le désert quadrillé: Des touaregs au Niger, Politique Africaine 38: 68-75.

Bourgeot, A. (1999). Horizons nomades en Afrique sahélienne: Sociétés, développement et démocratie (Paris: Karthala).

Boutraa, T. (2010). Growth Performance and Biomass Partitioning of the Desert Shrub Calotropis Procera under Water Stress Conditions, Research Journal of Agricultural and Biological Sciences 6 (1): 20-26.

Bovin, M. (2000). Pastoralists Manoeuvring in the Drought-Ridden Sahel, in Berner, B. and Trulsson, P., eds. Manoeuvering in an Environment of Uncertainty (Aldershot, England: Ashgate Press).

Breman, H. and De Wit, C.T. (1983). Rangeland Productivity and Exploitation in the Sahel, Science 221 (4618): 1341-1347.

Brevie, Gouverner Général de l'Afrique Occidentale Française (14 Novembre 1935). Construction du poste d'Aguelhok, n. 1529 C, Paris, adressée à Monsieur le ministère des colonies inspection générale des travaux publics - liaison aéronautique. Documentation Française, Notes et Documents 0526 (12), 9 p.

Briggs, L.C. (1960). Tribes of the Sahara (Cambridge: Harvard University Press).

Bryceson, D.F. (1996). Deagrarinization and Rural Development in Sub-Saharan Africa: A Sectoral Perspective, World Development 24 (1): 97-111.

Bryceson, D.F., Kay, C. and Mooij, J. eds. (2000). Disappearing Peasantries? Rural Labour in Africa, Asia and Latin America (London: Intermediate Technology Publications).

Buijtenhuijs, R. (2001). The Chadian Tubu: Contemporary Nomads Who Conquered a State, Africa 71 (1): 149161.

Burnham, P. (1996). The Politics of Cultural Difference in Northern Cameroon (London: International African Institute). 
Burr, M. and Collins, B.R. (1999). Africa's Thirty Years War: Libya, Chad, and the Sudan, 1963-1993 (Boulder, CO: Westview Press).

Calabrò, S., D’Urso, S., Banoin, M., Piccolo, V. and Infascelli, F. (2007). Nutritional Characteristics of Forages from Niger, Italian Journal of Animal Sciences 6 (1): 272-274.

Calvel, Le Gouverneur des Colonies (3 Juillet 1942). Rapport politique annuel, Année 1941 à Lieutenantgouverneur du Soudan Français, Koulouba, Colonie du Soudan Français. Documentation Française, Notes et Documents 0603 (9), 124 p.

Campbell, P. (1997). A note on growing season food habits of mountain gazelles and Nubian ibex in Saudi Arabia, Journal of Arid Environments 36: 705-709.

Carde, Le Gouverneur de général (29 Juin 1917). Affaire d'Agadès, adressée à Monsieur le ministère des colonies, Afrique Occidentale et Equatoriale - 1re section, Paris, n. 897. Documentation Française, Notes et Documents 2801 (6), 2 p.

Chander, G., Markham, B.L. and Helder, D.L. (2009). Summary of Current Radiometric Calibration Coefficients for Landsat MSS, TM, ETM+ and EO-1 Sensors, Remote Sensing of Environment 113: 893-903.

Chatty, D. and Colchester, M. (2002). Conservation and Mobile Indigenous Peoples: Displacement, Forced Settlement, and Sustainable Development (New York: Berghahn Books).

Chavez, P. (1996). Image-Based Atmosphere Corrections - Revisited and Improved, Photogrammetric Engineering and Remote Sensing 62: 1025-1036.

Chenoune, K. (2005). La flore et la végétation du Hoggar, Bois et Forets des Tropiques 284 (2): 79-83.

Childs, L. and Chelala, C. (1994). Drought, Rebellion and Social Change in Northern Mali, Cultural Survival Quarterly 17 (4): 16-19.

CILSS (Comite permanent Inter-états de Lutte contre la Sécheresse dans le Sahel) (Septembre 2006). Bulletin Mensuel (Niamey : Centre Régional AGRHYMET) M07/06. Also available at http://www.agrhymet.ne

CILSS (Comite permanent Inter-états de Lutte contre la Sécheresse dans le Sahel) (Juin/Juillet 2007). Bulletin Mensuel (Niamey : Centre Régional AGRHYMET) M04/07. Also available at http://www.agrhymet.ne

Cissé, S. (1981). "Sedentarization of Nomadic Pastoralists and 'Pastoralization' of Cultivators in Mali," in Galaty, J. ed., The Future of Pastoral Peoples (Ottawa: IDRC): 218-250.

Clanet, J.C. (1999). Stabilité du peuplement nomade au Sahel central, Sécheresse 10 (2): 93-103

Claudot-Hawad, H. (1990). Honneur et Politique: Les choix strategiques des Touaregs pendant la colonisation francaise, Revue du monde musulman et de la Méditerranée 57 (3): 11-48.

Claudot-Hawad, H. (1993). Les Touaregs : Portraits en fragments (Aix-en-Provence: Édisud).

Claudot-Hawad, H. (2001). Éperonner le monde: Nomadisme, cosmos et politique chez les Touaregs (Aix-enProvence: Édisud).

Clauzel, J. (1960). L'exploitation des salines de Taoudenni (Alger: Institut de Recherches Sahariennes).

Clauzel, J. (1962). Evolution de la vie économique et des structures sociales du pays nomade du Mali, de la conquête française à l'autonomie interne (1893-1958), Tiers-Monde 3 (9-10): 283-311.

Clozel, Lieutenant (7 Juin 1916). Dépêche Télégraphique Chiffrée, n. 1038, adressée à Colonies, Paris. Documentation Française, Notes et Documents 0518 (17), 3 p.

Conte, E. (1991). Herders, Hunters and Smiths: Mobile Populations in the History of Kanem, in Galaty, J.G. and Bonte, P. eds., Herders, Warriors and Traders (Boulder, CO: Westview Press): 221-247.

Coppin, P., Jonckheere, I., Nackaerts, K., Muys, B., and Lambin, E. (2004). Digital change detection methods in ecosystem monitoring: a review, International Journal of Remote Sensing 25 (9): 1565-1596.

Cortier, M. (1908). D'une Rive à l'autre du Sahara (Paris: Emile Rose).

Cour, J.M. (2001). The Sahel in West Africa: Countries in Transition to a Full Market Economy, Global Environmental Change 11: 31-47.

Cross, N. (1990). The Sahel: The Peoples' Right to Development, A Minority Rights Group Report, 28 p.

Davies, J. (2008). Turing the Tide: Enabling Sustainable Development for Africa's Mobile Pastoralists, Natural Resources Forum (32): 175-184.

De Bruijn, M. and Van Dijk, H. (2003). Changing Population Mobility in West Africa: Fulbe Pastoralists in Central and South Mali, African Affairs 102: 285-307.

De Chaffudeline, L. (1931). Famine de 1931 dans la colonie du Niger, adressée à Monsieur le Gouverneur General de l'Afrique Occidentale Française à Dakar. Documentation Française, Notes et Documents 2810 (13), 12 p.

De Jode, H., ed. (2010). Modern and Mobile: The Future of Livestock Production in Africa's Drylands, International Institute for Environment and Development, 88 p.

De Salins, Colonel (15 Juin 1912). Résumé Historique des événements militaires survenus aux colonies en 1910, 
Haut - Sénégal et Niger (Territoire Militaire du Niger, Farid. Documentation Française, Notes et Documents 2712 (1), 3 p.

De Verdière, C.P. (1995). Les Conséquences de la Sédératisation de l'Elevage au Sahel, Thèse Presentée pour l'obtention de titre de docteur de l'institut national agronomique (Paris: Grignon), $220 \mathrm{p}$.

Demangeot, J. et Bernus, E. (2001). Les Milieux Désertiques (Paris: Armand Colin).

Depierre, D. and Gillet, H. (1991). L'arbre désertique, Source de vie, Revue Bois et Forest des Tropiques 227 (1): 43-50.

Desalew, T. (2008). Assessment of Feed Resources and Rangeland Condition in Metema District of North Gondar Zone, Ethiopia, M.Sc. Thesis (Haramaya, Ethiopia: Haramaya University), 161 p.

Diatta S., Salifou, I., Sy, M.O., Kabouré-Zoungrana, C.Y., Banoin, M. and Akpo, L.E. (2008). Evaluation des potentialités germinatives d'un ligneux fourrager sahélien: Maerua crassifolia Forsk., Capparaceae, Livestock Research for Rural Development 20 (6): 87-96.

Dimpault, M. (10 Février 1923). Rapport fait par l'inspecteur de $3^{e}$ classe des colonies concernant la vérification du Chef de bataillon Fauche, d'infanterie coloniale, commandant provisoirement la région de Tombouctou, n. 100. Documentation Française, Notes et Documents 3054, 35 p.

Dobigeon, B. (1987). Sur une question controversée la périodicité des sècheresses sahéliennes (Etude de la pluviométrie à Gao-Mali), Cahier Géographiques de Rouen 28: 5-16.

Dorges B., Heucke, J., Dance, R. (2003). The Palatability of Central Australian Plant Species to Camels, Technote no. 116 (Darwin, Australia: Parks and Wildlife Commission of the Northern Territory), 8 p.

Du Bois, V.D. (1974). The Drought in Niger 15 (4-7): Washington, DC: American Universities Field Staff.

Dupire, P. (1962). Peuls Nomades (Paris: Karthala).

Duveyrier, H. (1864). Exploration du Sahara: Les Touareg du Nord (Paris: Challamel Ainé).

Eboué, T. (Mai 1935). Rapport politique annuel, Année 1934, à Lieutenant-gouverneur du Soudan Français, Colonie du Soudan Français, Documentation Française, Notes et Documents 2802 (4), 135 p.

Eckholm, E. and Brown, L.R. (1978). Spreading deserts - The hand of man, Bulletin of Atomic Scientists 34 (1): 10-16, 44-51.

Elfeel, A.A. (2010). Variability in Balanites aegyptiaca var. aegyptiaca seed kernel oil, protein and minerals contents between and within locations, Agricultural and Biology Journal of North America 1 (2): 170174.

Fairhead, J. and Leach, M. (1996). Misreading the African Landscape: Society and ecology in a forest-savanna mosaic (Cambridge: Cambridge University Press).

Fairhead, J. and Leach, M. (2000). Desiccation and Domination: Science and the Struggles over Environment and Development in Colonial Guinea, Journal of African History 41: 35-54.

Fanchette, S. (1999). Densité de Population et Intensification Agro-Pastorle en Haute-Casamance, Espace, Populations, Sociétés 1: 67-81.

Fensholt R., Rasmussen, K., Nielsen, T.T. and Mbow, C. (2009). Evaluation of earth observation based long term vegetation trends - Intercomparing NDVI time series trend analysis consistency of Sahel from AVHRR GIMMS, Terra MODIS and SPOT VGT data, Remote Sensing of Environment 113: 1886-1898.

FEWS (Famine Early Warning System) (August 2007). Good Agricultural Season is predicted with Good Rains throughout Niger, Food Security Update (Washington, DC: FEWS Network), 6 p. Also available at http://www.fews.net/niger .

Findley, S., Traore, S., Ouedraogo, D. and Diarra, S. (1995). Emigration from the Sahel, International Migration 33 (3-4): 469-483.

Fontès, J. et Guinko, S. (1993). Inventaire cartographique des ressources renouvelables du Burkina Faso par télédétection, Martin, L., dir., Télédétection et cartographie (Montréal: 1'Université du Québec): 227-238.

Foody, G.M. (2001). Monitoring the Magnitude of land-Cover Change around the Southern Limits of the Sahara, Photogrammetric Engineering and Remote Sensing 67 (7): 841-847.

Foody, G.M. and Boyd, D.S. (1999). Detection of partial land cover change associated with migration of inter-class transitional zones, International Journal of Remote Sensing 20 (14): 2723-2740.

Fousset, Lieutenant-gouverneur (22 Avril 1932). Année 1931, Rapport Politique Annuel, Gouvernement Soudan Français, à Koulouba. Documentation Française, Notes et Documents 0160, 89 p.

Frémeaux, J. (1993). La mise en place d'une administration aux marges sahariennes de l'O.A.F. (1891-1930), sous la direction de E. Bernus, P. Boilley, J. Clauzel et J-L, Triaud, Nomades et commandants (Paris: Karthala).

Friedl M.A., Woodcock, C., Gopal, S., Muchoney, D., Strahler, A.H. and Barker-Schaaf, C. (2000). A note on procedures used for accuracy assessment in land cover maps derived from AVHRR data, International 
Journal of Remote Sensing 21 (5): 1073-1077.

Gagnol, L. (2006). Les sociétés nomades sont-elles solubles dans la sédentarisation? Le contre-exemple des touaregs Kel Ewey (Ä̈r-Niger), l'Espace Géographique 4: 367-378.

Galaty, J.G. and Bonte, P., eds. (1991). Herders, Warriors and Traders: Pastoralism in Africa (Boulder, CO: Westview Press).

Gammer, M. (2000). Post-Soviet Central Asia and Post-Colonial Francophone Africa: Some Associations, Middle Eastern Studies 36 (2): 124-149.

Gebauer, J., El-Siddig, K. and Ebert, G. (2002). The potential of Under-utilized Fruit Trees in Central Sudan, Paper delivered at the Conference on International Agricultural Research for Development (Witzenhausen, Germany: University of Kassel-Witzenhausen), 6 p.

GITPA (Groupe International de Travail pour les Peuples Autochtones) (2007). Rapport Annuel (Sevres, France: International Work Group for Indigenous Affairs), $49 \mathrm{p}$.

Graham IV, F.C. (2010). What the Nigérien coup d'état means to the world, Review of African Political Economy 37 (126): 527-532.

Grégoire, E. (2000). Touaregs du Niger - Le destin d'un mythe (Paris: Karthala).

Grémont, C. (2005). Comment les Touaregs ont perdu le fleuve, Cormier-Salem, M-C., Juhé-Beaulaton, D., Boutrais, J. et Boussel, B., dirs., Patrimoines naturels au Sud (Paris: IRD): 237-290.

Gritzner, J.A. (1988). The West African Sahel: Human Agency and Environmental Change: Research Paper No. 226 (Chicago: University of Chicago).

Guichaoua, Y. (2009). Circumstantial Alliances and Loose Loyalties in Rebellion Making: The Case of the Tuareg Insurgency in Northern Niger, MICROCON Research Working Paper 20, $30 \mathrm{p}$.

Guinko, S. (1992). Etude phenologique des acacias du Burkina Faso et du Niger, Afrique de l'Ouest, Acta Biologica Benrodis 4: 153-161.

Gutelius, D. (2007). Islam in Northern Mali and the War on Terror, Journal of Contemporary African Studies 25 (1): 59-76.

Hama, B. (1967). Recherche sur l'histoire des touaregs sahariens et soudanais (Paris: Présence Africaine).

Hardin, G. (1968). The Tragedy of the Commons, Science 162: 1243-1248.

Harvey, D. (2008). On the Deep Relevance of a Certain Footnote in Marx's Capital, Human Geography 1 (2): 2629.

Hermann, S.M., Anyamba, A. and Tucker, C.J. (2005). Recent trends in vegetation dynamics in the African Sahel and their relationship to climate, Global Environmental Change 15: 394-404.

Hesse, C. and Thébaud, B. (2006). Will Pastoral Legislation Disempower Pastoralists in the Sahel? Indigenous Affairs 1 (6): 14-23.

Heumann B.W., Seaquist, J.W. Eklundh, L. and Jönsson, P. (2007). AVHRR derived phenological change in the Sahel and Soudan, Africa, 1985-2005, Remote Sensing of Environment 108: 385-392.

Hincker, C. (2005). Le sec et l'humide, appréciations touarègues des consistances alimentaires au Mali, Études Rurales 175-176: 183-194.

Hourst, Lieutenant (1898). French Enterprise in Africa, translated by Mrs. Arthur Bell (London: Chapman and Hall, Ltd.).

Hrany, H. (1917). Rapportage politique, $3^{e}$ Trimestre, pour le gouverneur en tournée le Secrétaire General charge de l'expédition des affaires. Documentation Française, Notes et Documents 0534 (1), 7 p.

Hulme, M. (2001). Climatic perspectives on Sahelian desiccation: 1973-1998, Global Environmental Change 11: 19-29.

IAEA (International Atomic Energy Agency) (2005). Radiological Conditions at the Former French Nuclear Test Sites in Algeria (Vienna: United Nations), $71 \mathrm{p}$.

Ibrahim, S (2006). Plan Triennal 2007-2009 de la Commune Rural de Ménaka (Gao: République du Mali).

Ilkjaer, L. and Boureima, S.S. (2010). A model for developing performance indicators in Niger, International Journal of Police Science and Management 12 (2): 195-205.

IWGIA (International Work Group for Indigenous Affairs) (2006). Indigenous Peoples of Africa: The Forgotten Peoples? (Copenhagen: African Commission on Human and Peoples Rights), 29 p.

Jacks, B. (1994). Living Conditions and Nutrition of Some Tamasheq Groups in Mali under the Influence of Drought, Ambio 23 (7): pp. 438-445.

Jafari, R., Lewis, M.M., and Ostendorf, B. (2007). Evaluation of Vegetation Indices for Assessing Vegetation Cover in the Southern Arid Lands in South Australia, The Rangeland Journal 29 (1): 39-49.

Javzandulam T., Tateishi, R. and Sanjaa T. (2005). Analysis of vegetation indices for monitoring vegetation degradation in semi-arid and arid areas of Mongolia, International Journal of Environmental Studies 62 
(2): 215-225.

Jourde, C. (2007). Constructing representations of the 'Global War on Terror' in the Islamic Republic of Mauritania, Journal of Contemporary African Studies 25 (1): 77-100.

Kahn, J.S. and Llobera, J.R. eds. (1981). The Anthropology of Pre-Capitalist Societies (Atlantic Highlands, NJ: Humanities Press).

Keenan, J. (2009). Al-Qaeda terrorism in the Sahara? Anthropology Today 25 (4): 14-18.

Keita, K. (1998). Conflict and Conflict Resolution in the Sahel (Strategic Studies Institute), 46 p.

Kim T.R., Pastuszyn, A., Vanderjagt, D.J., Glew, R.S., Millson, M. and Glew R.H. (1997). The Nutritional Composition of Seeds from Boscia senegalensis (Dilo) from the Republic of Niger, Journal of Food Composition and Analysis 10: 73-81.

Krings, T. (1995). Marginalisation and Revolt Among the Tuareg in Mali and Niger, GeoJournal 36 (1): $57-63$.

Krogh, L. and Paarup-Laursen, B. (1997). Indigenous soil knowledge among the Fulani of northern Burkina Faso: linking soil science and anthropology in analysis of natural resource management, GeoJournal 43: 189197.

Kumar, M. and Bhandari, M.M. (1993). Impact of Human Activities on the Pattern and Process of Sand Dune Vegetation in the Rajasthan Desert, Desertification Control Bulletin 22: 45-54.

Lambin E.F., Goyvaerts, K. and Petit, C. (2003). Remotely-sensed indicators of burning efficiency of savannah and forest fires, International Journal of Remote Sensing 24 (15): 3105-3118.

Le Houérou, H.N. (1977). The Nature and Causes of Desertification, in M.H. Glantz, ed., Desertification (Boulder, CO: Westview): 17-38.

Le Rouvreur, A. (1962). Sahéliens et Sahariens du Tchad (Paris: Berger-Levrault).

Lecocq, B. (2004). Unemployed Intellectuals in the Sahara: The Teshumara Nationalist Movement and the Revolutions in Tuareg Society, International Review of Social History (49): 87-109.

Lecocq, B. and Schrijver, P. (2007). The War on Terror in a Haze of Dust: Potholes and Pitfalls on the Saharan Front, Journal of Contemporary African Studies 25 (1): 141-166.

Little, P.D. (1996). Pastoralism, Biodiversity and the Shaping of Savanna Landscapes in East Africa, Africa 66 (1): 37-50.

Lovejoy, P.E. (1978). The Borno Salt Industry, International Journal of African Historical Studies 11 (4): 629668.

Lozeray (1937). Rapport de la sous-commission chargée d'une enquête en A.O.F., IV, L'Enseignement, Commission de l'Algérie, Des Colonies, Des Protectorats, Documentation Française, Notes et Documents 0513 (12), 7 p.

Lupo F., Reginster, I. and Lambin, E.F. (2001). Monitoring land-cover changes in West Africa with SPOT Vegetation: impact of natural disasters in 1998-1999, International Journal of Remote Sensing 22 (13): 2633-2639.

Lutaud, C.H. (1917). Le gouverneur général de l'Algérie, Alger, adressée à Monsieur le ministère de la guerre, Paris, le 16 juillet, Documentation Française, Notes et Documents 0526 (01), 4 p.

Lykke A.M., Fog, B. and Madsen, J.E. (1999). Woody vegetation changes in the Sahel of Burkina Faso assessed by means of local knowledge, aerial photos, and botanical investigations, Geografisk Tidsskrift 2: 57-68.

MacDonald, L. H. (1986). Natural Resources Development in the Sahel: The Role of the United Nations System (Tokyo: United Nations University Press).

MacEwen, L. (2010). Voluntary repatriation and the participation of Mauritanian refugees, Forced Migration Review 33: 72-74.

MacMillan, K. and Koenig, T. (2004). The Wow Factor: Preconceptions and Expectations for Data Analysis Software in Qualitative Research, Social Science Computer Review 22 (2): 179-186.

Maiga, A., De Leeuw, P.N., Diarra, L. and Hiernaux, P. (1991). The Harvesting of Wild-Growing Grain Crops in the Gourma Region of Mali, International Institute for Environment and Development Paper, no, 27 (London: Dryland Networks Programme), 11 p.

Malkki, L. (1992). National Geographic: The rooting of peoples and territorialization of national identity among scholars and refugees, Cultural Anthropology 7: 24-44.

Martin, Lieutenant-Colonel (21 Septembre 1926). Note pour Monsieur le Gouverneur General, Dakar. Documentation Française, Notes et Documents 2802 (07), 2 p.

Marty, A. (1999). La division sédentaires - nomades. Le cas de la boucle du Niger au début de la période coloniale, sous la direction d'Holtedahl, L., Gerrard, S., Njeuma, M., et Boutrais, J., Le pouvoir du savoir de l'arctique aux tropiques (Paris: Karthala) : 289-306.

McPeak, J.G., (2001). Analyzing and Addressing Localized Degradation of the Commons (Ithaca: Cornell 
University, Unpublished Thesis).

Milewski A.V. and Madden, D. (2006). Interactions between large African browsers and thorny Acacia on a wildlife ranch in Kenya, African Journal of Ecology 44: 515-522.

Milich L. and Weiss, E. (2000). GAC NDVI images: relationship to rainfall and potential evaporation in the grazing lands of The Gourma (northern Sahel) and in the croplands of the Niger-Nigeria border (southern Sahel), International Journal of Remote Sensing 21 (2): 261-280.

Moleele N., Ringrose, S., Arnberg, W., Lunden, B. and Vanderpost, C. (2001). Assessment of vegetation indexes useful for browse (forage) prediction in semi-arid rangelands, International Journal of Remote Sensing 22 (5): 741-756.

Montes C.S., da Silva, D.A., Garcia, R.A., de Muñiz, G.I.B. and Weber, J.C. (2010). Calorific value of Prosopis Africana and Balanites aegyptiaca wood: relationships with tree growth, wood density and rainfall gradients in the West African Sahel, Biomass and Bioenergy (in press).

Moran, M.S., Jackson, R.D., Slater, P.N. and Teillet, P.M. (1992). Evaluations of the simplified procedures for retrieval of land surface reflectance factors from satellite sensor output, Remote Sensing of Environment 41: 169-184.

Moreira, E.P. and Bayraktar, N. (2008). Foreign Aid, Growth and Poverty: A Policy Framework for Niger, Journal of Policy Making 30: 523-539.

Mortimore, M.J. and Adams, M.W. (2001). Farmer adaptation, change and \& 'crisis' in the Sahel, Global Environmental Change 11: 49-57.

Müller M.M.L, Guimarães, M.F., Desjardins, T. and Mitja, D. (2004). The relationship between pasture degradation and soil properties in the Brazilian amazon: a case study, Agriculture, Ecosystems and Environment 103: 279-288.

Mundy, J.A (2007). Performing the Nation, pre-figuring the state: The Western Saharan refugees thirty years later, Journal of Modern African Studies 45 (2): 275-297.

Naseef, M., Anderson, S. and Hesse, C. (2009). Pastoralism and Climate Change: Enabling Adaptive Capacity, Regional Pastoral Livelihoods Project (London: Oxfam), 26 p.

Neefjes, K. (2000). Environments and Livelihoods: Strategies for Sustainability (London: Oxfam).

Ngaido, T. (1993). Land Use and Conflicts in Western Rural Niger: Kollo and Tillabery Arrondissemets (Madison: University of Wisconsin-Madison Press, Discussion Paper).

Nicholas, F. (1950). Tamesna: Les Ioullemmeden de l'Est (Paris: Imprimerie Nationale).

Nicholson, S. (2005). On the question of the "recovery" of the rains in the West African Sahel, Journal of Arid Environments 63: 615-641.

Nicolaisen, J. (1963). Ecology and Culture of the Pastoral Tuareg, with Particular Reference to the Tuareg of Ahaggar and Ayr (Copenhagen: National Museum).

Nnoli, O. (1989). Desertification, Refugees and Regional Conflicts in West Africa, in Af Orñas, A.H. and Salih, M.A.M., eds., Ecology and Politics (Uppsala: Scandanavian Institute of African Studies): 169-180.

Noel J.C., Saad, Z.A. and Bunderson, W.T. (2003). Approaches, Issues and Lessons Learned - The Evolution of a Management Approach, Planning for Agroforestry Research in Western Sudan (2003): 203-226.

Noureddine N-E., Amrani, S. and Aïd, F. (2010). Statut symbiotique et souches de rhizobia associées à l'Acacia tortilis subsp. Raddiana [Acacia raddiana s.s.], mimosö̈dée des régions désertiques de l'Algérie, Botanique 88: 39-53.

Olivier de Sardan, J-P. (1984). Les sociétés songhay-zarma (Niger-Mali) : Chefs, guerriers, esclaves, paysans (Paris: Karthala).

Olsson, L., Eklundh. L. and Ardö, J. (2005). A recent greening of the Sahel-trends, patterns and potential causes, Journal of Arid Environments 63: 556-566.

Osuga I.M., Wambui C.C., Abdulrazak, S.A., Ichinohe, T. and Fujihara, T. (2008). Evaluation of nutritive value and palatability by goats and sheep of selected browse foliages from semiarid are of Kenya, Animal Science Journal 79: 5832-589.

Otterman, J. (1974). Baring High-Albedo Soils by Overgrazing: A Hypothesized Desertification Mechanism, Science 186: 531-33.

Ouédraogo E., Mando, A. and Brussard, L. (2006). Soil macrofauna affect crop nitrogen and water use efficiencies in semi-arid West Africa, European Journal of Soil Biology 42: S275-S277.

Ould Cheikh, A.W. (1990). Pastoral Production Decline and Recovery in Mauritania, 1970-1990, in Atmara, H.A. and Founou-Tchuigoua, B. eds. African Agriculture (London: Zed Books): 90-111.

Ould Cheikh, A.W. (1991). Herders, Traders and Clerics: The Impact of Trade. Religion and Warfare on the Evolution of Moorish Society, in Galaty, J.G. and Bonte, P. eds., Herders, Warriors and Traders 
(Boulder, CO: Westview Press): 199-218.

Ousman, A. (2004). The Potential of Islamist Terrorism in Sub-Saharan Africa, International Journal of Politics, Culture and Society 18 (1): 65-105.

Oxby, C. (1985). Settlement schemes for herders in the subhumid tropics of West Africa; Issues of land rights and ethnicity, Pastoral Development Network Paper 19f (London: Overseas Development Institute), 19 p.

Pereira G.F., de Araújo, G.G.L., de Medeiros, A.N., Lima, G.F. da C., Gracindo, A.P.A.C., de Lima Júnior, V., Fernandes Júnior, F.C. and Cândido, E.P. (2010). Intake and digestibility of flor-de-seda hay in diets of dairy goats, Revista Brasileira de Saúde e Produção Animal 11 (1): 79-90.

Painter, T., Sunberg, J. and Price, T. (1994). Your Terroir and My 'Action Space': Implications of Differentiation, Mobility and Diversification for the Approache Terroir in Sahelian West Africa, ” Africa 64 (4): 447-464.

Pandolfi, P. (1998). Les Touaregs de l'Ahaggar, Saharan Algérien : parenté et résidence chez les Dag-Ghali (Paris : Karthala).

Pedersen, J. (1995). Drought, Migration and Population Growth in the Sahel, Population Studies 49 (1): $111-126$.

Pelican, M. (2009). Complexities of the Indigeneity and Autochtonony: An African Example, American Ethnologist 36 (1): 52-65.

Petit, C.C. and Lambin, E.F. (2001). Integration of multi-source remote sensing data for land cover change detection, International Journal of Geographical Information Science 15 (8): 785-803.

Pliez, O. (2006). Nomades d'hier, nomades d'aujourd'hui: les migrants africaines réactivent-ils les territoires nomades au Sahara? Annales de Géographie 652: 688-707.

Poitou, D. (1982). Arlit, Ville Pionnière de l'industrialisation nigérienne, Afrique et l'Asie Modernes, 29 (2): $29-47$.

Polgreen, L. (14 December 2008). "Battle in a Poor Land for Riches beneath the Soil," New York Times. Available at http://www.nytimes.com/2008/12/15/world/africa/15niger.html?_r=1\&hp.

Porter, G. (1995). Adapting to environment and market: trade and marketing in northern Nigeria, in Binns, T. ed., People and the Environment in Africa (New York: John Wiley and Sons): 197-204.

Prashad, V. (2009). Fighting a Proxy War for America? New African 12: 46-47.

PROHUZA (Centre d'Etudes et d'Information des Problèmes Humaines des les Zones Arides) (1960). Le Mekhadma: étude sur l'évolution d'un groupe humain dans le Sahara moderne (Paris: Arts et Métiers Graphiques), $223 \mathrm{p}$.

Prothero, R.M. (1994). Forced Movements of Population and Health Hazards in Tropical Africa, International Journal of Epidemiology 23 (4): 657-664.

Rabeil, T., Newby, J. and Hama, A. (2007). Conservation of Termit and Tin Toumma (Niger) (Annual report for the Sahara Conservation Fund), 30 p.

Randall, S. (2005). The Demographic Consequences of Conflict, Exile and Repatriation: A Case Study of Malian Tuareg, European Journal of Population 21: 291-320.

Raynaud, J. (1948). Rapport d'enquête administrative relative à certain trafic de bovidés/trafic des tissus. Documentation Française, Notes et Documents 2188, 56 p.

Raynaut, C. (2001). Societies and Nature in the Sahel: Ecological Diversity and Social Dynamics, Global Environmental Change 11: 9-18.

Reporters without Borders (31 October 2007). "Newspaper Editor Charged with Criminal Association, transferred to Agadez Prison.” Available at: http://en.rsf.org/niger-newspaper-editor-charged-with-31-10-2007, 23927.html.

Reporters without Borders (15 January 2008). “Appeal Court Defers Decision on Legality of Phone Taps in Moussa Kaka Case Until February 12." Available at: http://en.rsf.org/spip.php?page=recherche\&lang=en\&

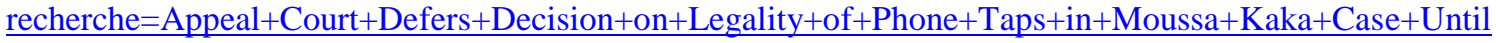
+ February+12+\&image. $\mathrm{x}=50$ \&image. $\mathrm{y}=14$.

République Française (2007). Dossier de présentation des essaies nucléaires et leur suivi au Sahara, Délégation a l'information et a la Communication de la Défense (Paris: Ministère de le Défense), 28 p.

Retaillé, D. (1993). Afrique : le besoin de parler autrement qu'en surface. Espaces Temps 51-52: 52-62.

Retaillé, D. (1998). L'espace nomade, Revue de géographie de Lyon 73 (1): 71-82.

Richer, A. (1924). Les Oulliminden (Paris: Emile Larose).

Rodd, F., Rodd, P. and Courtald, A. (1929). A Second Journey among the Southern Tuareg, The Geographical Journal 73: 1-15.

Sahara Focus (2009). Future of the Sahara: What choice is left for the Tuareg? Menas Sahara Focus 5 (4): 1-13.

Salifou, A. (1973). Les Francais, Fihroun et les Kounta, 1902-1916, Journal de la Société des Africanistes 43 (2): 175-195.

Salvy, G., Barthé, A., Laboubée, J., Berre, H., Gaillard, M., Delon, M., Beyries, J. et Coudry, A. (1951). 
L'Economie Pastorale Saharienne. Documentation Française, Notes et Documents 8201, 65 p.

San Martín, P. (2004). Western Sahara: Road to Perdition? African Affairs 103 (413): 651-660.

Sayare, S. (26 July 2010). "North African Militants Kill Frenchman, 78," The New York Times. Available at http://www.nytimes.com/2010/07/27/world/europe/27france.html?_r=1.

Scoones, I. and Wolmer, W. eds. (2002). Pathways of Change for Africa: Crops, Livestock and Livelihoods in Mali, Ethiopia and Zimbabwe (Oxford: James Currey).

Sèbe, B. (2010). In the Shadow of the Algerian War: The United States and the Common Organization of Saharan Regions (OCRS), 1957-1962, The Journal of Imperial and Commonwealth History 38 (2): 303-322.

Sehmer, A. and Welsh, M. (15 July 2008). "Niger's Nomads Fight for Rights,” Aljazeera. Available at http://english.aljazeera.net/focus/unrestsahara/2008/07/2008710121834923863.html.

Seely, J.C. (2001). A Political Analysis of Decentralization: Coopting the Tuareg Threat in Mali, Journal of Modern African Studies 39 (3): 499-524.

Serneels, S., Said, M. and Lambin, E.F. (2001). Land-cover changes around a major East African wildife reserve: the Mara ecosystem, International Journal of Remote Snesing 22: 3397-3420.

Shaltout, K.H., Sheded, M.G. and Salem, A.I. (2010). Vegetation spatial heterogeneity in a hyper arid Biosphere Reserve area in North Africa, Acta Botanica Croatica 69 (1): 31-46.

Sharma, K.D., Singh, S., Singh, N. and Bohra, D.N. (1989). Satellite Remote Sensing for Detecting the Temporal Changes in the Grazing Lands, Journal of the Indian Society of remote Sensing 17 (4): 55-59.

Shipton, P. (1990). African Famines and Food Security: Anthropological Perspectives, Annual Review of Anthropology 9: 353-394.

Silva, M.C.C., da Silva, A.B., Teixeira, F.M., de Sousa, P.C.P., Rondon, R.M.M., Honório Júnior, J.E.R., Sampaio, L.R.L., Oliveira, S.L., Holonda, A.N.M., de Vasconcelos, S.M.M. (2010). Therapeutic and biological activities of Calotropis procera (Ait.) R. Br., Asian Pacific Journal of Tropical Medicine 2010: 332-336.

Simon, H. (28 Février 1919). Le ministère des colonies, adressée à Monsieur le gouverneur général de l'Afrique Occidentale Française, Paris, no. 42.. Documentation Française, Notes et Documents 0518 (20), 10 p.

Singh, K., Hundal, H.S., Singh, D. and Boora, R.S. (2010). Monitoring Nutrient Status of Ber (Zizyphus mauritania) Fruit Trees in Semi-arid and Arid Regions of Northwest India through Diagnostic Recommendation and Integrated System Approach, Communication in Soil Science and Plant Analysis 41 (17): 2011-2021.

Sivakumar, M.V.K. (1991). Drought Spells and Drought Frequencies in West Africa (Patancheru, India: International Crops Research Institute).

Smith, A.B. (2005). African Herders (Walnut Creek, CA: Alta Mira Press).

Smith, J. (13 January 2009). 'Niger's Leader Suspects ‘Bandits' Seized Envoys,' Tronto Star. Available at http://www.allvoices.com/news/2241859/s/26797525-niger-president-says-un-envoy-kidnapped-by-rebels.

SNV-Mali (2006). Pastoralisme Transfrontalier du Mali et Niger (Bamako: Document de Travail), 62 p.

Solé-Arqués, R. (2009). "Chad: Internal Power Struggles and Regional Humanitarian Crisis," Humanitarian Response Index 2008 (New York: Palgrave): 150-158.

Some, A.N., Traoré, K., Traoré, O., Tassembedo, M. (2007). Potentiel des jachères artificielles à Andropogon spp. dans l'amélioration des propriétés chimiques et biologiques des sols en zone soudanienne (Burkina Faso), Biotechnologie, Agronomie, et Société Environnementale 11 (3): 245-252.

Spittler, G. (1993). Les Touaregs face aux sécheresses et aux famines. Les Kelewey de l'Aïr (Niger) (19001985) (Paris: Karthala).

Starr, M.A. (1987). Risk, Environmental Variability and Drought-Induced Impoverishment: The Pastoral Economy of Central Niger, Africa 57 (1): pp. 29-50.

Taia, W.K. (2009). General View of Malvaceae Juss. S.L. and Taxonomic Revision of Genus Abutilon Mill. in Saudi Arabia, Journal of King Abdulaziz University Science 21 (2): 349-363.

Teuasson, Lieutenant-gouverneur (29 Février 1924). Année 1923, Rapport Politique Annuel, Gouvernement Soudan Français, à Koulouba. Documentation Française, Notes et Documents 0160, 58 p.

Teuasson, Lieutenant-gouverneur (20 Février 1926). Année 1924, Rapport Politique Annuel, Gouvernement Soudan Français, à Koulouba. Documentation Française, Notes et Documents 0160, 65 p.

Teuasson, Lieutenant-gouverneur (10 Février 1927). Année 1926, Rapport Politique Annuel, Gouvernement Soudan Français, à Koulouba. Documentation Française, Notes et Documents 0160, 83 p.

Teuasson, Lieutenant-gouverneur (8 Mars 1929). Année 1928, Rapport Politique Annuel, Gouvernement Soudan Français, à Koulouba. Documentation Française, Notes et Documents 0160, 79 p.

Teuasson, Lieutenant-gouverneur (8 Mars 1930). Année 1929, Rapport Politique Annuel, Gouvernement Soudan Français, à Koulouba. Documentation Française, Notes et Documents 0160, 62 p.

Thébaud, B. (2002). Foncier pastoral et gestion de l'espace au Sahel (Paris: Karthala). 
Thiam, A.K. (2003). The Causes and Spatial pattern of land Degradation Risk in Southern Mauritania using Multitemporal AVHRR-NDVI Imagery and Field Data, Land Degradation and Development 14: 133-142.

Thurston, A. (2010). Counterterrorism and Democracy Promotion in the Sahel under Presidents George W. Bush and Barack Obama from September 11, 2001, the Nigerien Coup of February 2010, Concerned African Scholars 85: 50-62.

Timberlake, L. (1985). The Sahel: Drought, Desertification and Famine, Draper Fund Report 14: 17-25.

Triaud, J-L. (1993). Un mauvais départ: 1920, l'Ä̈r en Ruines, Bernus, E., Boilley, J., Clauzel , J. et Triaud, J-L., dirs., Nomades et commandants (Paris: Karthala).

Triaud, J-L. (1996). Les 'trous de mémoire' dans l'histoire africaine le Sanusiyya au Tchad: Le case du Ouaddai, Revue Française d'Histoire d'Outre-mer 83 (2): 5-23.

Turner, M.D. (1999). Labor Process and the Environment: The Effects of Labor Availability and Compensation on the Quality of Herding in the Sahel, Human Ecology 27 (2): 267-296.

Turner, M.D. (2000). Drought, Domestic Budgeting and Wealth Distribution in Sahelian Households, Development and Change 31 (5): pp. 1009-1035.

Turner, M.D. (2003). Methodological Reflections on the Use of Remote Sensing and Geographic Information Science in Human Ecological Research, Human Ecology 31 (2): 255-279.

Turner, M.D. and Hiernaux, P. (2008). Changing Access to Labor, Pastures, and Knowledge: The Extensification of Grazing Management in Sudano-Sahelian West Africa, Human Ecology 36: 59-80.

Turner, M.D. and Williams, T.O. (2002). Livestock Market Dynamics and Local Vulnerabilities in the Sahel, World Development 30 (4): 683-705.

Twumasi Y.A. and Merem, E.C. (2007). Using Remote Sensing and GIS in the Analysis of Ecosystem Decline along the River Niger Basin: The Case of Mali and Niger, International Journal of Environmental Research and Public Health 4 (2): 173-184.

United Nations (1986). République du Tchad: Rapport de mission sur l'évaluation des besoins d'aide en matière de population. Fonds des Nations Unis (New York), 51 p.

Vallet, M. (1990). Les Touaregs du Hoggar entre décolonisation et indépendances (1954-1974), Revue du Monde Musulman et de la Méditerranée 57 (3): 77-90.

Vedeld, T. (1996). Enabling Local Institutional Building: Reinventing or Enclosing the Commons of the Sahel? in Marcussen, H. ed., Improved Natural Resources Management, Occasional Paper no. 17 (IDS: Roskilde University): 135-189.

Vincke C., Diédhiou, I., Grouzis, M. (2010). Long term dynamics and structure of woody vegetation in the Ferlo (Senegal), Journal of Arid Environments 74: 268-276.

Von Maydell, H-J. (1983). Arbres et Arbustes du Sahel (Roßdorf, Germany: Gesellschaft für Technische Zusammenarbeit).

Wade, N. (1974). Sahelian Drought: No Victory for Western Aid, Science 185: 234-237.

Walker, D. (2005). FROLINAT's “Muslim” Insurgency in Chad: 1965-1975, Journal of the Pakistan Historical Society 53 (3): 7-35.

Walther, O. (2009). A Mobile Idea of Space. Traders, Patrons and the Cross-Border Economy in Sahelian Africa, Journal of Borderland Studies 24 (1): 34-46.

Walther, O. and Retaillé, D. (2010). Sahara or Sahel? The fuzzy geography of terrorism in West Africa, CEPS/ INSTEAD Working Paper No. 2010-35, 17 p.

Walton, L. (2003). The effects of fire of various intensities of plant regeneration in the arid zone environment, central Australia, Paper written for the Heaslip Arid Zone Research Scholarship (Alice Springs: Central Land Management Association), 9 p.

Walton, L. and Walsh, D. (2004). Plant Recovery after Fires of Different Intensities: Some Observations from Central Australia, Range Management Newsletter 4 (1): 6-10.

Watts, M. (1987). Drought, Environment and Food Security: Some Reflections on Peasants, Pastoralists and Commoditization in Dryland West Africa, in M.J. Glantz, ed., Drought and Hunger in Africa (Cambridge: Cambridge University Press): 171-211.

Yadang, G., Tchatchueng, J-B. and Tchiégang, C. (2009). Protein, Carbohydrate, Fat and Energy Content of "Ready-to-Eat Foods" in Cameroonian Sahel's Region, Journal of Food Technology 7 (1): 1-4.

Zuelch, T. (12 April 2010). Libyan Arab Jamahiriya (Göttigen, Germany: Society for Threatened Peoples), 2 p. Available at: http://lib.ohchr.org/HRBodies/UPR/Documents/ Session9/LY/STP_SocietyforThreatened Peoples.pdf. 